UNIVERSIDADE DE SÃO PAULO

FACULDADE DE FILOSOFIA CIÊNCIAS E LETRAS DE RIBEIRÃO PRETO

\title{
Desenvolvimento de uma fonte luminosa baseada em lâmpadas halógenas para aplicações na fotobiologia e fotomedicina.
}

WAGNER FONZI

Ribeirão Preto 
WAGNER FONZI

Desenvolvimento de uma fonte luminosa baseada em lâmpadas halógenas para aplicações na fotobiologia e fotomedicina.

Dissertação apresentada ao Programa de PósGraduação da Faculdade de Filosofia Ciências e Letras de Ribeirão Preto da Universidade de São Paulo para obtenção do título de Mestre em Física Aplicada á Medicina e a Biologia.

Área de concentraçâo: Física.

Orientador: Prof. Dr. louri Borissevitch. 


\begin{abstract}
AUTORIZO A REPRODUÇÃO E DIVULGAÇÃO TOTAL OU PARCIAL DESTE TRABALHO, POR QUALQUER MEIO CONVENCIONAL OU ELETRÔNICO, PARA FINS DE ESTUDO E PESQUISA DESDE QUE CITADA A FONTE.
\end{abstract}

FICHA CATALOGRÁFICA

Fonzi, Wagner

Desenvolvimento de uma fonte luminosa baseada em lâmpadas halógenas para aplicações na fotobiologia e fotomedicina. Ribeirão Preto, 2008.

99 p. : il. ; $30 \mathrm{~cm}$

Tese de Mestrado, apresentada à Faculdade de Filosofia Ciências e Letras de Ribeirão Preto/USP. Área de concentração: Física Aplicada a Medicina e a Biologia.

Orientador: Borissevitch, louri.

1. Fotoquimeoterapia. 2. Fonte de luz halógena. 3. Terapia Fotodinâmica. 


\section{Folha de Aprovação}

Wagner Fonzi.

Desenvolvimento de uma fonte luminosa baseada em lâmpadas halógenas para aplicações na fotobiologia e fotomedicina.

Dissertação apresentada ao Programa de PósGraduação da Faculdade de Filosofia Ciências e Letras de Ribeirão Preto da Universidade de São Paulo para obtenção do título de Mestre em Física Aplicada á Medicina e a Biologia. 


\section{Dedicatória}

Aos meus pais Celso e Avani, por todo apoio e incentivo dado ao longo de todos anos de estudo, pois sem este apoio eu não estaria aqui.

A minha madrinha Senise, por estar sempre presente, mesmo que distante.

Ao meu orientador Prof. Dr. louri Borissevitch, pelo apoio, paciência e amizade e na dedicação na orientação deste trabalho.

A minha namorada Amanda que esteve presente em todos os momentos felizes, difíceis e decisivos. 


\section{Agradecimentos}

Aos colegas de laboratório: Cássia, Ernando, Fábio, Luciana, Marina, Moíses, Pablo e Fábio, pelo auxílio e pela amizade.

Aos funcionários José Luis Aziani, Elcio Aparecido Navas e Leonardo Martins de Oliveira, técnicos em laboratório, pelo auxílio, coloaboração e amizade.

À Luciana pela amizade e pela colaboração nos testes invitro.

Aos amigos da graduação, alguns já da pós-graduação, pelo apoio e pela amizade.

À Capes pela concessão da bolsa de mestrado. 


\section{Resumo}

Este projeto teve como finalidade construir uma fonte de luz baseada em lâmpadas halógenas que apresentasse características técnicas adequadas para aplicações em fotobiologia e fotomedicina, versátil e comercialmente viável. Foram analisadas as características de diferentes lâmpadas halógenas e realizados os experimentos com duas lâmpadas escolhidas, das quais utilizamos a lâmpada de menor divergência luminosa. Foi analisado também o material do corpo da fonte, com relação a características de aquecimento e peso, sendo escolhido um corpo de alumínio produzido industrialmente. Foram avaliadas as características ópticas das lentes, sendo escolhidas as lentes de vidro utilizadas em retroprojetores. Foram analisados os materiais e a construção de filtros térmicos para diminuir o aquecimento do objeto sob irradiação, sendo que escolhemos construir um filtro térmico próprio, que utiliza a água como absorvedor de calor. Medimos e avaliamos as características: espectrais, térmicas, a potência radiante (irradiância) e sua distribuição espacial de três protótipos, onde cada um recebeu modificações de modo a torná-los mais adequados para aplicações na fotoquimeoterapia. Foram também realizados testes preliminares de fotocitotoxicidade do protótipo final com o composto fotossensibilizador de nome comercial Photogem® aplicado em células tumorais de adenocarcinoma de colo retal humano (HT29), cujo resultado foi a ativação do composto fotossensibilizador e indução da morte celular.

Palavras-chave: fotobiologia, fotomedicina, fonte de luz, lâmpadas halógenas. 


\section{Abstract}

The aim of this work was to produce a light source based in halogen lamps. This source should have appropriated technical characteristic for application in photobiology and photomedicine, it has easy operation and be commercially viable. The characteristics of different halogen lamps were evaluated and the lamp of smaller luminous divergence was chosen. We also have evaluated the material of the source holder, especially heating characteristics and weight; finally we chose an aluminum holder. Then, the lenses optical characteristics were studied, and we decided that the glass lenses used in projectors were the best. The materials and the construction of thermal filters were evaluated in order to reduce the heating of the object under irradiation, and we preferred to construct a thermal filter, that uses water as an heat absorber. The spectral and thermal characteristics, the radiant power (irradiance) and its space distribution of three prototypes were measured and evaluated, each one received modifications to become more appropriated to applications in photochemotherapy. We also made preliminaries tests of photocytotoxicity and the final prototype was used with the photosensitizer (Photogem $\AA$ ) in human colon carcinoma cell lines HT-29, resulting in the photosensitizer activation, that induced cellular death.

Key-words: photobiology, photomedicine, light source, halogen lamps. 


\section{Lista de Figuras}

Figura 1. Diagrama energético reações do tipo I e II (Foote,1991)........................ 15

Figura 2. Profundidade da penetração da energia luminosa dentro de tecidos biológicos em função do comprimento de onda (Scientific American, 2003)

Figura 3. a. Esquema da lâmpada incandescente. b. lâmpada incandescente c. lâmpada halógena. (PucRio, 2008). 24

Figura 4. a. Equação Planck (Rutgers, 2008). b. Exemplo em diferentes temperaturas (Souza, 2001) .................................................................... 25

Figura 5. Curvas de distribuição luminosa das lâmpads (Osram, 2008)............... 29

Figura 6. Ilustração da Interface do TRM com o PDP (Neto, 2005)....................... 33

Figura 7. Tipos de Technology Roadmapping e exemplos (Phaal, 2001)............ 34

Figura 8. Medidor Spectra Physics 407A..................................................... 38

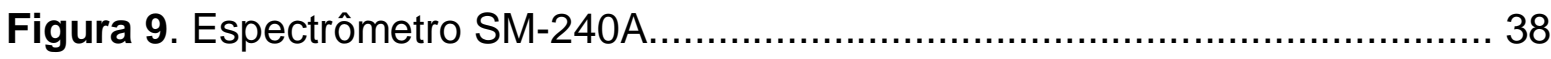

Figura 10. Espectrômetro Beckman Coulter DU640.......................................... 39

Figura 11. Sistema XY com Spectra Physics 407A …................................... 40

Figura 12. Irradiação solar (Martins et al, 2004) ................................................ 41

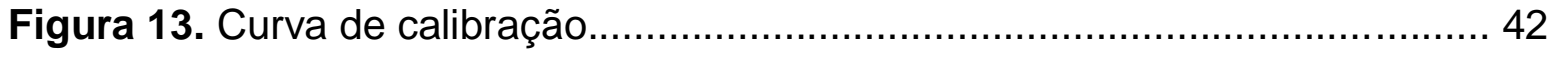

Figura 14. Espectros de emissão da lâmpada 1 ............................................... 48

Figura 15. Espectros de emissão lâmpada 2 .................................................. 48

Figura 16. Irradiância x distância lâmpada $1(\mathrm{~A})$ e 2(B) ........................................ 49

Figura 17. Irradiância x distância lâmpada 2 com lente......................................... 50

Figura 18. Espectro de transmitância do filtro de vidro e do filtro de água............ 53

Figura 19. Irradiância x distância lâmpada 2 ..................................................... 55

Figura 20. Espectro da emissão $N(\lambda)$ da lâmpada 2 sem e com filtros térmicos. 
Figura 21. Esquema geométrico com lâmpada 2............................................ 58

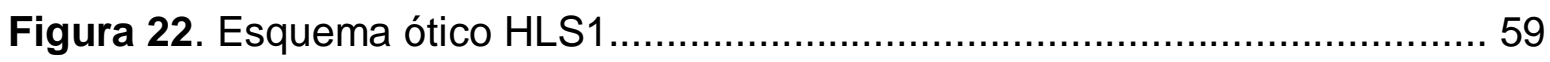

Figura 23. Lâmpada 2 Osram 41850SP (Osram, 2008)................................... 59

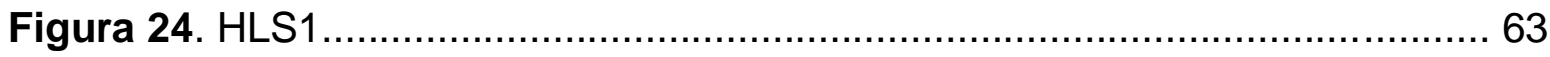

Figura 25. Irradiância x distância HLS1 _.......................................................... 64

Figura 26. Irradiância x distância axial HLS1 a 5 e a 15cm da lâmpada................ 65

Figura 27. Temperatura do corpo $x$ tempo do HLS1 ..........................................6 66

Figura 28. Desenho técnico do corpo do HLS2 ................................................ 70

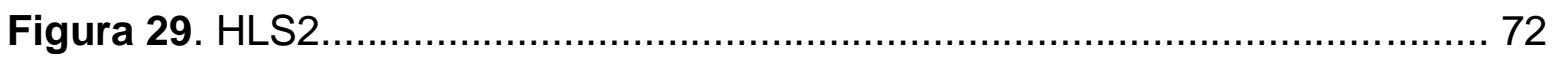

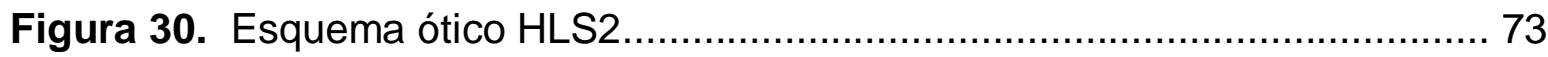

Figura 31. Irradiância x distância HLS2 ……………...................................... 74

Figura 32. Irradiância x distância axial HLS2 a 5 e a 15cm da lâmpada.............. 74

Figura 33. Temperatura do corpo $x$ tempo do HLS2 ........................................... 75

Figura 34. Temperatura do filtro térmico HLS2 ……...................................... 76

Figura 35. Desenho técnico do corpo do HLS3................................................. 79

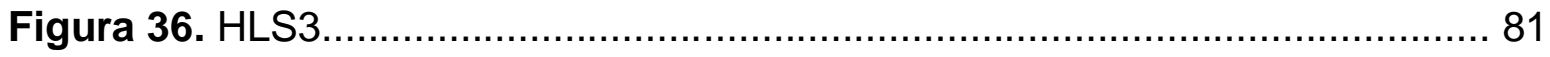

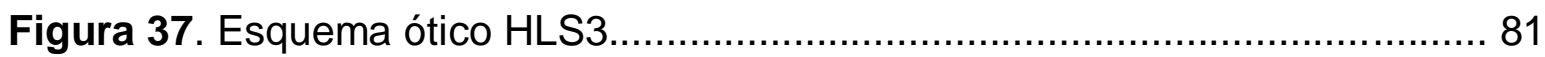

Figura 38. Irradiância x distância HLS3 ......................................................... 83

Figura 39. Irradiância x distância axial HLS3 a 5 e a $15 \mathrm{~cm}$ da lâmpada............... 83

Figura 40. Temperatura do corpo $\mathrm{x}$ tempo do HLS3 ......................................... 84

Figura 41. TRM.

Figura 42. Fotocitotoxicidade do Photogem ${ }^{\circledR}$ em cultura de células de HT29.......87 


\section{Lista de Tabelas}

Tabela 1 - Características de absorção óptica de alguns fotossensibilizadores para

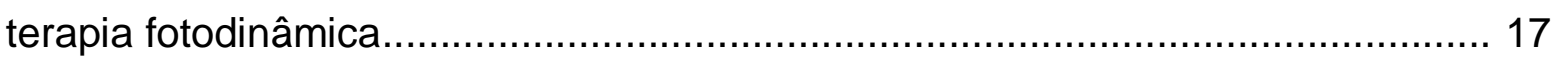

Tabela 2 - Quantidades radiométricas usuais (Sliney, 2007).............................. 20

Tabela 3 - Light source for ALA-PDT (Morton et al., 2002) ................................ 28

Tabela 4- Dimensão do mercado de fotobiologia (Lee et al., 2007)...................... 30

Tabela 5 - Crescimento do mercado de fotobiologia (Lee et al., 2007)................. 31

Tabela 6 - Resultado do critério de seleção das lâmpadas................................. 47 


\section{Sumário}

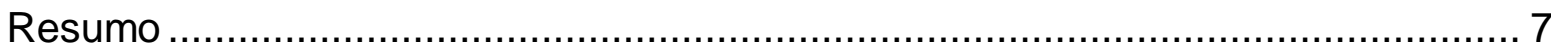

Abstract

Erro! Indicador não definido.

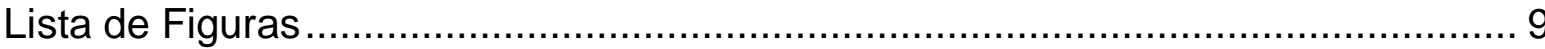

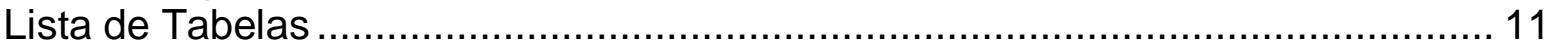

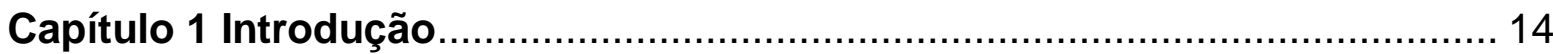

1.1 Luz na biologia, biotecnologia e medicina ..................................................... 14

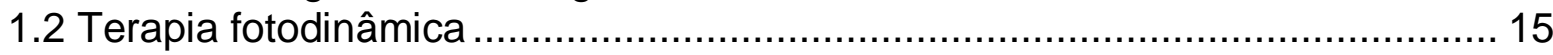

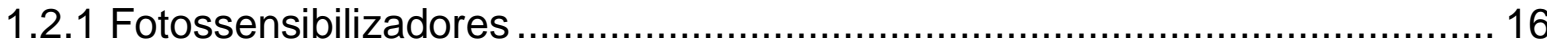

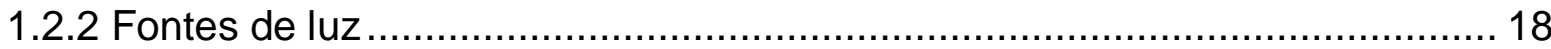

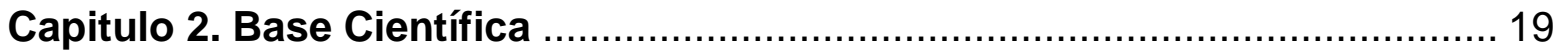

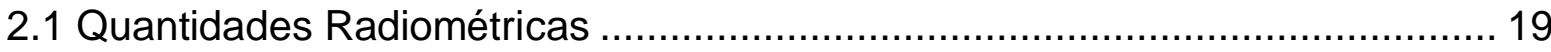

2.2 Características físicas de fontes luminosas................................................ 22

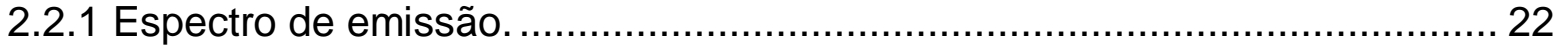

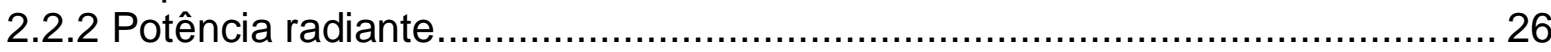

2.2.3 Distribuição espacial da potência radiante .............................................. 27

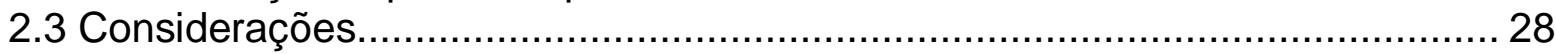

Capítulo 3 Processo de Desenvolvimento de Produto ................................... 30

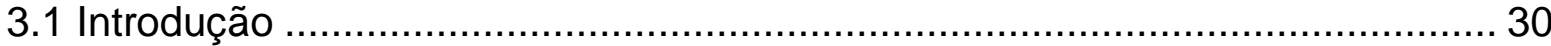

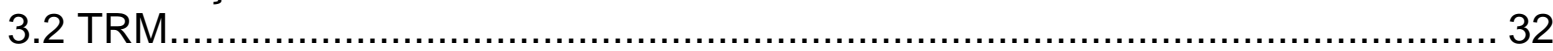

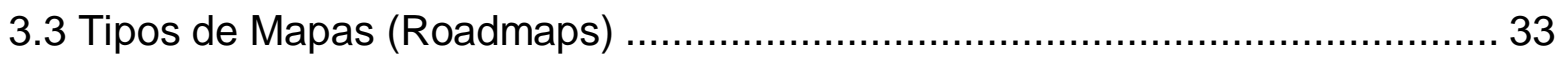

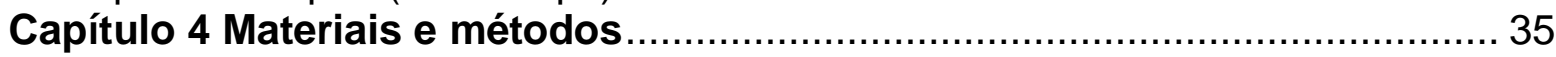

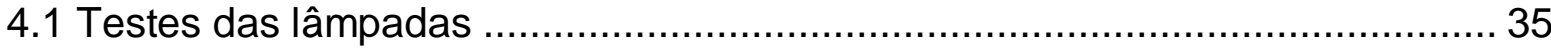

4.1.1 Critério de seleção das lâmpadas halógenas ............................................ 35

4.1.2 Descrição dos equipamentos utilizados ................................................ 37

4.1.2.1 Medidor de Intensidade luminosa Spectra Physics 407A .......................... 37

4.1.2.2 Espectrômetro CVI-240A ................................................................. 38

4.1.2.3 Espectrofotômetro Beckman Coulter DU640 ............................................ 39

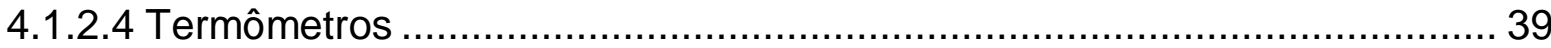

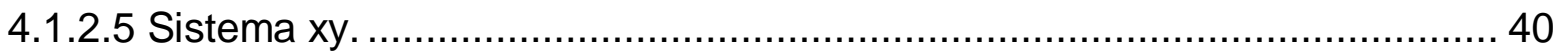

4.1.3 Medidas dos espectros de emissão. ...................................................... 40

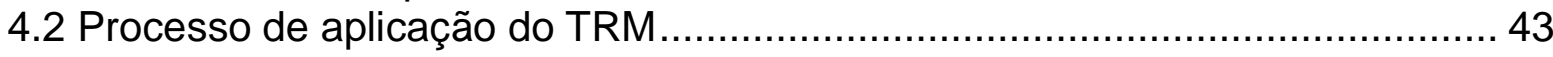

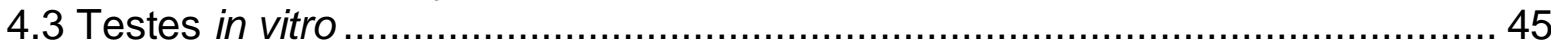

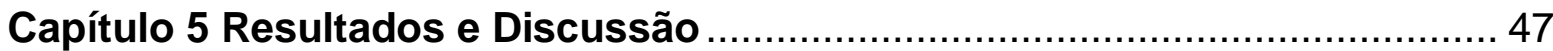

5.1 Resultados dos testes das lâmpadas. ................................................... 47

5.1.1 Resultados do critério de seleção das lâmpadas halógenas ........................ 47

5.1.2 Medidas do espectro com espectrômetro SM240A. ................................... 48

5.1.3 Resultados das medidas de irradiância longitudinal .................................... 49

5.2 Discussão dos resultados e considerações................................................. 51

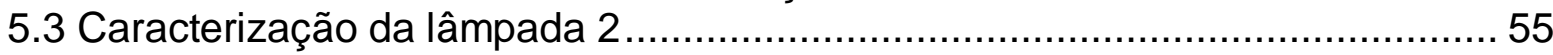

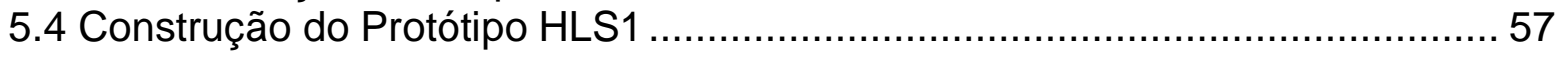

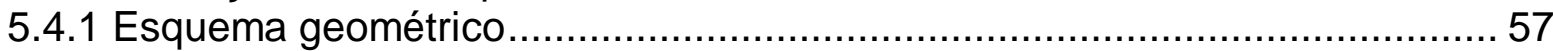

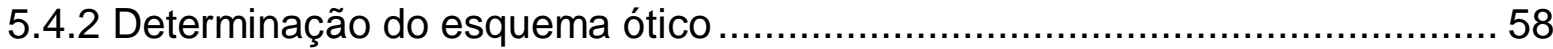

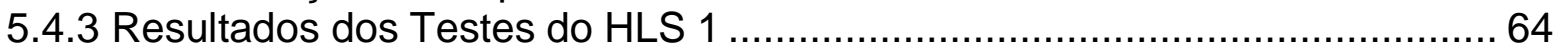




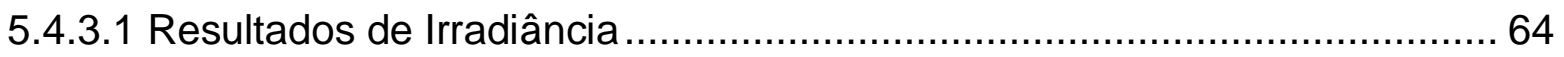

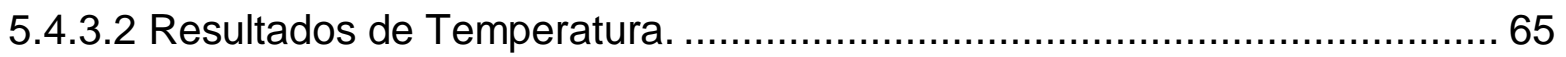

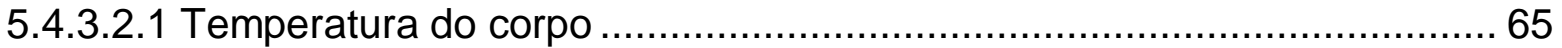

5.4.3.2.2 Temperatura do sistema de filtro térmico .............................................6 66

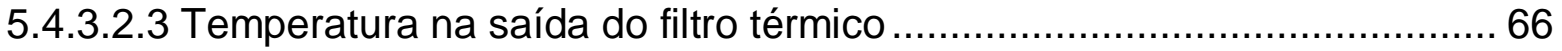

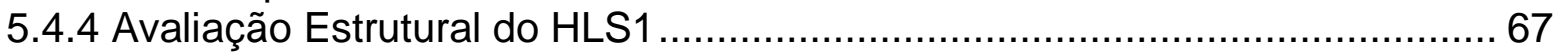

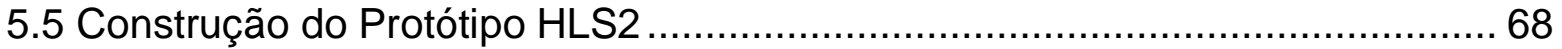

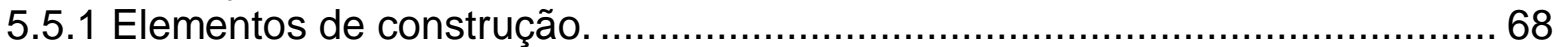

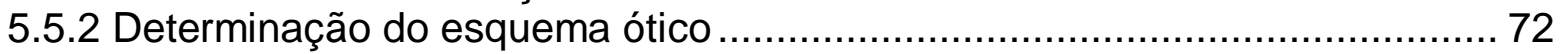

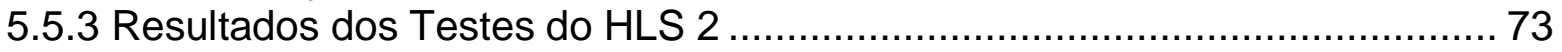

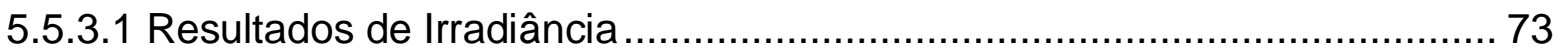

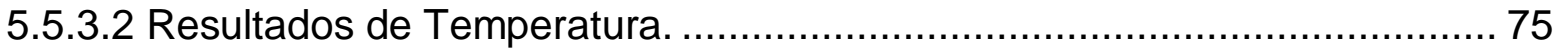

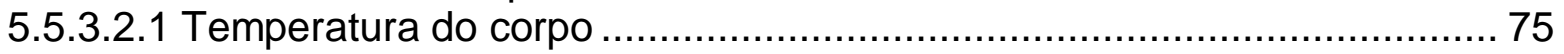

5.5.3.2.2 Temperatura do sistema de filtro térmico ............................................ 76

5.5.3.2.3 Temperatura na saída do filtro térmico .............................................. 77

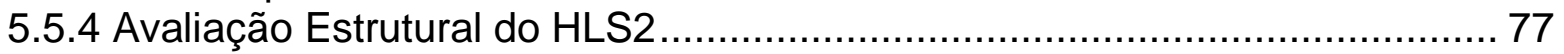

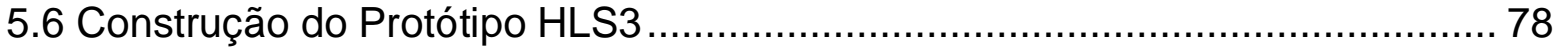

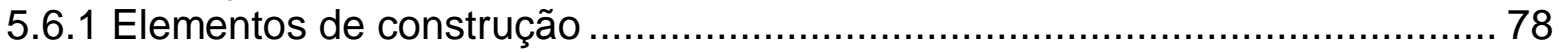

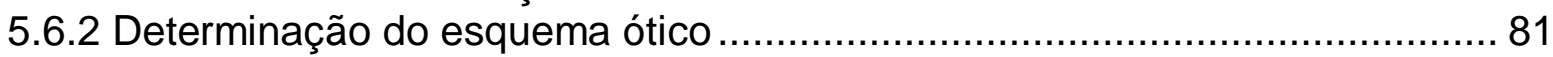

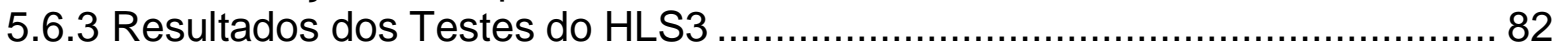

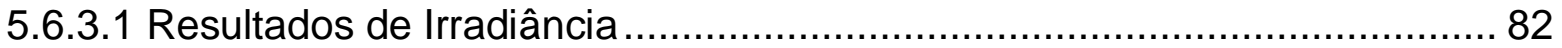

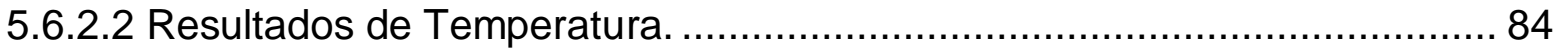

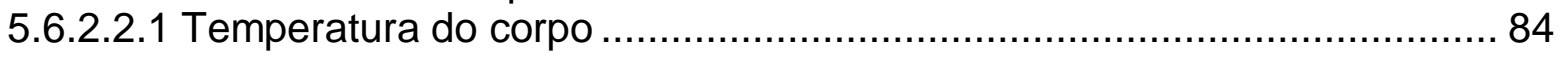

5.6.2.2.2 Temperatura do sistema de filtro térmico ............................................. 85

5.6.2.2.3 Temperatura na saída do filtro térmico ............................................. 85

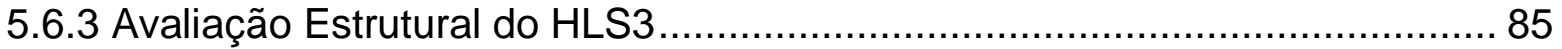

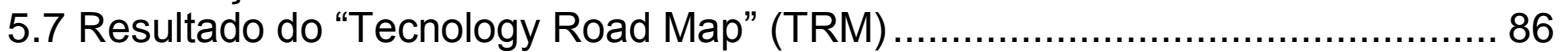

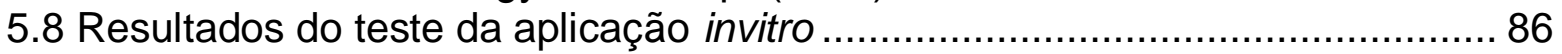

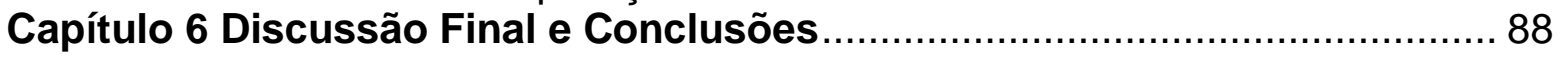

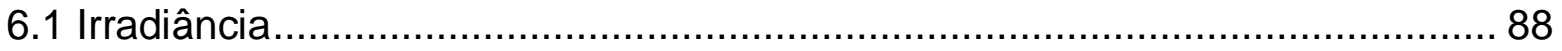

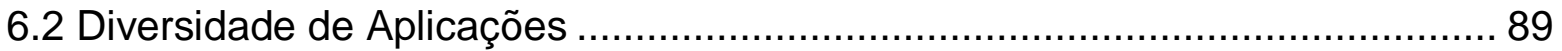

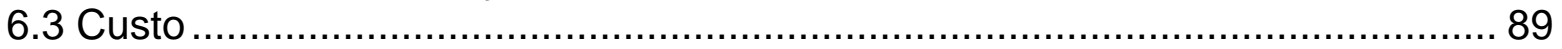

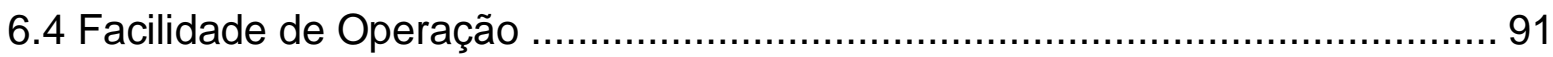

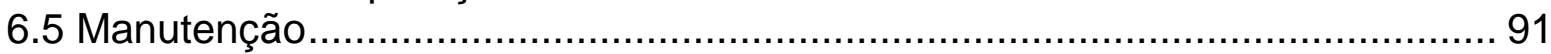

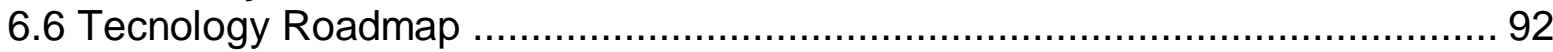

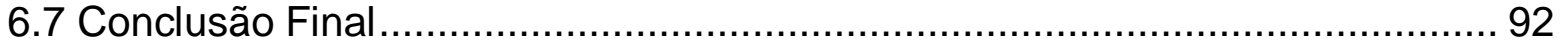

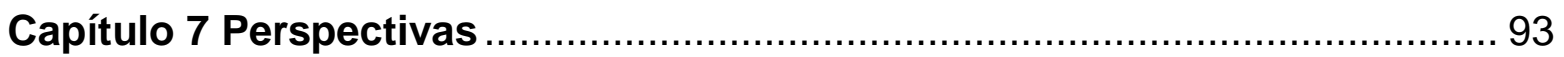

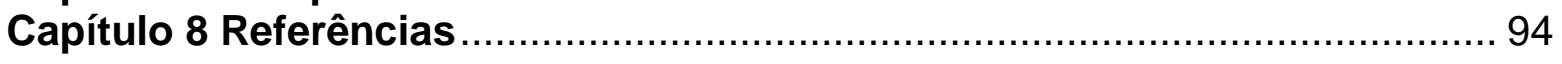




\section{Capítulo 1 Introdução}

\subsection{Luz na biologia, biotecnologia e medicina}

A fotobiologia e a fotomedicina são áreas em que, nas ultimas décadas, muitos esforços têm sido concentrados em busca do desenvolvimento de novas tecnologias, especialmente no campo da nanotecnologia, como: aplicações conjuntas de luz e de nanoestruturas biológicas em novas gerações de computadores dotados de chaves ópticas ultra-rápidas (Loppacher, et al. 2003; Liu, et al. 2002), micromódulos de memórias tridimensionais de alta capacidade (Birge, 1992), no desenvolvimento da técnica de lasers (Yang 1997), limitadores ópticos (Calvete, et al. 2004; Dini, et al. 2005), holografia (Kothapalli, et al. 2004; Wu, et al. 2004), como também na medicina moderna, principalmente na área de fotoquimioterapia (Dougherty, et al. 1978; Henderson, et al. 1992; Dougherty, 1993; Ochsner, 1997; Brown, 2004).

Nestas aplicações em fotoquimeoterapia a absorção da energia luminosa se realiza pelos compostos, chamados fotossensibilizadores, que já podem estar presentes nas estruturas biológicas (intrínsecos) ou serem introduzidos nestas estruturas (extrínsecos). A energia absorvida pelos fotossensibilizadores é utilizada posteriormente para realização de reações secundárias que são necessárias ao

processo fotodinâmico. Geralmente a luz usada nestas aplicações é pertencente à região visível do espectro luminoso. 


\subsection{Terapia fotodinâmica}

Durante a década de 70 , foram iniciadas aplicações clinicas de um novo método de tratamento de doenças graves, inclusive o câncer, denominado Fotoquimioterapia (do inglês, Photodynamic Terapy - PDT).

O princípio desse método é introduzir no organismo do paciente um composto fotossensibilizador, que não está ativo no seu estado fundamental, e em seguida iluminar a região do corpo a ser tratada com luz visível, induzindo a formação do estado excitado eletrônico singleto $S_{1}$ do composto fotossensibilizador, este por sua vez induz a ocorrência de vários processos secundários que produzem como resultado a morte do tecido iluminado.

A forma de PDT mais desenvolvida e já aplicada na clínica é aquela baseada no efeito fotodinâmico realizado em dois mecanismos (Dougherty, et al. 1978; Henderson, et al. 1992; Dougherty, 1993; Ochsner, 1997; Brown, 2004).

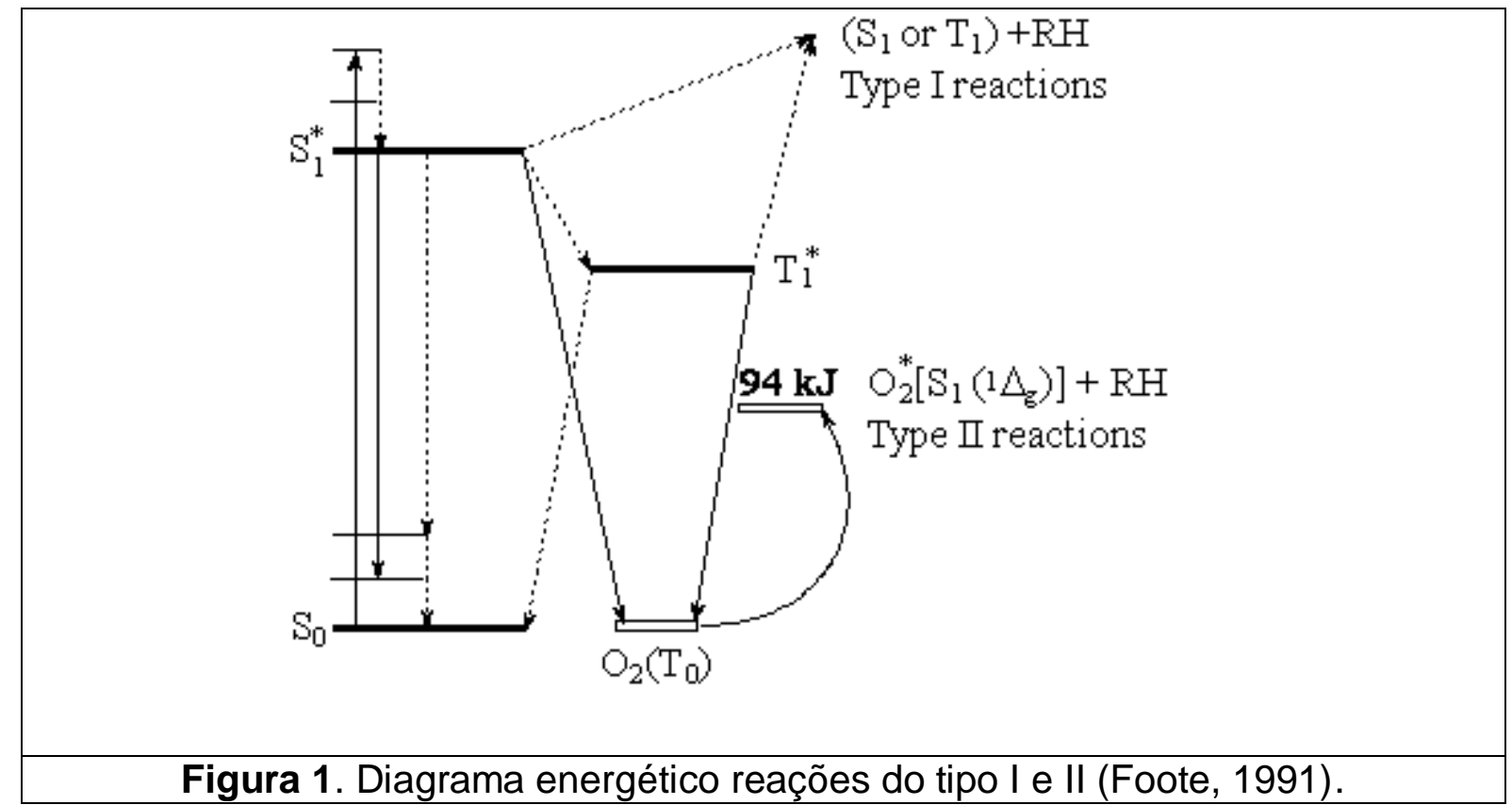

Figura 1. Diagrama energético reações do tipo I e II (Foote, 1991). 
Mecanismo Tipo I: O composto fotoativo no estado $S_{1}$ ou $T_{1}$ pode, por reações de oxidação e redução com diferentes biomoléculas, ser foto-reduzido a ânion radical, que por transferência de um elétron à molécula de oxigênio, gera espécies reativas

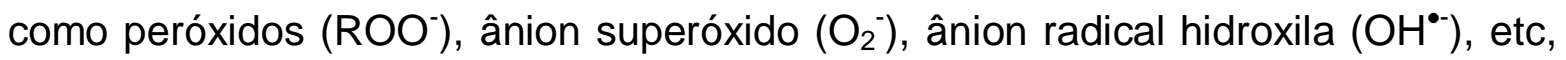
provocando a destruição da membrana ou de macromoléculas. Finalmente o fotossensibilizador volta para seu estado fundamental.

Mecanismo Tipo II: A molécula no estado $T_{1}$ transfere sua energia para molécula de oxigênio cujo estado fundamental é tripleto $\left({ }^{3} \mathrm{O}_{2}\right)$, formando finalmente seu estado excitado singleto $\left({ }^{1} \mathrm{O}_{2}\right)$. O oxigênio singleto será a chave intermediária no processo fotodinâmico, sendo o principal responsável pela inativação da célula. 0 ${ }^{1} \mathrm{O}_{2}$ pode induzir várias reações em cadeia com componentes moleculares da célula, tais como: DNA, proteínas, fosfolipídios da membrana celular, mitocôndrias, lisossomos, etc., tendo como o resultado a morte da célula e, de um modo geral, a destruição do tumor.

\subsubsection{Fotossensibilizadores}

Os candidatos a compostos fotossensibilizadores devem preencher diversos critérios em relação a propriedades físicoquímicas, fotofísicas, farmacológicas e fototerapêuticas (Lang, 2004). Entre estas uma das principais é a necessidade de possuir uma alta absorção na região espectral 600 - 800 nm. 
Derivados de Hematoporfirina $(\mathrm{HpD})$ e sua fração ativa, Photofrin $^{\circledR}$, Photogem $^{\circledR}$ e $\operatorname{Photosan}^{\circledR}$, constituem a primeira geração de agentes fototerapêuticos utilizados em aplicações clínicas no tratamento de tumores.

Apesar da sua eficácia na eliminação de tumores, estes fármacos apresentam algumas desvantagens: possuem uma fraca absorção de luz na região $\lambda>600 \mathrm{~nm}$, não são muito seletivos e podem induzir a fotossensibilidade da pele por várias semanas após a sua administração (Lang, et al 1995; Schuitmaker, et al 1996).

Diversos corantes estão sob investigação para aplicação em PDT. Os derivados de clorinas, ftalocianinas e benzoporfirinas, chamados de segunda geração de fotossensibilizadores, têm sido desenvolvidos e alguns deles já estão sendo utilizados em PDT (Zheng, et al. 2000; Hammer-Wilson, et al. 1999; Cunderlikova et al. 1999).

\begin{tabular}{|c|c|c|}
\hline Nome & $\begin{array}{l}\text { Posição do máximo de } \\
\text { absorção } \lambda_{\max }(\mathrm{nm})\end{array}$ & $\begin{array}{l}\text { Coeficiente de absorção } \\
\text { molar } \varepsilon\left(\mathrm{M}^{-1} \mathrm{~cm}^{-1}\right)\end{array}$ \\
\hline Photofrin® & 630 & 3200 \\
\hline Benzoporphyrinderivateve & 690 & 43000 \\
\hline Monoaspartyl-chlorin $\mathbf{e}_{6}$ & 675 & 47000 \\
\hline Sn(IV)-etiopurpurin & 660 & 28000 \\
\hline $\mathrm{Zn}(\mathrm{II})$-phthalocyanine & 675 & 243000 \\
\hline Biscyanine I & 630 & 180000 \\
\hline
\end{tabular}




\subsubsection{Fontes de luz}

As fontes de luz geralmente utilizadas nas aplicações anotadas acima são lasers e, recentemente, os leds de alta potência. Essas fontes possuem várias características vantajosas, tais como: monocromatismo, feixe de luz não divergente e alta intensidade. Por outro lado elas também possuem algumas desvantagens como: alto preço e alto custo de manutenção. Além disso, as características, que são vantajosas e adequadas para algumas finalidades podem ser consideradas não adequadas para outras. Por exemplo, os fotossensibilizadores utilizados em fotoquimioterapia possuem as bandas de absorção bastante amplas em fase líquida (espessura na meia altura $\approx 1000-1500 \mathrm{~cm}^{-1}$ ). Com o uso de lasers e leds, que possuem bandas da emissão bem estreitas (espessura na meia altura $<70 \mathrm{~cm}^{-}$

${ }^{1}$ ) grande parte do espectro de absorção desses compostos é perdida, pois é muito difícil encontrar fontes de laser ou leds que possam abranger todo o espectro da absorção do FS ou no mínimo coincidir com a região da sua maior absorção. Com relação à irradiância (potência luminosa emitida por área irradiada dada em W/cm²) verificamos que os lasers e os leds possuem alta irradiância em regiões de pequena área, já quando a aplicação exige que a área irradiada seja maior o uso de difusores causa uma perda significativa nessa irradiância.

Neste aspecto as lâmpadas de filamento, especialmente na versão halógena, podem competir com sucesso com os lasers e leds. A adequação dessas fontes para aplicação em fotoquimioterapia já foi demonstrada para tratamento de alguns tipos de câncer (Levy, et al 1995; Ito;Tardivo, 2004). 
Em vários países essas fontes baseadas nas lâmpadas de filamento foram construídas e produzidas industrialmente para aplicações na fotobiologia e fotomedicina, como exemplo, podemos citar a fonte denominada Lumacare $\AA$, que recentemente conseguiu aprovação das agencias reguladoras de saúde americana e européia (Lumacare®, 2008).

Estas fontes alem de possuir um custo menor que as demais, baseadas principalmente em lasers e leds, são caracterizadas por possuir: alta intensidade de irradiação, diversidade de aplicações e simples manutenção. Entretanto, no Brasil atualmente não existem as fontes industriais deste tipo dedicadas para aplicações médicas e biológicas.

O objetivo deste trabalho foi construir uma fonte coma as características mencionadas acima para suprir uma necessidade do mercado brasileiro.

Para atingir este objetivo decidimos utilizar nesse projeto principalmente componentes produzidos industrialmente.

\section{Capitulo 2. Base Científica}

\subsection{Quantidades Radiométricas}

De acordo com (Sliney, 2007) que baseou seu trabalho na CIE (International Commission on Illumination) as quantidades radiométricas que são usualmente utilizadas para caracterizar a transmissão e absorção de luz por um meio ótico estão expressas na tabela abaixo: 


\begin{tabular}{|c|c|c|c|c|}
\hline \multicolumn{5}{|c|}{ Tabela 2 - Quantidades radiométricas usuais (Sliney, 2007). } \\
\hline Term & Symbol & Defining equation & Defining equation & Unit and abbreviation \\
\hline Radiant energy & $Q$ & $\begin{array}{l}\text { Energy emitted, transferred, or received } \\
\text { in the form of radiation }\end{array}$ & & Joule (J) \\
\hline Radiant power & $\Phi$ & Radiant energy per unit time & $\Phi=\frac{\mathrm{d} Q \mathrm{e}}{\mathrm{d} t}$ & Watt $(\mathrm{W})$ defined as $\mathbf{J} \cdot \mathrm{s}^{-1}$ \\
\hline $\begin{array}{l}\text { Radiant exposure } \\
\text { (dose in photobiology) }\end{array}$ & $H$ & $\begin{array}{l}\text { Radiant energy per unit area incident } \\
\text { upon a given surface }\end{array}$ & $H=\frac{\mathrm{d} Q_{e}}{\mathrm{~d} A}$ & Joule per square meter $\left(\mathrm{J} \cdot \mathrm{m}^{-2}\right)$ \\
\hline $\begin{array}{l}\text { Irradiance or radiant flux } \\
\text { density } \\
\text { (dose rate in photobiology) }\end{array}$ & $E$ & $\begin{array}{l}\text { Radiant power per unit area incident } \\
\text { upon a given surface }\end{array}$ & $E=\frac{\mathrm{d} \Phi_{e}}{\mathrm{~d} A}$ & Watt per square meter $\left(\mathrm{W} \mathrm{m}^{-2}\right)$ \\
\hline Fluence & $I_{\mathrm{P}}$ & $\begin{array}{l}\text { Radiant energy emitted by a source } \\
\text { per unit solid angle }\end{array}$ & $I=\frac{\mathrm{d} \Phi_{e}}{\mathrm{~d} \Omega}$ & Joule per Steradian $\left(\mathrm{J} \cdot \mathrm{sr}^{-1}\right)$ \\
\hline Radiant intensity & $I$ & $\begin{array}{l}\text { Radiant power emitted by a source } \\
\text { per unit solid angle }\end{array}$ & $I=\frac{\mathrm{d} \Phi_{e}}{\mathrm{~d} \Omega}$ & Watt per Steradian $\left(\mathrm{W} \cdot \mathrm{sr}^{-1}\right)$ \\
\hline Radiant fluence rate & $E_{\mathrm{e}, \mathrm{o}}$ & $\begin{array}{l}\text { Radiant energy emitted by } \\
\text { a source per unit } \\
\text { solid angle per source area }\end{array}$ & $E_{\mathrm{e}, \mathrm{o}}=\int_{4 \pi s r} L_{\mathrm{e}} \mathrm{d} \Omega$ & $\begin{array}{l}\text { Joules per Steradian per } \\
\text { square centimeter }\left(\mathrm{J} \cdot \mathrm{sr}^{-1} \cdot \mathrm{m}^{-2}\right)\end{array}$ \\
\hline Radiance & $L$ & $\begin{array}{l}\text { Radiant power emitted by } \\
\text { a source per unit } \\
\text { solid angle per source area }\end{array}$ & $L=\frac{\mathrm{d} \Phi e}{\mathrm{~d} \Omega \mathrm{d} A \cdot \cos \theta}$ & $\begin{array}{l}\text { Watts per Steradian per square } \\
\text { centimeter }\left(\mathrm{W} \cdot \mathrm{sr}^{-1} \cdot \mathrm{m}^{-2}\right)\end{array}$ \\
\hline Optical density (OD) & $D_{\lambda}$ & $\begin{array}{l}\text { A logarithmic expression } \\
\text { for the attenuation } \\
\text { produced by a filter on }\end{array}$ & $D_{\lambda}=-\log _{10}\left(\frac{\Phi_{Q}}{\Phi_{L}}\right)$ & $\begin{array}{l}\text { Dimensionless } \\
\Phi_{\mathrm{O}} \text { is the incident power; } \\
\Phi_{\mathrm{L}} \text { is the transmitted power }\end{array}$ \\
\hline \multicolumn{5}{|c|}{ 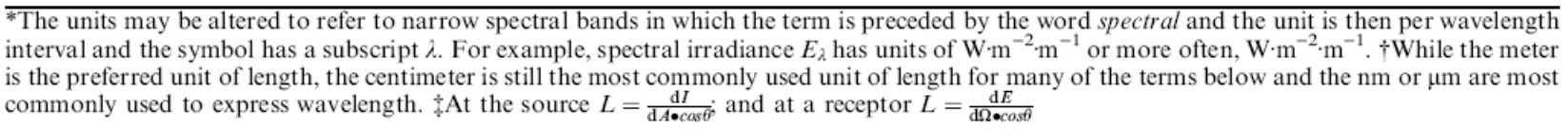 } \\
\hline
\end{tabular}

Dentre elas as usualmente utilizadas na fotobiologia são: a "irradiância" $(E)$, que é definida pela potência radiante incidente por unidade de área numa determinada superfície, tendo como unidade Watt por metro quadrado $\left(\mathrm{W} / \mathrm{m}^{2}\right)$ e a "exposição radiante" $(H)$, usualmente tratada como "dose" e definida pela energia radiante incidente por unidade de área numa determinada superfície, tendo como unidade Joule por metro quadrado $\left(\mathrm{J} / \mathrm{m}^{2}\right)$.

Entretanto, as unidades $\mathrm{W} / \mathrm{m}^{2}$ e $\mathrm{J} / \mathrm{m}^{2}$ são adequadas para comparação das irradiâncias e doses em caso de uso da luz monocromática de fixo comprimento de onda, quando que para calcular estas características em caso da radiação distribuída em uma ampla região espectral é mais adequado usar as unidades 
$\mathrm{N} / \mathrm{m}^{2}$ para irradiância e $(\mathrm{N} \mathrm{t}) / \mathrm{m}^{2}$, onde $\mathrm{N}$ é o número total dos fótons emitidos durante um segundo para uma unidade da superfície em toda região espectral da emissão e t é o tempo da irradiação.

Realmente, a velocidade de qualquer fotoreação depende somente do número dos fótons absorvidos pelo sistema e não depende da sua energia (Turro, 1991). Esta consideração está baseada no fato que para realizar a fototransformação de uma molécula é necessário e suficiente somente um fóton que possui a energia:

$$
\mathrm{h} v=\mathrm{E}_{\min }^{*}-\mathrm{E}_{0}
$$

em que $h$ é constante de Planck, $v$ é freqüência característica do fóton, $E_{\text {min }}^{*}$ é energia do estado excitado mais baixo e $\mathrm{E}_{0}$ é a energia do estado fundamental da molécula. A energia maior dos fótons que podem transmitir a molécula para os estados excitados mais altos será parcialmente perdida, devido os processos não radiativos da interconveção e de cruzamento intersistemas.

A energia emitida por uma fonte durante um segundo por unidade de área num comprimento de onda definido é igual

$$
E=h v N / t\left(\mathrm{~W} / \mathrm{m}^{2}\right)
$$

Assim podemos determinar o número dos fótons emitidos por um segundo neste comprimento de onda $\lambda$ como 


$$
\mathrm{N} / \mathrm{t}=E / \mathrm{h} v=E \lambda / \mathrm{hc}
$$

Em que c é a velocidade da luz.

Neste trabalho para caracterizar as lâmpadas e a fonte produzida utilizamos a Irradiância na forma (1) e a exposição radiante (dose) como (EN/hc)t, onde t é o tempo da irradiação, na caracterização da irradiância em função da distância utilizaremos a irradiância em $\mathrm{mW} / \mathrm{cm}^{2}$, de forma a adotar a nomenclatura usualmente utilizada.

\subsection{Características físicas de fontes luminosas}

As características físicas básicas de qualquer fonte luminosa são:

i. o espectro de emissão;

ii. a potência radiante;

iii. a distribuição espacial da potência radiante.

\subsubsection{Espectro de emissão.}

Em geral a luz aplicada na: fotobiologia, biotecnologia e fotomedicina, pertence à região visível e do infravermelho próximo do espectro (400 - 800 nm).

Um interesse especial possui a região espectral entre 600 e $800 \mathrm{~nm}$ chamada "janela terapêutica" (Dougherty, et al. 1978), onde os tecidos biológicos 
são relativamente transparentes, o que permite a penetração mais profunda da energia luminosa dentro de tecidos.

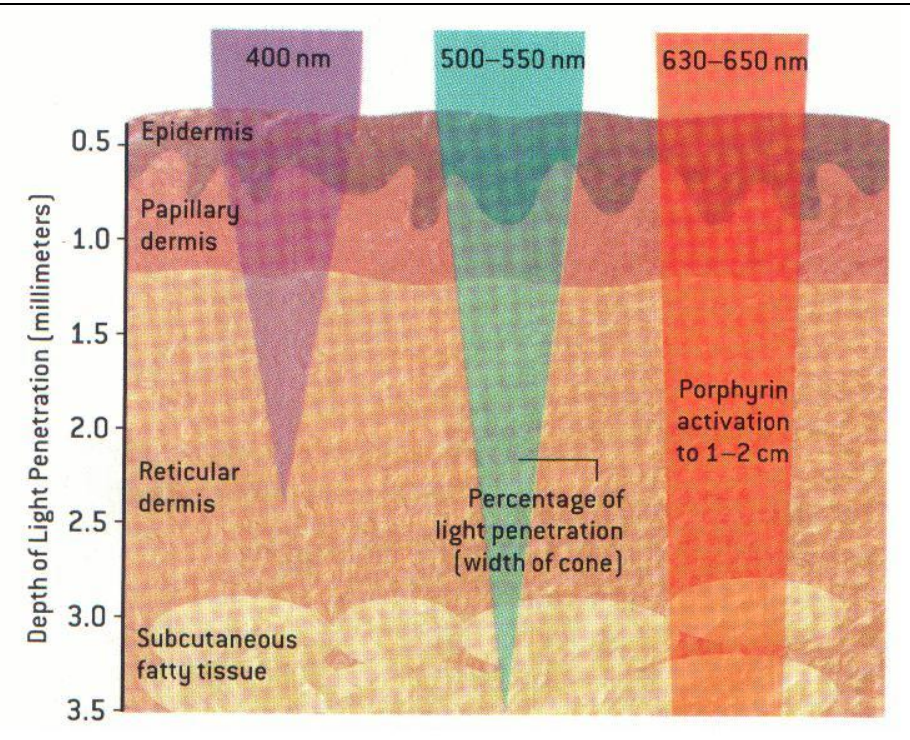

Figura 2. Profundidade da penetração da energia luminosa dentro de tecidos biológicos em função do comprimento de onda (Scientific American, 2003).

\subsubsection{Espectros da emissão das lâmpadas}

Existem diferentes tipos de lâmpadas para diversos tipos de aplicação. Neste trabalho utilizaremos lâmpadas de filamento em especial às lâmpadas halógenas. A seguir faremos uma comparação das lâmpadas incandescentes (comuns) com as halógenas.

As lâmpadas incandescentes são constituídas de: um bulbo de vidro, um filamento (tungstênio), condutor e um suporte central de vidro um meio de encaixe, como podemos observar no esquema da figura abaixo: 


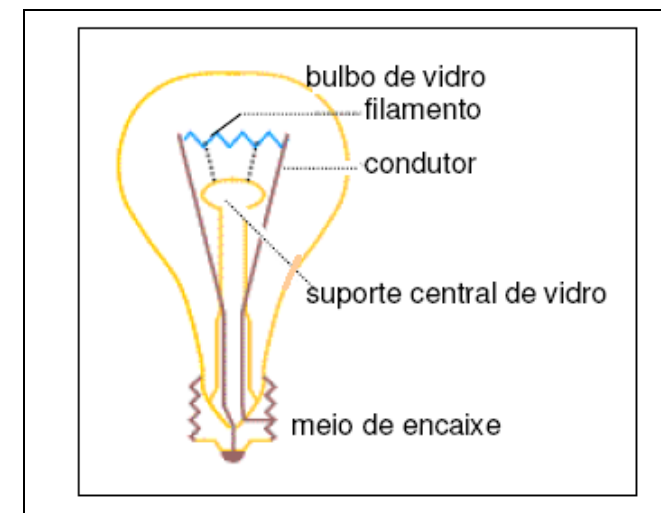

a

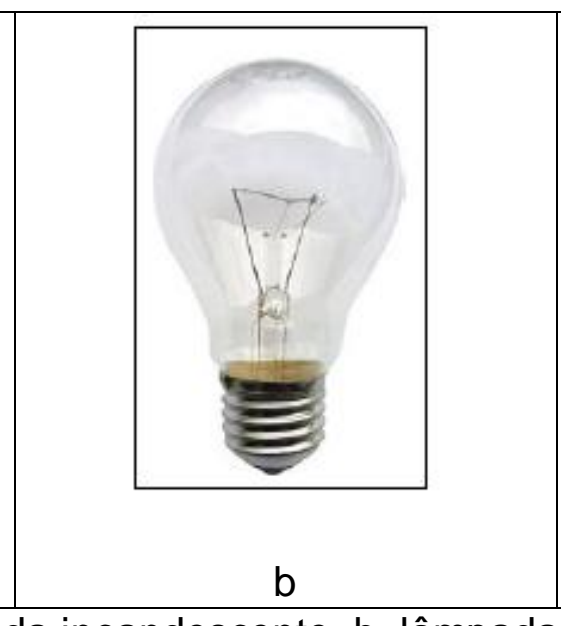

b

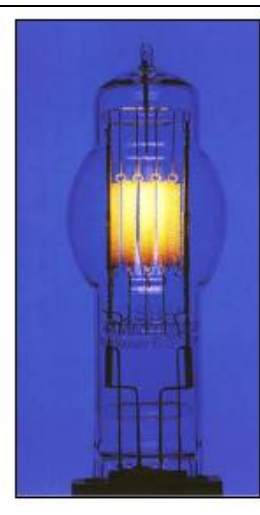

C

Figura 3. a. Esquema da lâmpada incandescente. b. lâmpada incandescente c. lâmpada halógena. (PucRio, 2008).

O princípio de funcionamento é simples a corrente que passa pelo filamento de tungstênio provoca seu aquecimento a cerca de $2800 \mathrm{~K}$ onde ocorre emissão em uma ampla faixa espectral de infravermelho (calor) até aproximadamente $400 \mathrm{~nm}$ (visível). Se o filamento estivesse exposto ao ar, devido à ação do oxigênio este filamento seria oxidado e se romperia rapidamente, entretanto atualmente o bulbo é preenchido com um gás inerte (argônio) para aumentar o tempo de vida desta lâmpada ( 1000h).

As lâmpadas halógenas possuem o mesmo princípio, no entanto, o gás que preenche o bulbo (criptônio ou xenônio) possui traços de um elemento da família dos halogênios (bromo ou iodo). O halogênio tem a propriedade de se combinar com os átomos de tungstênio evaporados e depositá-los novamente no filamento. Dessa forma podemos aumentar a temperatura deste deslocando o espectro para a região de comprimentos de onda menores, aumentando a eficiência luminosa na 
região visível. A temperatura de filamento em lâmpadas halógenas pode atingir aproximadamente $3600 \mathrm{~K}$ e seu tempo de vida útil, cerca de $3000 \mathrm{~h}$.

A teoria mostra que o espectro da emissão de radiação eletromagnética de qualquer objeto (estrelas, filamentos metálicos etc.) pode ser modelado através do espectro da emissão do corpo negro da respectiva temperatura.

.A seguir apresentamos a equação de Planck, que descreve a magnitude da energia radiante do corpo negro em função do comprimento de onda.

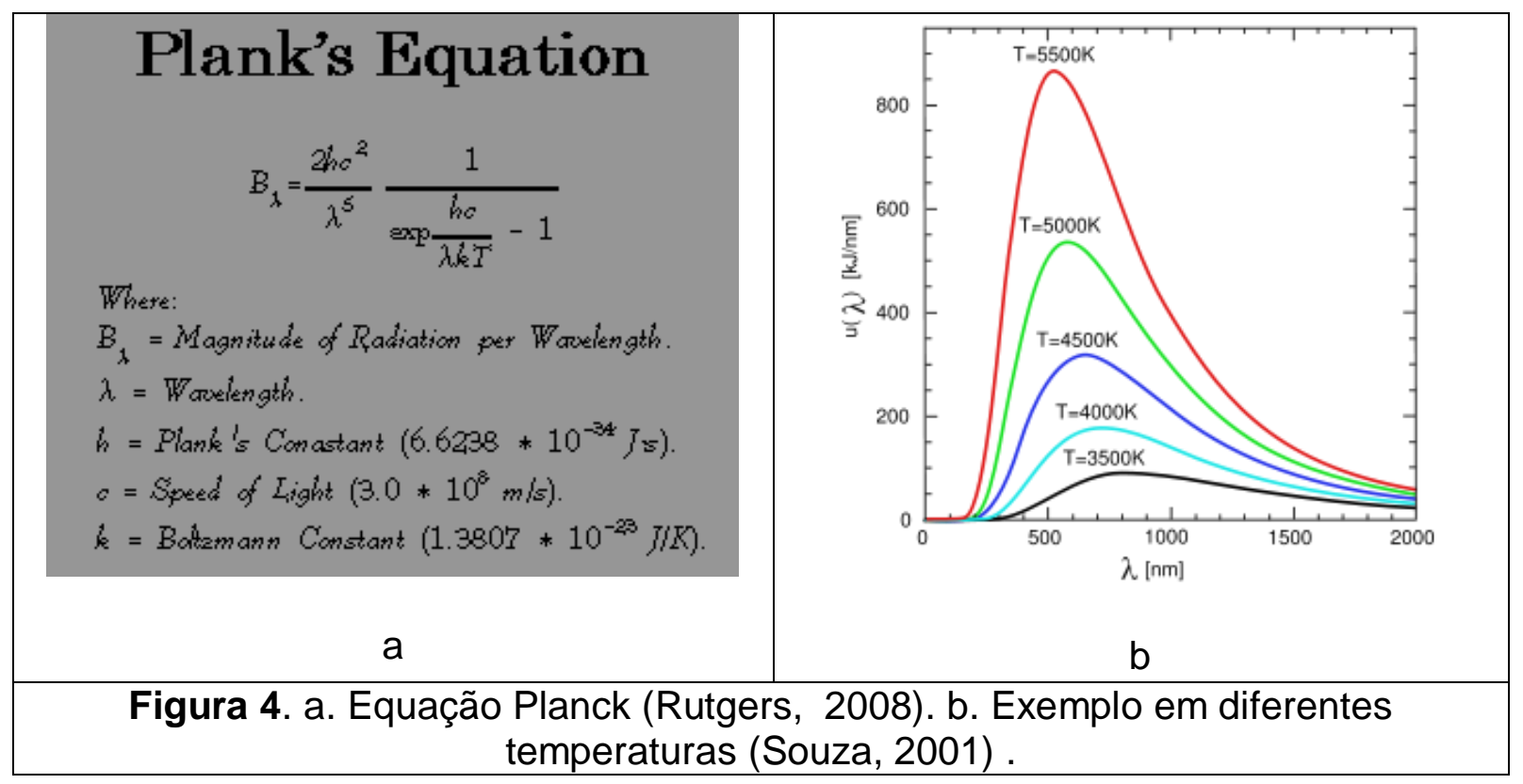

Como podemos observar no gráfico acima, com o aumento da temperatura, ocorre um deslocamento do espectro para menores comprimentos de onda. Assim podemos comparar o espectro de emissão das lâmpadas de filamento com o 
espectro de corpo negro, sendo que a temperatura absoluta do corpo negro é definida como a temperatura de cor das lâmpadas (Souza, 2001).

Para efeito de comparação as lâmpadas halógenas possuem temperatura de cor em torno de $3600 \mathrm{~K}$ enquanto o sol 5900K. Desse modo as lâmpadas halógenas devem possuir grande parte da sua emissão dentro da região visível do espectro.

\subsubsection{Potência radiante}

A potência radiante emitida de uma lâmpada depende, entre outros fatores da sua potência elétrica. Para uma lâmpada halógena de potência elétrica 100W temos que a potência radiante é aproximadamente $10 \%$, ou seja, cerca de $10 \mathrm{~W}$ (Osram, 2008). Para efeito de comparação, o laser de mesma potência de entrada emite uma potência radiante $\approx 250 \mathrm{~mW}$, entretanto, no caso da lâmpada halógena está potência esta distribuída em todo espectro, enquanto no laser ela esta concentrada numa estreita faixa espectral em torno de um comprimento de onda principal.

Como foi mostrado por (Morton et al., 2002), valores de irradiância acima de $150 \mathrm{~mW} / \mathrm{cm}^{2}$ podem causar queimaduras dos tecidos biológicos. O valor típico da irradiância aplicada em fotoquimioterapia é de aproximadamente $50 \mathrm{~mW} / \mathrm{cm}^{2}$ (Morton et al., 2002; Grossweiner, 1997), portanto lâmpadas halógenas que possuem irradiância em torno $200 \mathrm{~mW} / \mathrm{cm}^{2}$ (Morton et al., 2002) são fontes promissoras para estas aplicações. 


\subsubsection{Distribuição espacial da potência radiante}

De acordo com (Morton et al., 2002), sabemos que a potência radiante do laser utilizado na fotobiologia está concentrada em uma estreita região espectral e dentro de uma estreita área espacial, fato que torna o laser uma fonte com alta especificidade para determinados tipos de aplicação.

No entanto, em diversas aplicações da fotoquimioterapia se faz necessário o uso em áreas maiores, desse modo o laser com o uso de difusores tem sua potência radiante reduzida drasticamente. Por exemplo, na iluminação de uma área circular de $10 \mathrm{~cm}^{2}$ (raio $\approx 1,8 \mathrm{~cm}$ ) a potência radiante do laser anotado acima por $\mathrm{cm}^{2}$ (irradiância), diminui para $20 \mathrm{~mW}$.

Em contrapartida as lâmpadas halógenas podem apresentar uma maior potência radiante numa maior área se mostrando mais eficientes neste tipo de aplicação. A tabela abaixo mostra os valores típicos da irradiância de cinco diferentes tipos de fontes. A grandeza foi denominada erroneamente de "fluence rate", pois de acordo com CIE esta grandeza é medida em W/cm² sr, no entanto, como o autor especificou a unidade fica claro que se trata da grandeza denominada Irradiância que é medida em W/cm². 


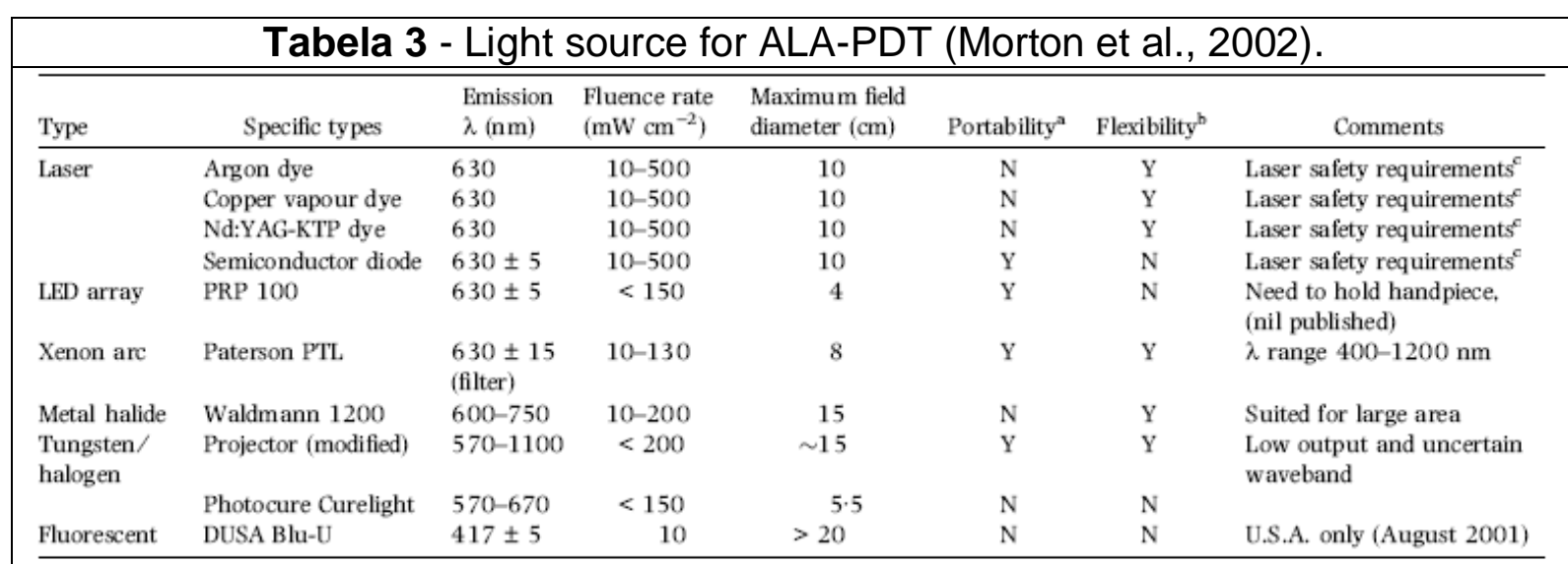

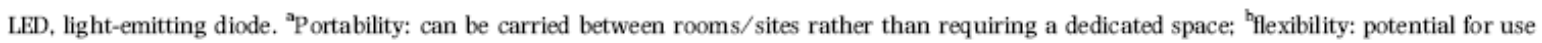
with alternative photosensitizers, e.g. availability of other wavelengths; " Geam delivery via 400- $\mu \mathrm{m}$ fibre suitable for systemic PDT.

Podemos notar na tabela acima, que as lâmpadas halógenas possuem a irradiância comparável com outras fontes, fato que demonstra o potencial de aplicação destas em novas fontes.

\subsection{Considerações}

Analisando as disposições acima acerca das vantagens de utilização das lâmpadas halógenas com relação ao espectro de emissão, da potência radiante, que trataremos a partir de agora como irradiância, e da distribuição desta irradiância, podemos considerá-las como um tipo de fonte promissora para aplicações em fotoquimeoterapia, no entanto, essas lâmpadas possuem algumas limitações e desvantagens que serão apresentadas a seguir. 
Uma desvantagem das lâmpadas halógenas está relacionada ao fato que a alta intensidade da radiação térmica pode produzir o aquecimento do objeto sob irradiação, mas este efeito pode ser eliminado com a utilização de filtros térmicos.

Outra limitação está relacionada com o ângulo de divergência luminosa dessas lâmpadas que apresentam geralmente ângulos superiores a $23^{\circ} \circ$ que implica na utilização de lentes para convergir o feixe luminoso. No entanto, atualmente existem lâmpadas halógenas modernas que concentram sua divergência luminosa em pequenos ângulos (até $8^{\circ}$ ), que podem diminuir ou suprir essa necessidade do uso de lentes.

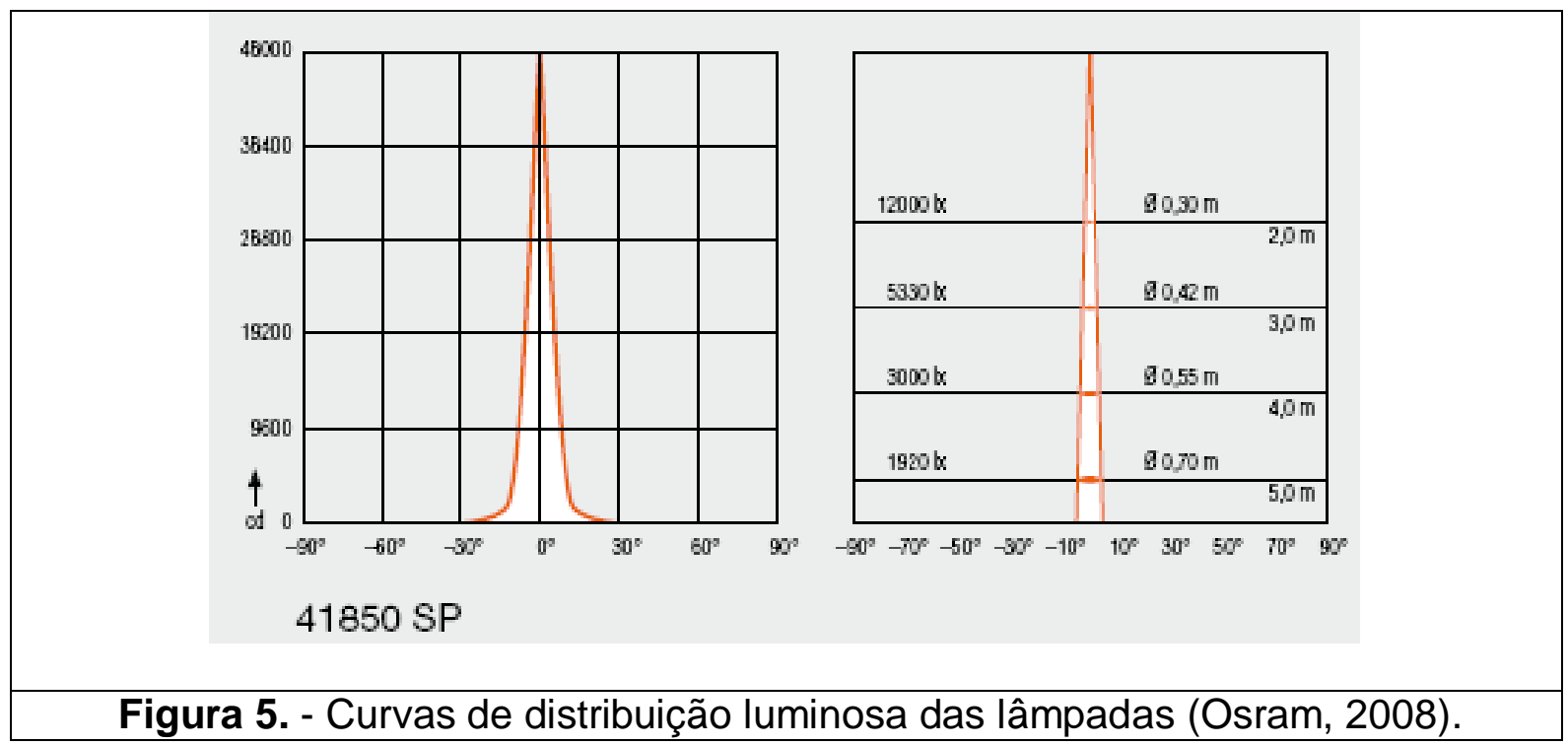

Tomando por base as vantagens, desvantagens ou limitações discutidas acima as fontes baseadas em lâmpadas halógenas podem ser promissoras na substituição das fontes atualmente utilizadas em fotobiologia e fotomedicina, no Brasil. 


\section{Capítulo 3 Processo de Desenvolvimento de Produto}

\subsection{Introdução}

Oportunidades de mercado para novos produtos têm crescido rapidamente, ocasionando o surgimento de novas empresas de base tecnológica.

O seguimento de Fotobiologia (em inglês, "Biophotonics") cujo objeto de estudo é a interação da luz com material biológico tem recebido novos e suntuosos investimentos. Abaixo apresentamos uma tabela que estima o tamanho deste mercado.

\begin{tabular}{|c|c|c|c|}
\hline \multicolumn{4}{|c|}{ Tabela 4- Dimensão do mercado de fotobiologia (Lee et al., 2007). } \\
\hline \multirow[t]{2}{*}{$\begin{array}{l}\text { Industry Segments Relevant } \\
\text { to Biophotonics }\end{array}$} & \multirow[t]{2}{*}{ Components within Segment } & \multicolumn{2}{|c|}{$\begin{array}{l}\text { Estimated Market Size } \\
\text { (in Millions of USD) }\end{array}$} \\
\hline & & \begin{tabular}{|l|l|} 
US \\
\end{tabular} & World \\
\hline Microscopes and accessories [1] & Microscopes & & 1,650 in 2004 \\
\hline Medical lasers [2] & $\begin{array}{l}\text { Laser illumination, Lasers for OCT, Surgical lasers, Dermatology lasers, } \\
\text { Cosmetic lasers, Dental lasers, Would care lasers, Lasers for low-level } \\
\text { laser, therapy, Lasers for benign prostatic, hyperplasia }\end{array}$ & $\begin{array}{l}1,554 \\
\text { in } 2004\end{array}$ & 2,390 in 2004 \\
\hline DNA sequencing [3] & DNA sequencing & & 7,800 in 2004 \\
\hline In Vitro Diagnostics [4] & $\begin{array}{l}\text { Clinic biochemistry, Immunoassays, Blood testing, Nucleic acid diag- } \\
\text { nostics, Flow cytometers }\end{array}$ & 13,170 in 2004 & 29,400 in 2004 [5] \\
\hline Endoscopes [6] & Endoscopes, (excludes visualization equipment) & 442 in 2004 & 110 in $2000[7]$ \\
\hline $\begin{array}{l}\text { Medical imaging equipment } \\
\text { [8] }\end{array}$ & $\mathrm{X}$-ray, PET, CT, MRI, ultrasound & $\begin{array}{c}6,600 \text { in } 2003 \\
1,500 \mathrm{X} \text {-ray } \\
1,400 \mathrm{MRI} \\
1,300 \text { ultrasound } \\
2,400 \mathrm{PET}+\mathrm{CT}+\text { nuclear } \\
\text { medicine etc }\end{array}$ & 14,000 in 2001 [9] \\
\hline $\begin{array}{l}\text { Patient monitoring systems } \\
{[10]}\end{array}$ & $\begin{array}{l}\text { Pulsed oximetry, IR body temperature sensors, Blood glucose moni- } \\
\text { tors, Cardiac and multi-parameter, monitoring systems with fiber optic } \\
\text { sensors, Bili light, Slit lamps, Borescopes, fiberscopes, videoscopes }\end{array}$ & 6,000 in 2003 & \\
\hline $\begin{array}{l}\text { Radiation-based therapy and } \\
\text { therapeutic imaging [11] }\end{array}$ & $\mathrm{X}$-ray and laser therapeutic radiation & 4,000 ib 2004 & \\
\hline $\begin{array}{l}\text { Adjunctive therapies: } \\
\text { photodynamic, electromag- } \\
\text { netic, radioimmunotherapy, } \\
\text { and angiogenesis inhibitors } \\
\text { [12] }\end{array}$ & PDT instrumentation and therapeutic agents & 1,700 in 2004 & \\
\hline $\begin{array}{l}\text { Biometric devices [13], [14], } \\
\text { [15] }\end{array}$ & $\begin{array}{l}\text { Face, Iris, Live Scan, Flngerprint Chips, Large-Scale AFIS Systems, } \\
\text { Hand and Finger Geometry, Retinal, Vein, Multimodal, Gait } \\
\text { Recognition, Ear, Olfactory, Lip, Nail, Skin }\end{array}$ & 270 in 2004 & 1,539 in 2005 [15] \\
\hline $\begin{array}{l}\text { ESTIMATED TOTAL } \\
\text { BIOPHOTONICS* } \\
\text { (in Millions of USD, based on } \\
\text { products above) } \\
\end{array}$ & $\$ 53,720$ & & \\
\hline
\end{tabular}


Como podemos observar o mercado para terapia fotodinâmica (PDT) em 2007 era estimado em 1,7 milhões de dólares somente no mercado americano e as estimativas de crescimento deste mercado para 2009 atingem 8,8 milhões de dólares, ou seja, o mercado deverá ser aproximadamente 5 vezes maior, como mostra a tabela abaixo.

\begin{tabular}{|c|c|c|c|c|c|}
\hline \multirow[t]{2}{*}{$\begin{array}{l}\text { Industry Segments } \\
\text { Relevant to Biophotonics }\end{array}$} & \multirow[t]{2}{*}{ Components within Segment } & \multicolumn{2}{|c|}{$\begin{array}{c}\text { Forecast } \\
\text { (in Millions of USD) }\end{array}$} & \multicolumn{2}{|c|}{$\begin{array}{c}\text { Annual Growth Rate } \\
(\mathrm{A}=\text { average, } \mathrm{C}=\text { compound) }\end{array}$} \\
\hline & & US & World & US & World \\
\hline $\begin{array}{l}\text { Microscopes and } \\
\text { accessories }\end{array}$ & Microscopes & & $\begin{array}{l}2,770 \\
\text { in } 2009\end{array}$ & & $\begin{array}{c}11 \% \\
\text { AAGR }\end{array}$ \\
\hline Medical lasers & $\begin{array}{l}\text { Laser illumination, Lasers for OCT, Surgical lasers, } \\
\text { Dermatology lasers, Cosmetic lasers, Dental lasers, } \\
\text { Would care lasers, Lasers for low-level laser, therapy, } \\
\text { Lasers for benign prostatic, hyperplasia }\end{array}$ & $\begin{array}{c}2,086 \\
\text { in } 2006\end{array}$ & $\begin{array}{l}3,209 \\
\text { in } 2006\end{array}$ & $\begin{array}{c}12 \% \\
\text { CAGR } \\
2003-2006\end{array}$ & $\begin{array}{c}12 \% \\
\text { CAGR } \\
2003-2006\end{array}$ \\
\hline DNA sequencing & DNA sequencing & & $\begin{array}{l}17,500 \\
\text { in } 2009 \\
\end{array}$ & & $\begin{array}{l}17.6 \% \\
\text { AAGR }\end{array}$ \\
\hline In Vitro Diagnostics & $\begin{array}{l}\text { Clinic biochemistry, Immunoassays, Blood testing, } \\
\text { Nucleic acid diagnostics, Flow cytometers }\end{array}$ & $\begin{array}{r}17,700 \\
\text { in } 2009\end{array}$ & & $\begin{array}{c}6.1 \% \\
\text { in } 2004\end{array}$ & $\begin{array}{c}5 \% \\
\text { in } 2005\end{array}$ \\
\hline Endoscopes & Endoscopes (excludes visualization equipment) & $\begin{array}{l}513.5 \\
\text { in } 2012\end{array}$ & & $\begin{array}{l}1.9 \% \text { CAGR } \\
2005-2012\end{array}$ & \\
\hline $\begin{array}{l}\text { Medical imaging } \\
\text { equipment }\end{array}$ & $\mathrm{X}$-ray, PET, CT, MRI, ultrasound & $\begin{array}{c}9,500 \\
\text { in } 2008 \\
1,900 \mathrm{X} \text {-ray } \\
1,775 \mathrm{MRI} \\
1,775 \text { ultrasound } \\
4,050 \text { other }\end{array}$ & & $\begin{array}{c}7.6 \% \\
2003-2008 \\
4.6 \% \mathrm{X} \text {-ray } \\
5.3 \% \mathrm{MRI} \\
6.2 \% \text { ultrasound } \\
11.2 \% \text { other } \\
\text { (PET more than } 3 \mathrm{X} \text { ) }\end{array}$ & $\begin{array}{l}7 \% \text { through } \\
2007\end{array}$ \\
\hline Patient monitoring systems & $\begin{array}{l}\text { Pulsed oximetry, IR body temperature sensors, Blood } \\
\text { glucose monitors, Cardiac and multi-parameter, } \\
\text { monitoring systems with fiber optic sensors, Bili light, } \\
\text { Slit lamps, Borescopes, fiberscopes, videoscopes }\end{array}$ & $\begin{array}{l}8,200 \\
\text { in } 2008\end{array}$ & & $6.7 \%$ & \\
\hline $\begin{array}{l}\text { Radiation-based therapy } \\
\text { and therapeutic imaging }\end{array}$ & X-ray and laser therapeutic radiation & $\begin{array}{c}5,700 \\
\text { in } 2009\end{array}$ & & $7.6 \%$ AAGR & \\
\hline $\begin{array}{l}\text { Adjunctive therapies: } \\
\text { photodynamic, electromag- } \\
\text { netic, radioimmunotherapy, } \\
\text { and angiogenesis inhibitors }\end{array}$ & PDT instrumentation and therapeutic agents & $\begin{array}{c}8,800 \\
\text { in } 2009\end{array}$ & & $39.2 \%$ & \\
\hline
\end{tabular}

Neste trabalho utilizamos algumas técnicas empregadas no desenvolvimento de produtos de modo a direcionar o desenvolvimento da nossa fonte. 
Muitos projetos de pesquisa desenvolvidos na universidade não resultaram num avanço tecnológico ou num novo produto, pelo fato de serem realizados sem levar em conta as necessidades e as capacidades de uma empresa ou de um mercado em absorver o produto ou a tecnologia estudada. Procuramos aplicar neste trabalho um método usualmente utilizado nas empresas de modo a promover a competitividade e sustentabilidade do produto desenvolvido.

A primeira etapa do desenvolvimento de produtos consiste do planejamento estratégico de produtos (Rozenfeld et al., 2006; Cooper, 1993; Clark; Wheelwright, 1993).

Um dos métodos existentes é o Technology Roadmapping (TRM), o qual permite a elaboração de um planejamento estratégico de produtos relacionando as estratégias de negócio, de mercado, de produtos e de tecnologias ao longo do tempo (Phaal et al., 2001; Albright, Kappel, 2003; Garcia, Bray 1997; Whalen, 2007).

\subsection{TRM}

O Technology Roadmapping é um método cujo objetivo principal é auxiliar no planejamento estratégico de desenvolvimento de mercado, produto e tecnologia, de maneira integrada ao longo do tempo (Neto, 2005). 


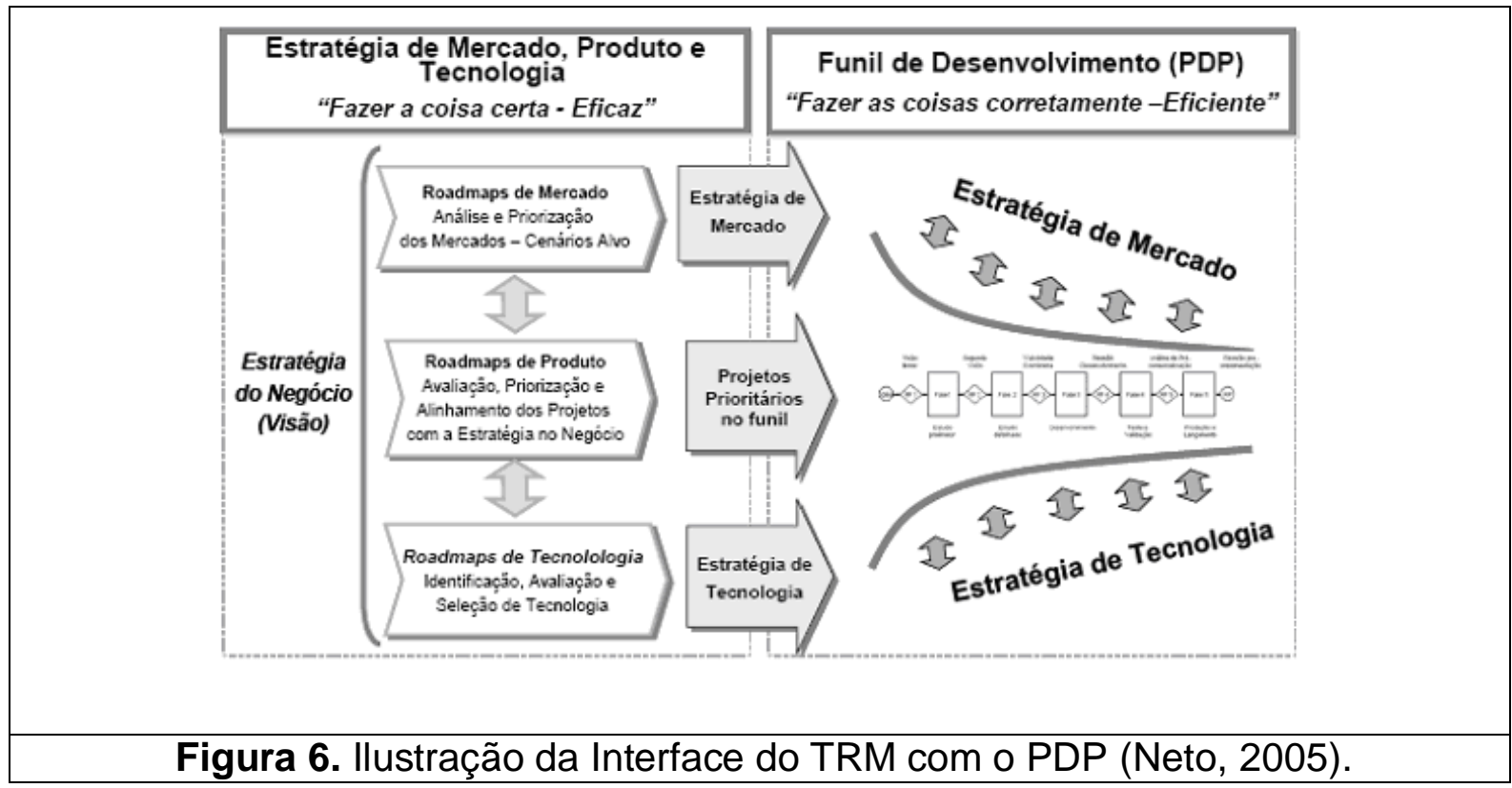

\subsection{Tipos de Mapas (Roadmaps)}

Existem inúmeros formatos de mapas, na prática cada empresa adota os que Ihe são mais convenientes. Na figura abaixo estão representados os diferentes tipos de mapas classificados de acordo com seu propósito e formato. 


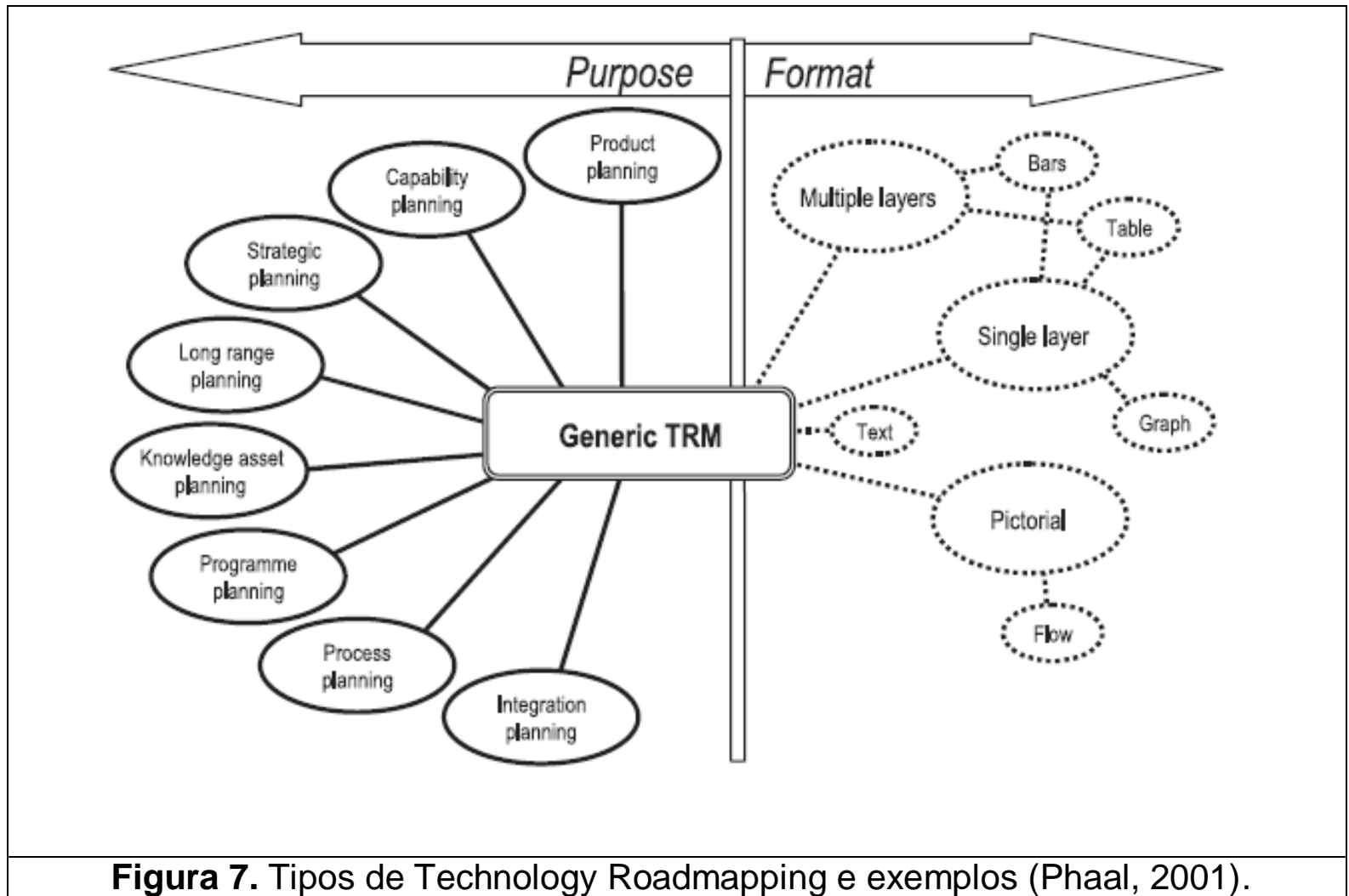

Figura 7. Tipos de Technology Roadmapping e exemplos (Phaal, 2001).

A seguir temos uma classificação que foi desenvolvida por (Kappel, 2001) que ajuda a caracterizar e compreender as variações dos "roadmaps".

Podemos dividir os "roadmaps" em quatro grandes áreas:

- "Roadmaps" de Ciência/Tecnologia: visam compreender melhor o futuro, identificando tendências, gerando previsões e definindo metas de desenvolvimento para o setor;

- "Roadmaps" de Indústria: objetivam estabelecer as expectativas de desenvolvimento da tecnologia em termos de custo e desempenho para a competitividade de um setor; 
- "Roadmaps" de Produtos/Tecnologia: buscam alinhar as decisões de desenvolvimento de produto com as tendências de mercado e de tecnologia de uma empresa; e

- "Roadmaps" de Produto: objetivam articular a direção e o cronograma da evolução de um produto e/ou famílias de produtos de uma empresa.

Neste trabalho desenvolvemos os roadmaps de produto, visto que esses são os que mais se adéquam ao objetivo, que é desenvolver uma fonte luminosa, ou seja, um produto.

\section{Capítulo 4 Materiais e métodos}

\subsection{Testes das lâmpadas}

\subsubsection{Critério de seleção das lâmpadas halógenas}

Para dar inicio a construção do primeiro protótipo foi estabelecido o critério de seleção das lâmpadas halógenas. Este critério era regido pelos itens enumerados abaixo:

1- Potência elétrica: quanto maior a potência elétrica de uma lâmpada, maior será sua irradiância, o que representa, na prática, em fotoquimeoterapia a administração de uma mesma dose num menor tempo. Por outro lado uma grande potência elétrica produz, efeitos colaterais como grande consumo de 
energia elétrica e especialmente grande emissão de radiação térmica, o que pode exigir o uso de materiais que suportem elevados valores de temperatura, ou caso necessário, a criação de sistemas de resfriamento dos mesmos.

2- Refletor Integrado: de modo a simplificar a construção do protótipo, pois se fosse escolhida uma lâmpada, sem refletor, teríamos que projetar e executar a construção do mesmo ou, comprá-lo de terceiros o que implicaria num excessivo aumento de custo, e sem necessidade pois existem lâmpadas disponíveis no mercado com refletores de alta qualidade.

3- Voltagem padrão: simplificar a construção do protótipo e reduzir custos, pois se a lâmpada escolhida tivesse a mesma voltagem da rede, não seria necessário o uso de transformador.

4- Divergência luminosa: quanto menor o ângulo de divergência luminosa, mais fácil é concentrar o feixe luminoso;

5- Dimensões reduzidas: quanto menor a lâmpada menor a fonte como um todo representando um aumento na mobilidade e portabilidade da mesma;

6- Alta durabilidade: quanto maior a vida útil da lâmpada, menor a necessidade de troca, reduzindo custos de manutenção;

7- Baixo custo: quanto menor o custo da lâmpada, menor o custo final do produto promovendo sua competitividade;

8- Disponibilidade no Brasil: facilidade de reposição em caso de troca.

Resumindo foram selecionadas as lâmpadas que melhor se adequaram aos critérios estabelecidos acima. 
As lâmpadas foram selecionadas dos catálogos dos principais fabricantes (Osram, 2008; Philips, 2008), cujos produtos estão disponíveis no Brasil.

\subsubsection{Descrição dos equipamentos utilizados}

\subsubsection{Medidor de Intensidade luminosa Spectra Physics 407 A}

O medidor Spectra Physics 407A é composto por medidor analógico e por uma cabeça de detecção térmica.

Os detectores térmicos convertem luz em calor e este em sinal elétrico. Este detector é classificado como "thermopile", ou seja, é um conjunto de pares de junções térmicas conectadas em série. Estas junções são constituídas por diferentes metais.os quais apresentam dependência do potencial elétrico da junção com a temperatura. Essa dependência é devida a diferença nas propriedades eletrônicas do estado sólido dos metais (Efeito Seebeck).

Este medidor tem a capacidade de medir de $5 \mathrm{~mW}$ até $30 \mathrm{~W}$, num intervalo de $250 \mathrm{~nm}$ até $11 \mu \mathrm{m}$, sendo que a densidade máxima que pode ser medida é de $20 \mathrm{~kW} / \mathrm{cm}^{2}$, sendo que a área do detector é de $2,54 \mathrm{~cm}^{2}$ (Spectra Physics, 1997). 


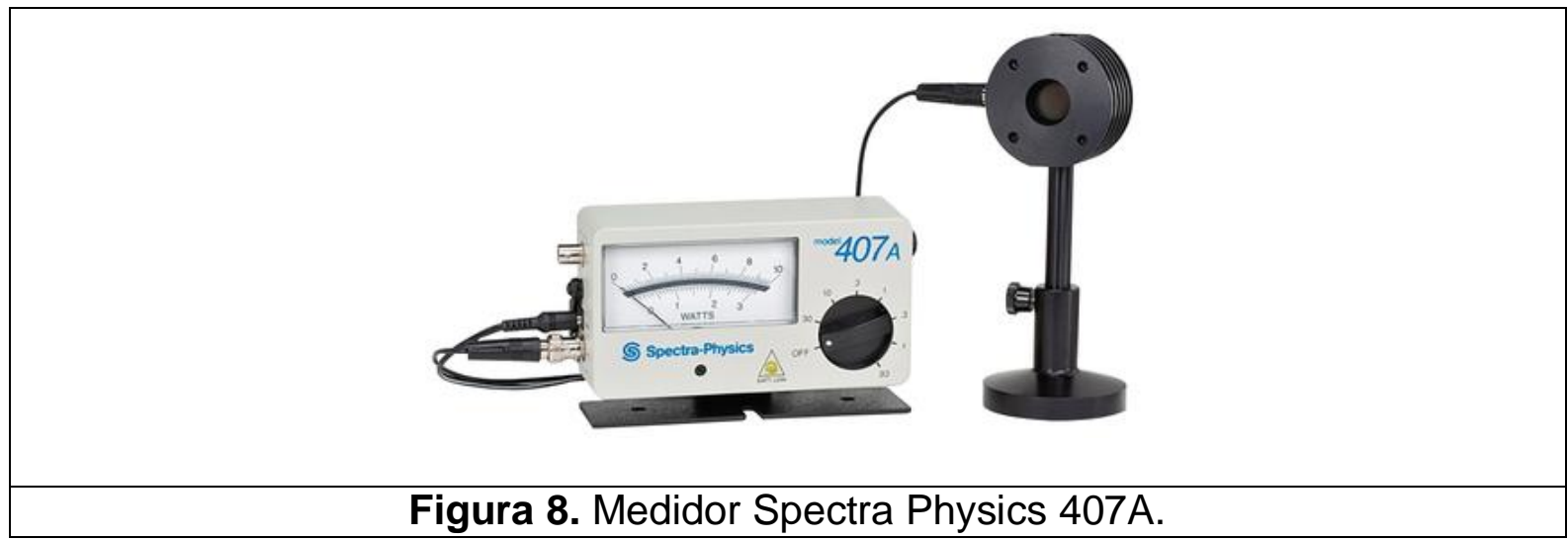

\subsubsection{Espectrômetro CVI-240A}

O espectrômetro CVI-SM240A é uma unidade baseada em CCD. Ele possui conector para fibra ótica e uma interface com o computador.

Ele é capaz de realizar medidas num intervalo de 200 a $1050 \mathrm{~nm}$ com resolução de 0,3 a 10nm.

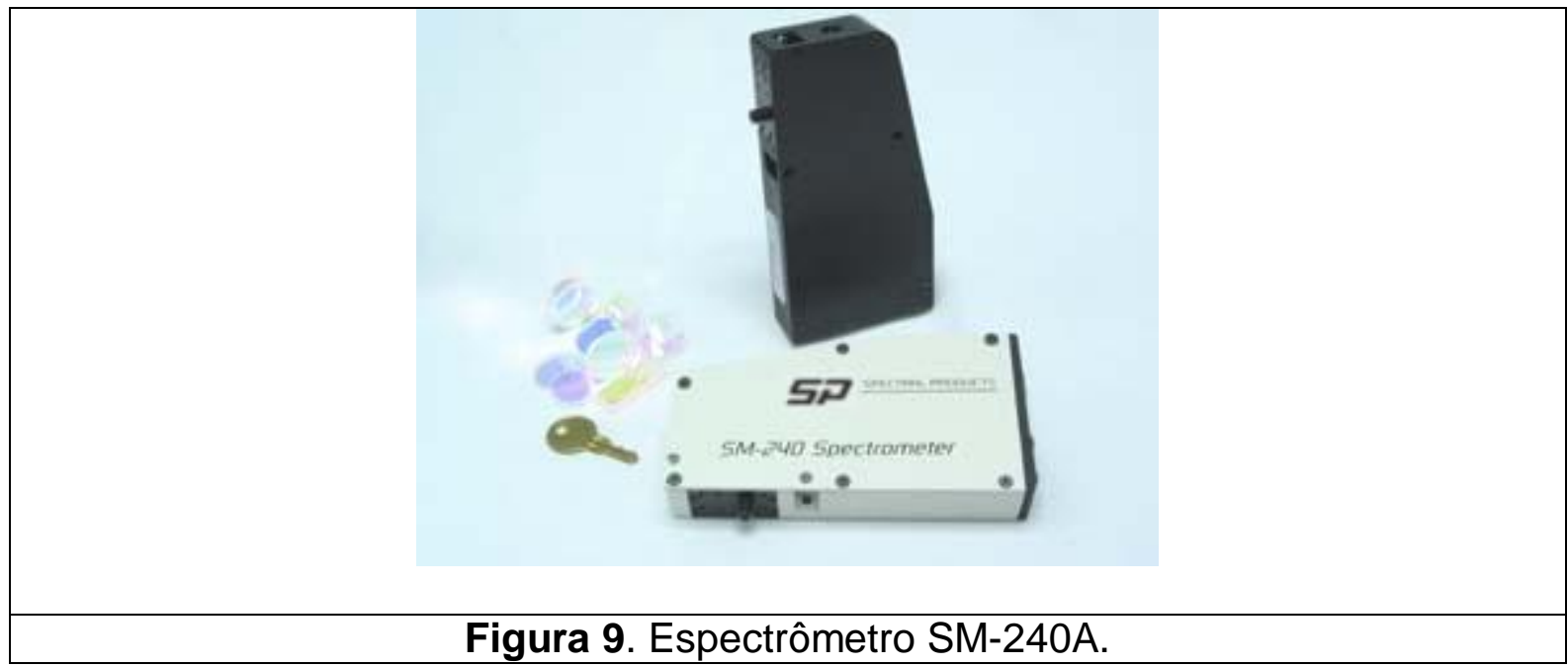

Usamos este espectrômetro para monitorar os espectros da emissão das lâmpadas. 


\subsubsection{Espectrofotômetro Beckman Coulter DU640}

Este é um espectrofotômetro produzido pela empresa "Beckman Coulter" (Estados Unidos) que permite medir a transmitância e absorbância dos materiais na região espectral de 190 até $1100 \mathrm{~nm}$.

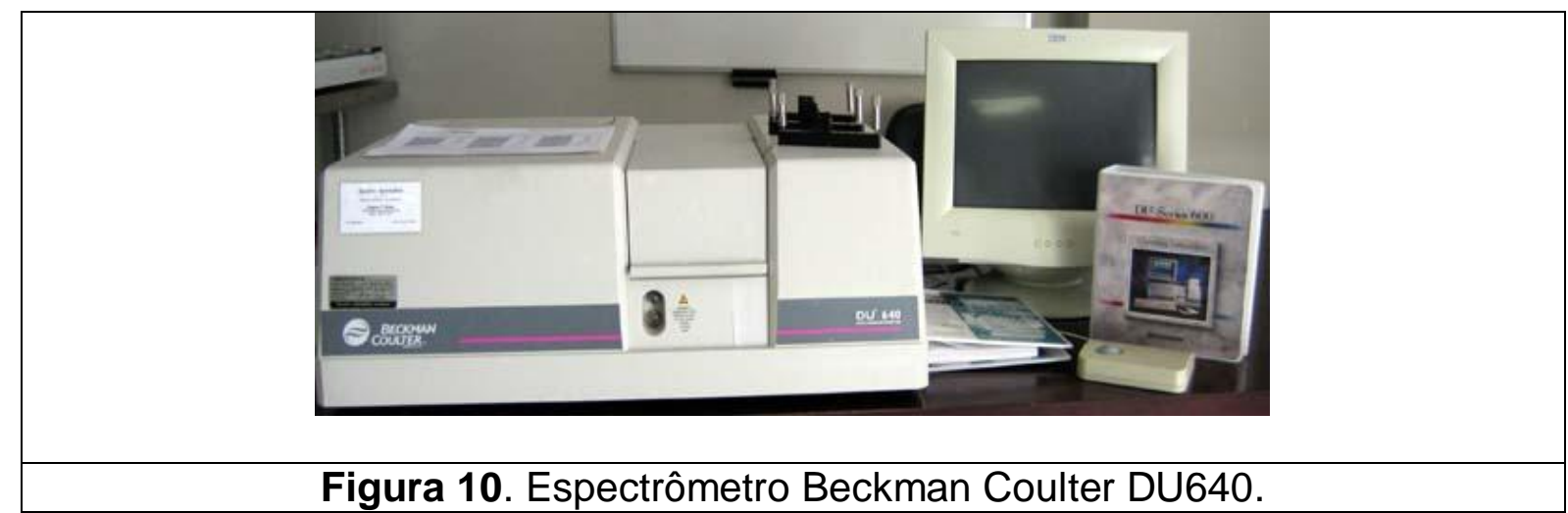

Neste trabalho este equipamento foi utilizado somente nos testes dos filtros térmicos.

\subsubsection{Termômetros}

Nos experimentos com medidas da temperatura utilizamos dois tipos de termômetro: o termômetro Minipa MT-511 e um termômetro de mercúrio para laboratórios.

O primeiro termômetro é uma unidade que funciona como termopar, é digital e possui faixa de medida de -200 a $1370^{\circ} \mathrm{C}$ com a precisão de $1^{\circ} \mathrm{C}$.

O segundo é uma termômetro de coluna de mercúrio que possui faixa de medida de -15 a $205^{\circ} \mathrm{C}$ com a precisão de $1^{\circ} \mathrm{C}$. 


\subsubsection{Sistema $x y$.}

Devido à necessidade se efetuar diversas medidas em diferentes lâmpadas e posteriormente, de diferentes protótipos em dois eixos distintos, longitudinal e axial, foi desenvolvido para este trabalho um sistema xy.

Esse sistema xy possui escala em centímetro no eixo longitudinal, com amplitude máxima de $50 \mathrm{~cm}$ e escala de meio centímetro no eixo axial com amplitude máxima de $10 \mathrm{~cm}$ para o lado positivo e $10 \mathrm{~cm}$ para o lado negativo.

O deslocamento do sistema é manual, sendo que o eixo axial e o longitudinal foram feitos em acrílico, já o suporte para o detector do medidor Spectra Physics 407A foi confeccionado em nylon.

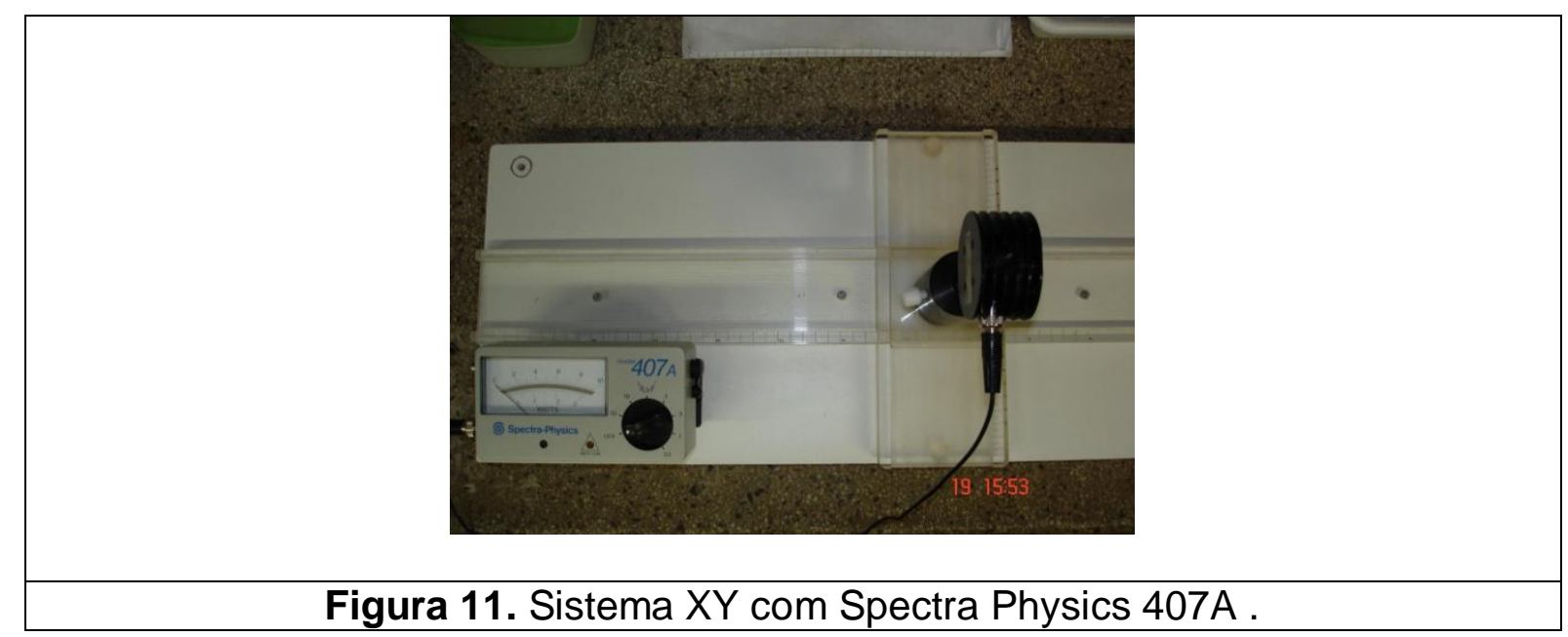

\subsubsection{Medidas dos espectros de emissão.}


Os espectros da emissão das lâmpadas foram monitorados na região espectral de 450 até $1100 \mathrm{~nm}$ utilizando espectrômetro SM-240A. Devido à diferença da sensibilidade do espectrômetro em várias regiões do espectro foi necessário calibrá-lo criando a curva de sensibilidade espectral. Para criar esta curva usamos como padrão o espectro da emissão do sol. A curva da sensibilidade $K(\lambda)$ foi calculada como:

$$
K(\lambda)=\frac{I_{\text {padr }}(\lambda)}{I_{\text {ex }}(\lambda)}
$$

em que, $I_{\text {ex }}(\lambda)$ é o espectro do sol medido experimentalmente e $I_{\text {padr }}(\lambda)$ é o espectro do sol modelado com o espectro da emissão do corpo negro em $5900 \mathrm{~K}$.

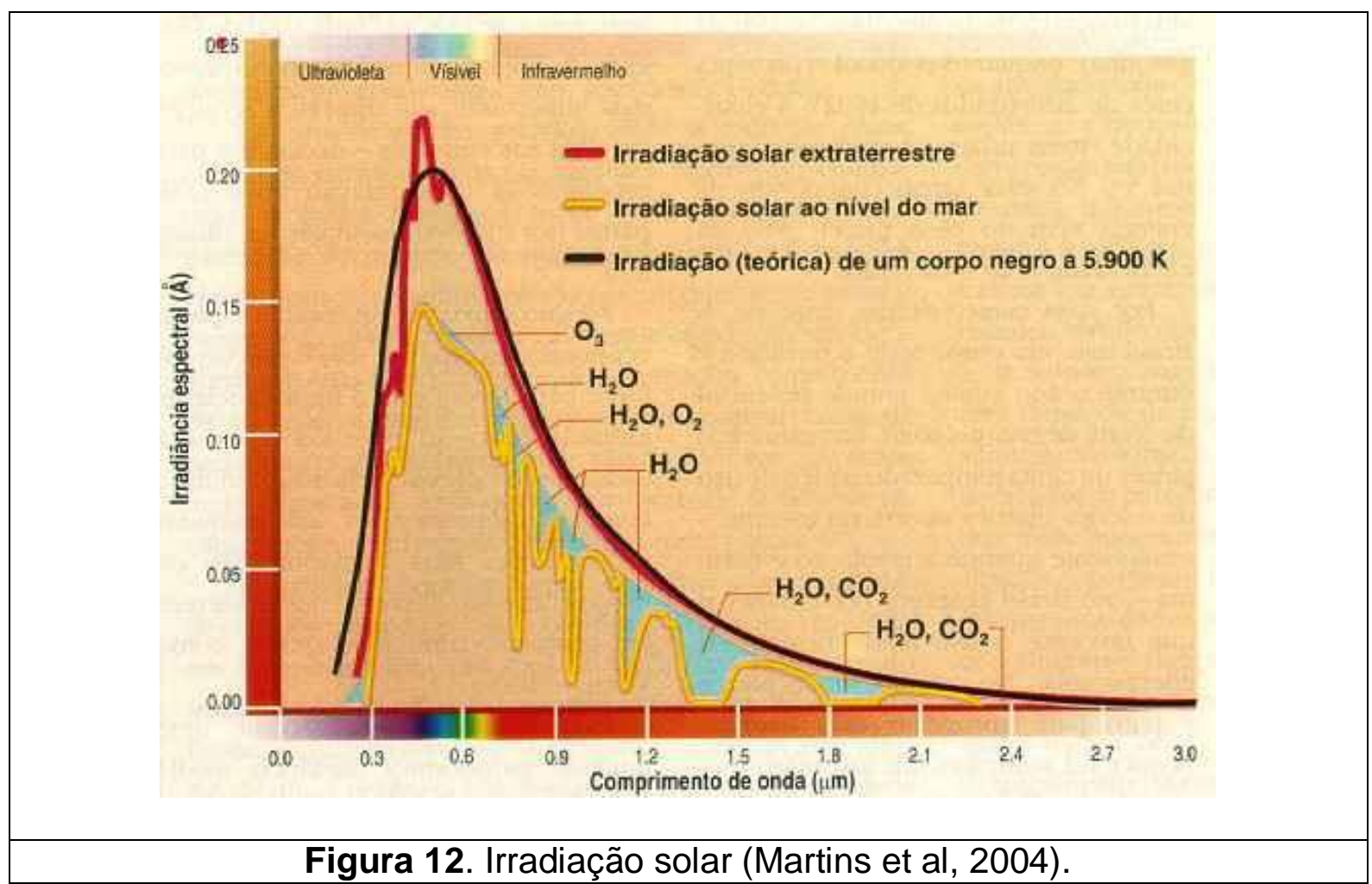

Figura 12. Irradiação solar (Martins et al, 2004). 
Devido à absorção pelos componentes de atmosfera, o espectro do sol na superfície terrestre, é diferente do espectro da emissão do corpo negro. Entretanto, na região $\lambda>450 \mathrm{~nm}$ os perfis de ambos os espectros são semelhantes. Por este motivo utilizamos no lugar do $\mathrm{l}_{\mathrm{ex}}(\lambda)$, o seu ajuste obtido pelo programa "Origin" versão 6.0 .

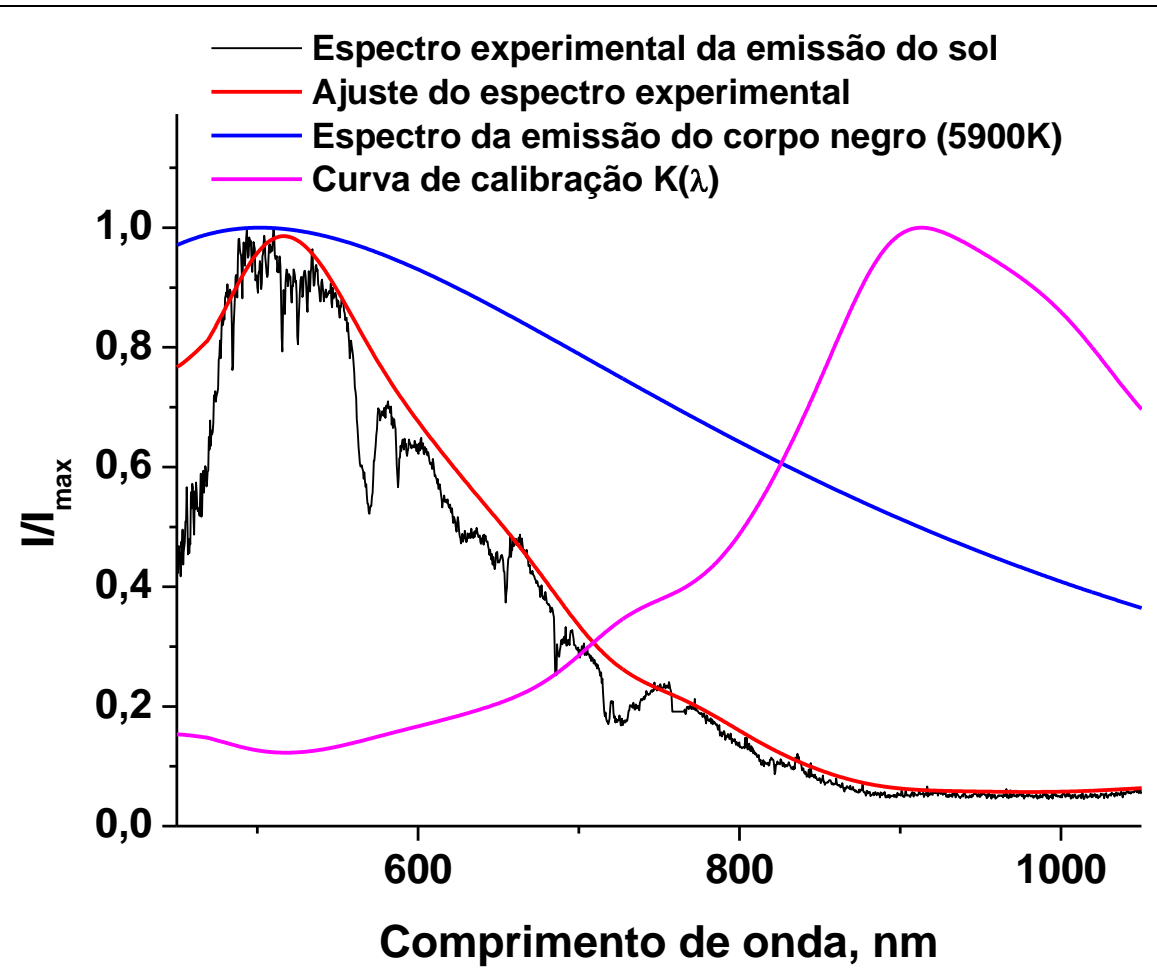

Figura 13. Curva de calibração.

\subsubsection{Medidas da distribuição espacial da irradiância.}

O sistema xy foi utilizado tanto para efetuar medidas de irradiância de novas lâmpadas, quanto para realizar essas medidas nos protótipos. 
As primeiras medidas foram feitas posicionando o detector do medidor de intensidade luminosa Spectra Physics 407A diretamente no centro do feixe luminoso da lâmpada.

Foram tomadas medidas a partir do ponto zero, o que significa que 0 detector foi posicionado junto à lâmpada e foram feitas medidas com intervalos iniciais de $1 \mathrm{~cm}$ no eixo longitudinal até a distância $15 \mathrm{~cm}$, após essa distância 0 intervalo adotado foi de $5 \mathrm{~cm}$ até completar $40 \mathrm{~cm}$ que representa a maior superfície útil do eixo longitudinal. No eixo axial as medidas foram feitas até que o detector registrasse valor nulo.

\subsection{Processo de aplicação do TRM}

A aplicação do Technology Roadmapping neste trabalho seguiu o processo denominado T-Plan (Phall et al., 2001).

O processo padrão do T-Plan sugeri 6 passos:

1. Planejamento

Esta etapa aborda os aspectos que devem ser considerados antes de se iniciar a aplicação efetiva. O T-Plan apresenta os seguintes pontos a serem analisados nesse momento: participantes, foco, customização do processo e trabalho preparatório.

2. Workshop de Mercado 
Os objetivos propostos pelo T-Plan para essa etapa são: apresentar os conceitos do TRM, apresentar o processo do T-Plan, confirmar os objetivos da empresa com a aplicação do TRM, definidos no planejamento, identificar o conjunto de dimensões de desempenho do produto, identificar e priorizar os direcionadores do mercado e do negócio para os segmentos chaves, considerar a posição estratégica, em termos de oportunidades, ameaças, forças e fraquezas e identificar lacunas no conhecimento e áreas para trabalho adicional.

\section{Workshop de Produto}

Os objetivos estabelecidos para esta etapa segundo o T-Plan são: revisar as informações provenientes da reunião de mercado, identificar os conceitos de características dos produtos que são capazes de satisfazer os direcionadores definidos, analisar a importância de cada conceito em relação aos direcionadores, considerar aspectos estratégicos do desenvolvimento de produtos, como a adoção de plataformas de produtos e identificar lacunas no conhecimento e áreas para trabalho adicional.

\section{Workshop de Tecnologia}

Os objetivos estabelecidos pelo T-Plan para esta reunião são: revisar as informações provenientes das reuniões de mercado e produto, identificar as possíveis soluções tecnológicas que serão capazes de satisfazer as características de produto, estabelecer um novo ranking com o potencial valor dessas soluções e identificar novas lacunas no conhecimento. 
5. Workshop de Elaboração do Mapa

Os objetivos estabelecidos pelo T-Plan para esta reunião são: revisar as informações provenientes das reuniões de mercado, produto e tecnologia, desenvolver o Roadmap (identificando os marcos de: mercado, estratégia, evolução de produto e das tecnologias selecionadas) e identificar novas lacunas no conhecimento e fazer um relatório do processo contendo os fatores de sucesso e as barreiras encontradas.

\section{Execução}

Nesta etapa todo planejamento é colocado em prática, e o roadmap torna-se o guia do desenvolvimento do produto.

Os passos de 1 a 5 foram aplicados com o auxilio do mestrando Maicon G. Oliveira do departamento de engenharia de produção SEP-EESC/USP , já o passo 6 foi executado com auxilio dos técnicos do departamento de física e matemática da Universidade de São Paulo.

\subsection{Testes in vitro}

Os testes in vitro serão feitos por meio de testes de fotocitotoxicidade de fotossensibilizador Photogem ${ }^{\circledR}$ em células neoplásicas: HT29 (linhagens adenocarcinoma de colo retal humano) (ATCC, 2008), sob a ação da luz, após a incubação da droga. 
Para cada experimento as amostras com culturas de células serão preparadas seguindo o protocolo adequado para cada tipo de célula.

A avaliação da morte celular será realizada através da medida da atividade mitocondrial utilizando o teste colorimétrico MTT (brometo de 3,-(4,5-dimetil-2tiazolil)2,5-difenil-2H-tetrazólico). O MTT é um composto amarelo claro em solução aquosa, que é metabolizado pelas células vivas e é transformado em um sal de coloração azul-púrpura (formazona), que pode ser quantificada espectrofotometricamente pela medida de sua absorção ótica em 540 nm (Mosmann, 1983).

Na contagem, $10 \mu \mathrm{l}$ de uma solução de MTT $(0.5 \mathrm{mg} / \mathrm{ml})$ serão adicionados em cada poço e 3h depois serão adicionados $50 \mu$ l de SDS (Dodecilsulfato de sódio). As densidades óticas das microplacas serão determinadas usando 0 Labsystem $^{\circledast}$.

Os resultados serão analisados em comparação com os seguintes grupos controle:
a) poços contendo células tratadas com FS sem serem expostas à luz,
b) poços contendo células sem FS e sem serem expostas à luz,
c) poços contendo células sem FS e expostas à luz.

Os testes in vitro foram realizados com o auxilio uma aluna de doutorado Luciana S. Murakami do grupo de fotobiofísica do DFM-FFCRP/USP. 


\section{Capítulo 5 Resultados e Discussão}

\subsection{Resultados dos testes das lâmpadas.}

\subsubsection{Resultados do critério de seleção das lâmpadas halógenas}

As lâmpadas foram encolhidas nos catálogos dos fabricantes e avaliadas segundo os critérios descritos na seção 4.1.1. Abaixo apresentamos uma tabela com a pontuação obtida por cada lâmpada.

\begin{tabular}{|c|c||c|c||c|}
\hline \multicolumn{4}{|c|}{ Tabela 6 - Resultado do critério de seleção das lâmpadas } \\
\hline $\begin{array}{c}\text { Lamp. } \\
\text { Critério }\end{array}$ & $\begin{array}{c}\text { 1-Osram } \\
\text { ENH54986 }\end{array}$ & $\begin{array}{c}\text { 2-Osram } \\
\mathbf{4 1 8 5 0 S P}\end{array}$ & $\begin{array}{c}\text { 3-FLC } \\
\text { Par30 }\end{array}$ & $\begin{array}{c}\text { Resultado } \\
\text { (duas } \\
\text { melhores) }\end{array}$ \\
\hline $\begin{array}{c}\text { Potência } \\
\text { elétrica }\end{array}$ & $250 \mathrm{~W}$ & 100W & $75 \mathrm{~W}$ & 1 e 2 \\
\hline $\begin{array}{c}\text { Refletor } \\
\text { Integrado }\end{array}$ & $\mathrm{Sim}$ & $\mathrm{Sim}$ & $\mathrm{Sim}$ & 1 , 2 e 3 \\
\hline $\begin{array}{c}\text { Voltagem } \\
\text { padrão }\end{array}$ & $\mathrm{Sim}$ & $\mathrm{Não}$ & $\mathrm{Sim}$ & 1 e 3 \\
\hline $\begin{array}{c}\text { Divergência } \\
\text { luminosa }\end{array}$ & $23^{\circ}$ & $8^{\circ}$ & $30^{\circ}$ & 1 e 2 \\
\hline $\begin{array}{c}\text { Dimensões } \\
\text { reduzidas }\end{array}$ & menor & média & maior & 1 e 2 \\
\hline $\begin{array}{c}\text { Alta } \\
\text { durabilidade }\end{array}$ & $175 \mathrm{~h}$ & $3000 \mathrm{~h}$ & $2000 \mathrm{~h}$ & 2 e 3 \\
\hline Baixo custo & maior & média & menor & 2 e 3 \\
\hline
\end{tabular}

Como podemos observar na tabela acima as lâmpadas 1 e 2 são as que mais aparecem na coluna de resultados, e portanto foram selecionadas para testes.É importante ressaltar que nesta fase nenhum teste físico, com as lâmpadas, foi efetuado, ou seja, as elas foram classificadas de acordo com os dados dos fabricantes. 


\subsubsection{Medidas do espectro com espectrômetro SM240A.}

Os espectros de emissão das lâmpadas 1 e 2 estão apresentados abaixo.

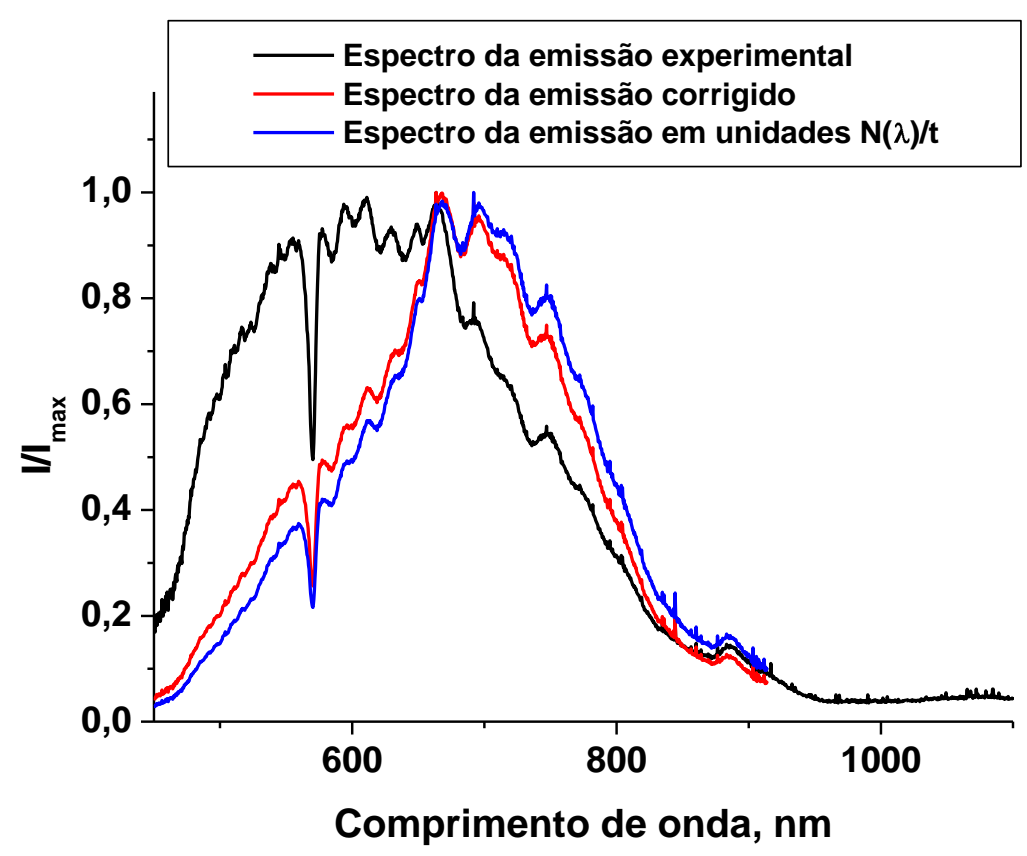

Figura 14. Espectros de emissão da lâmpada 1.

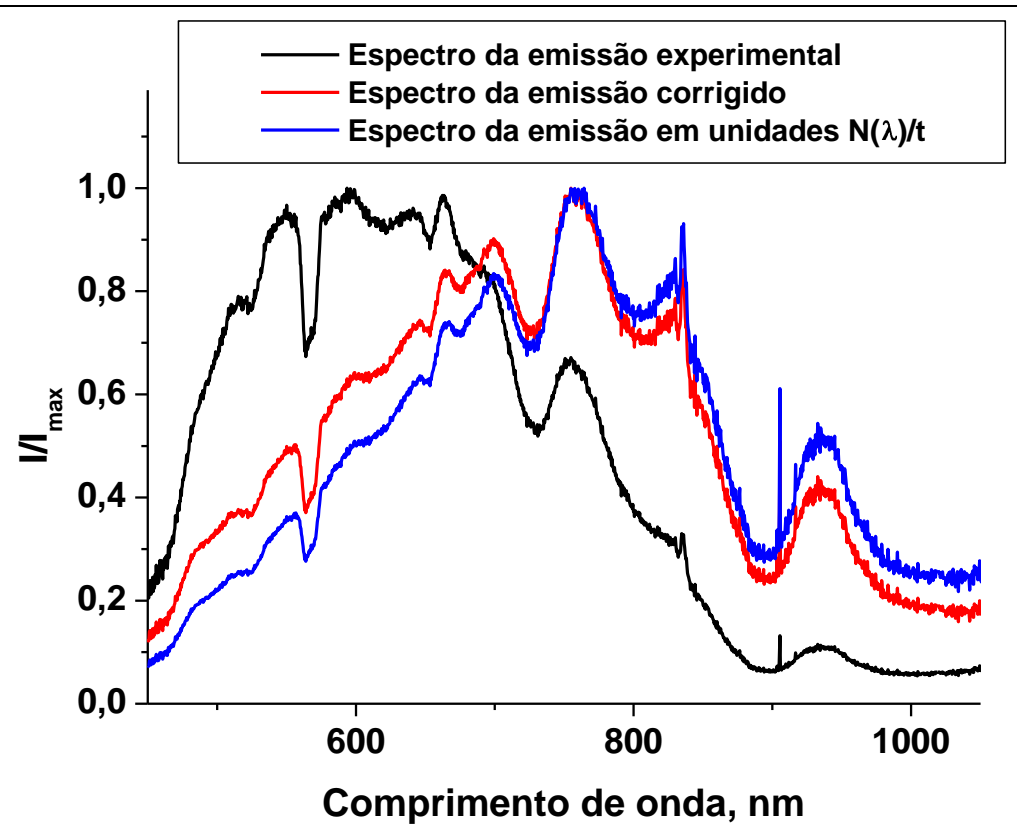

Figura 15. Espectros de emissão lâmpada 2. 
Podemos notar que os espectros de ambas as lâmpadas cobrem toda região espectral entre 450 e 900nm atingindo o máximo entre 600 e 800nm, exatamente na região da janela terapêutica. $O$ espectro da lâmpada 1 esta deslocado para comprimentos de onda menores se comparado com a lâmpada 2. Este deslocamento é devido a maior potência elétrica da lâmpada 1 e o conseqüente aumento da temperatura do seu filamento.

\subsubsection{Resultados das medidas de irradiância longitudinal}

A primeira medida foi feita posicionando o detector do medidor de intensidade luminosa Spectra Physics 407A diretamente no centro do feixe luminoso da lâmpada. Foram tomadas medidas a partir do ponto zero, ou seja, o detector foi posicionado junto à lâmpada e foram feitas medidas em função da distância, como podemos observar no gráfico abaixo.

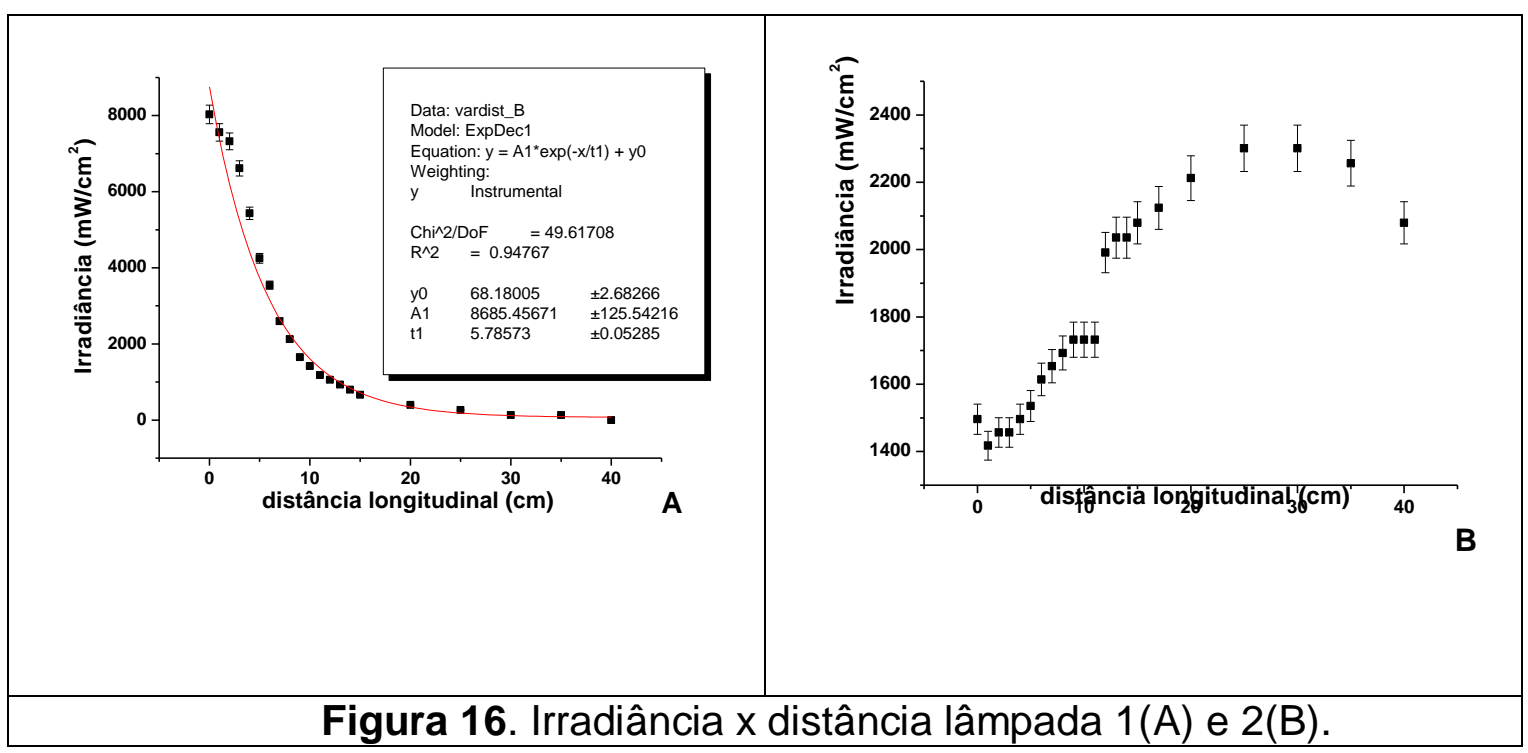


Devido a características de construção da lâmpada, existe uma capa no bulbo que faz com que todo feixe luminoso seja proveniente do refletor. Como o detector foi posicionado no centro desta lâmpada (em frente à capa do bulbo), podemos verificar no gráfico que o detector esta numa região de sombra, pois os valores de irradiância são mínimos. Ao afastar o detector da lâmpada verificamos um comportamento crescente dos valores de irradiância, até atingirmos o valor máximo (cerca de $2300 \mathrm{~mW} / \mathrm{cm}^{2}$ ), onde o detector está completamente iluminado.A partir deste ponto os valores de irradiância começam a decrescer com a distância, como é esperado teoricamente.

Para eliminarmos esse efeito indesejado utilizamos uma lente convergente nas demais medidas de irradiância da lâmpada 2. A seguir estão representadas as medidas onde, o ponto zero da distância longitudinal corresponde ao foco da lente.

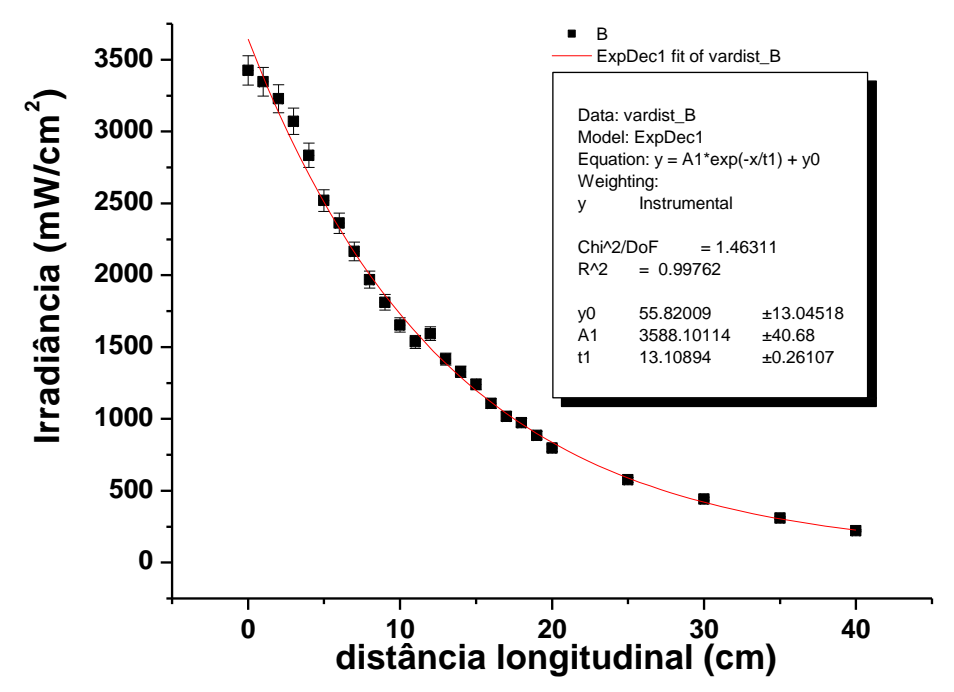

Figura 17. Irradiância x distância lâmpada 2 com lente. 
No gráfico acima podemos notar que a utilização da lente eliminou a região de sombra do detector e o gráfico apresentou o comportamento esperado de decaimento, aproximado como uma função exponencial de primeira ordem, com máximo em aproximadamente $3500 \mathrm{~mW} / \mathrm{cm}^{2}$, valores mais do que suficientes para aplicações em fotoquimeoterapia.

\subsection{Discussão dos resultados e considerações.}

Analisando as especificações técnicas da lâmpada 1 notamos que, de acordo com o fabricante esta possui abertura do feixe luminoso de 23 graus o que implica numa perda significativa de sua potência radiante com o aumento da distância. Para contornar esse problema utilizamos uma lente convergente de modo a concentrar toda a potência radiante proveniente da lâmpada.

Para a realização destas medidas estabelecemos que o ponto focal desta lente deveria ser o ponto zero, ou seja, o ponto de maior intensidade luminosa. No entanto, ao posicionar o detector, notamos um aumento significativo da temperatura do mesmo, quando comparada com as medidas sem o uso da lente, desta forma interrompemos as medidas de modo a quantificar este aumento de temperatura de modo a preservar a integridade do detector.

Ao medir a temperatura utilizando um termômetro digital (Minipa-MT511), verificamos que a temperatura no ponto focal da lente atingia aproximadamente $130^{\circ} \mathrm{C}$ com uma irradiância aproximada de $3420 \mathrm{~mW} / \mathrm{cm}^{2}$. Estes valores de 
temperatura e de irradiância estão acima dos valores limites para não causar queimaduras na pele, sendo, portanto necessária a diminuição da temperatura local (Morton et al., 2002).

Para diminuir a temperatura, sem diminuir a irradiância na parte visível do espectro, decidimos utilizar um filtro de infravermelho, pois esta parte do espectro desta lâmpada só contribui para o aumento da temperatura, visto que estes comprimentos de onda estão localizados fora da região da janela terapêutica.

Foram feitos testes com dois tipos de filtros: um filtro de vidro de infravermelho, utilizado geralmente em projetores de slide e um recipiente com água, pois água é um eficiente absorvedor de energia eletromagnética na região espectral infravermelha.

Colocamos os dois filtros no espectrômetro (Beckman Coulter DU640), sendo que o filtro de vidro foi colocado diretamente no feixe de luz e a água foi colocada em uma cubeta de acrílico. Os resultados estão expressos no gráfico abaixo. 


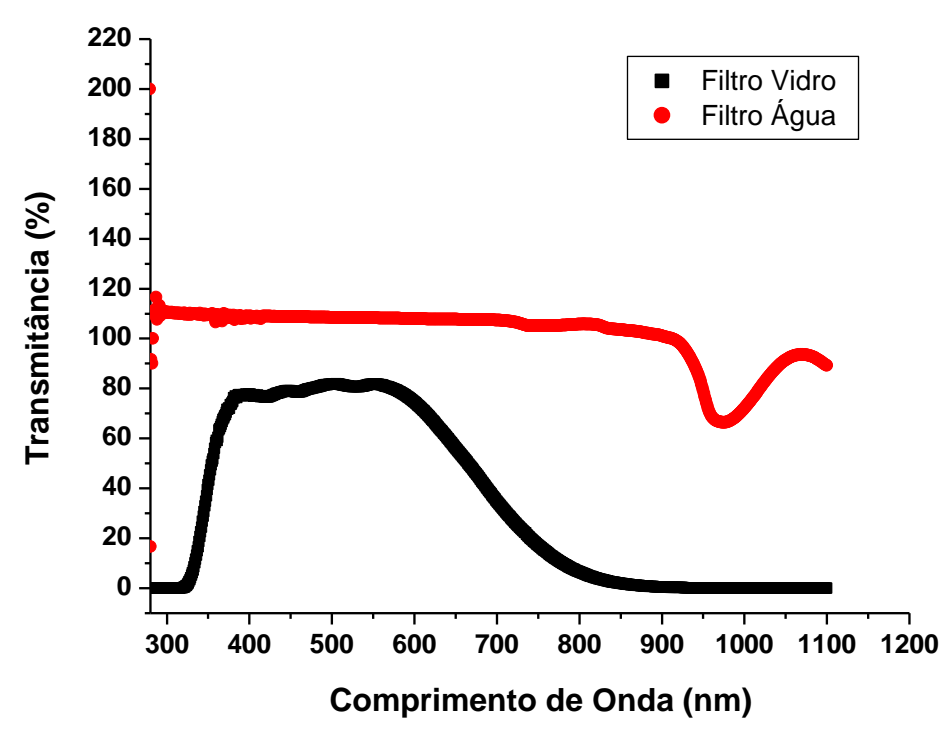

Figura 18. Espectro de transmitância do filtro de vidro e do filtro de água.

Analisando gráfico acima chegamos à conclusão que o melhor filtro de infravermelho, que poderíamos utilizar, seria a água, pois ela não possui absorção na região até $\lambda>900 \mathrm{~nm}$, enquanto que a absorção do filtro térmico de vidro começa em $\lambda \approx 600 \mathrm{~nm}$.

No entanto mais um problema de aquecimento deveria ser resolvido, pois, devido às características de construção da lâmpada 1, ela dissipa uma grande quantidade de calor ao redor. A temperatura no refletor, medida com um termopar, atingiu valores próximos a $250^{\circ} \mathrm{C}$, o que causaria problemas de construção para 0 protótipo, pois os materiais envolvidos deveriam então suportar valores elevados de temperatura.

Neste ponto questionamos se esta lâmpada seria adequada para o projeto, pois apesar de oferecer valores de irradiância mais do que suficientes para a 
aplicação a que se destina existiam problemas relacionados à temperatura excessiva que poderiam inviabilizar a construção do protótipo.

Com relação à dissipação de calor, a lâmpada 2 é muito mais eficiente, pois alem de possuir uma maior área de dissipação a potência elétrica é menor resultando numa menor dissipação de energia térmica.

Medidas no foco da lente com lâmpada 2, mostraram a irradiância $\approx$ $3500 \mathrm{~mW} / \mathrm{cm}^{2}$, que é mais que suficiente para aplicação em PDT, e temperatura $\approx$ $130^{\circ} \mathrm{C}$, o que ainda justifica o uso do filtro térmico.

Outro ponto a ser analisado é que como a lâmpada 1 possui uma grande divergência $\left(23^{\circ}\right)$ comparada a lâmpada $2\left(8^{\circ}\right)$ devemos posicionar a lente muito próximo da lâmpada 1 de modo a abranger todo feixe luminoso. Esta aproximação causa um problema relacionado ao aquecimento excessivo da lente. Por outro lado, neste caso é necessário usar uma lente com distância focal bem curta, o que dificulta a construção da fonte.

Devido às dificuldades de construção que poderiam estar associadas a as altas temperaturas atingidas pela lâmpada 1 e a obtenção de uma lente especifica para esta aplicação, resolvemos optar pela lâmpada 2 mesmo sabendo que a irradiância desta é em termos efetivos cerca de 1/3 da lâmpada1.

No entanto sabemos que os valores de irradiância medidos na lâmpada 2 ainda são mais do que suficientes para as aplicações a que se destinam. Além 
disso, se compararmos o tempo de vida médio das lâmpadas 1 e 2, podemos notar, que, segundo o fabricante, a lâmpada 1 tem vida média de $175 \mathrm{~h}$ contra 3000h da lâmpada 2, o que na prática significa uma maior durabilidade do equipamento sem necessidade de manutenção.

Neste ponto do trabalho optamos por utilizar a lâmpada 2 e portanto faremos a seguir sua caracterização.

\subsection{Caracterização da lâmpada 2}

Abaixo temos um gráfico que resume os resultados obtidos com os testes da lâmpada 2, com relação as medidas de irradiância longitudinal e axial .

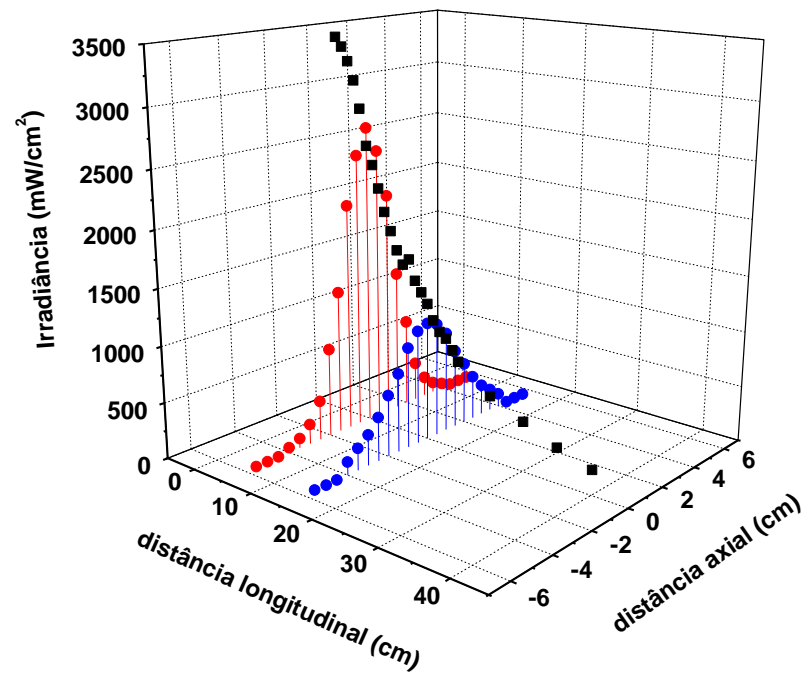

Figura 19. Irradiância x distância lâmpada 2. 
Podemos observar no gráfico acima que os valores de irradiância em função da distância longitudinal sofreram redução significativa como era esperado, visto que as lâmpadas 1 e 2 possuem potências elétricas bem distintas, 250W e 100W respectivamente.

Com relação à distribuição espacial da área irradiada tivemos uma redução da área de tratamento, devido ao fato da lâmpada 2 apresentar, segundo o fabricante, divergência luminosa de 8 graus em quanto a lâmpada 1 apresenta divergência de 23 graus. No entanto os valores de irradiância e da área de tratamento medidos na lâmpada 2 continuam sendo mais do que suficientes para aplicações em fotobiologia e na fotomedicina.

Abaixo temos o espectro de emissão da lâmpada 2, medido com 0 espectrômetro SM-240A, sem e com filtros térmicos.

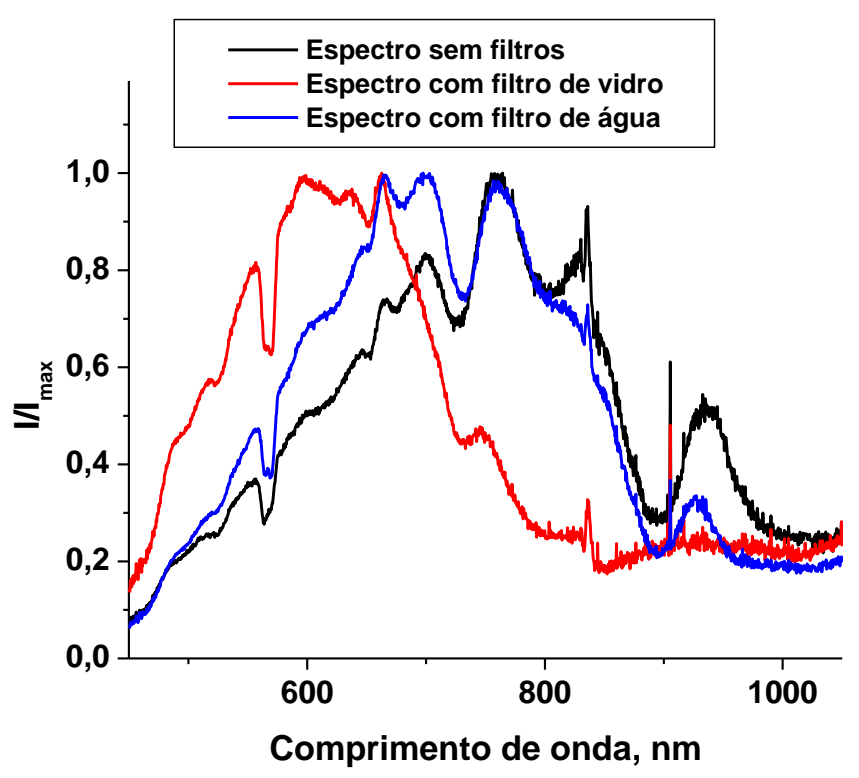

Figura 20. Espectro da emissão $\mathrm{N}(\lambda)$ da lâmpada 2 sem e com filtros térmicos. 
Como podemos observar o filtro de vidro alem de remover parte do espectro que é desnecessária e provoca aquecimento, remove também parte do espectro na região entre 700 e 800nm útil para aplicações na fotobiologia e na fotomedicina. Podemos observar também que o filtro de água preserva toda essa região sendo, portanto mais adequado para este tipo de aplicação.

Chegamos então ao esquema ótico do primeiro protótipo que seria formado pela lâmpada 2, uma lente convergente e um filtro térmico de água.

\subsection{Construção do Protótipo HLS1}

\subsubsection{Esquema geométrico}

A geometria do refletor da lâmpada 2 e a distância focal da lente convergente e sua posição determinam a posição da imagem do filamento, ou seja,

o ponto onde os raios emitidos se cruzam. É necessário saber a posição deste ponto e o ângulo de cruzamento para definir a posição do filtro térmico para que suas aberturas na entrada e na saída não limitem a intensidade da fonte.

Para calcular a posição da imagem utilizaremos a equação da lente:

$$
\frac{1}{f}=\frac{1}{s}+\frac{1}{s^{\prime}}
$$

onde $\boldsymbol{f}$ é a distância focal da lente, $\boldsymbol{s}$ é a distância do objeto a lente e $\boldsymbol{s}^{\prime}$ é a distância da imagem.

Como os valores de $\boldsymbol{f}$ e $\boldsymbol{s}$ são conhecidos, podemos calcular através da equação da lente o valor de $s^{\prime}=163,9 \pm 0,5 \mathrm{~mm}$. 


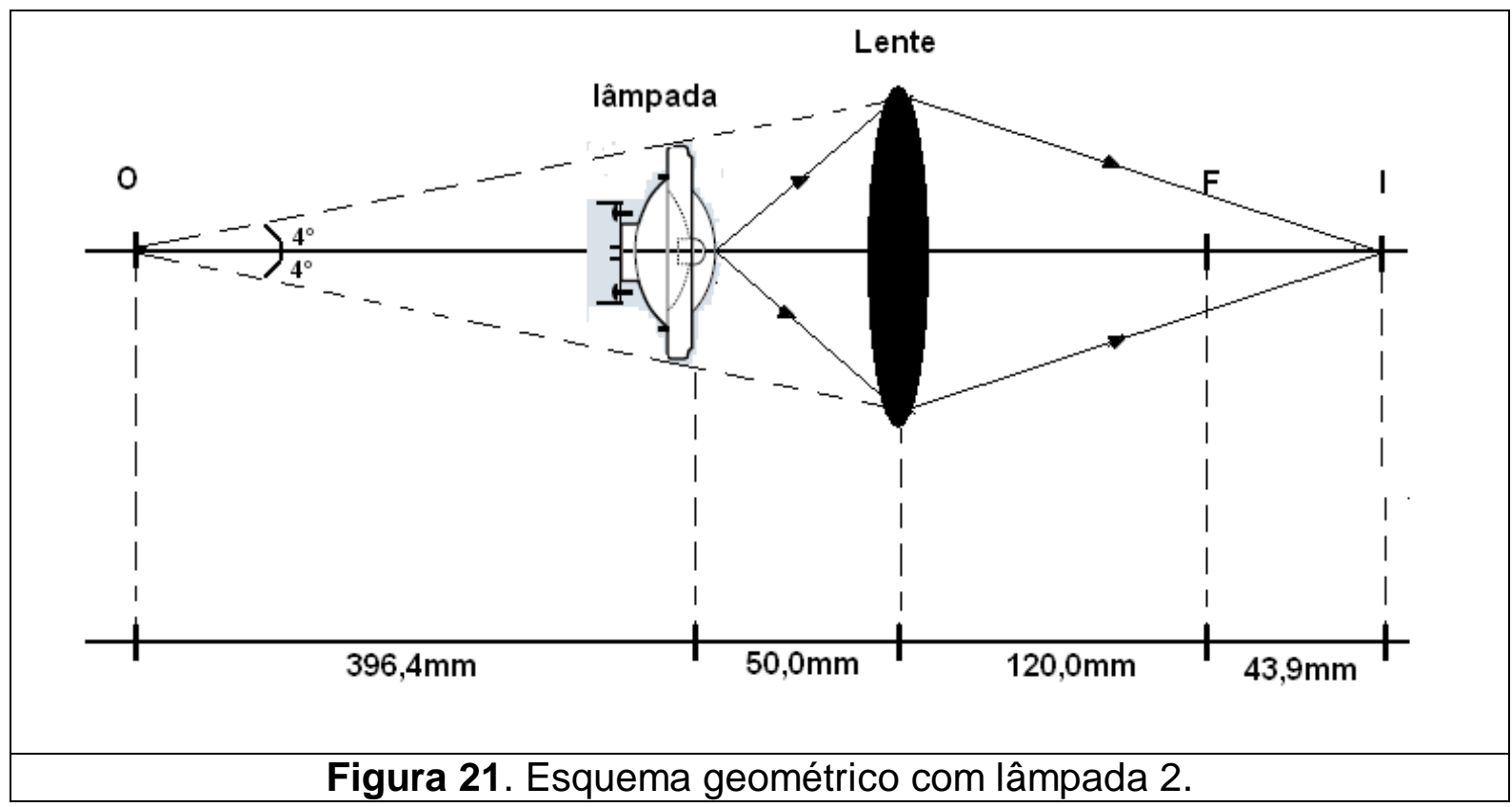

Os raios das aberturas do filtro térmico são $r=20 \pm 0,1 \mathrm{~mm}$ e seu comprimento (distância entre aberturas da entrada e da saída) é I= $80 \pm 0,1 \mathrm{~mm}$. Fixando a distância entre a lente e a fonte em $50 \pm 0,1 \mathrm{~mm}$, temos que a distância mínima entre a lente e o filtro deve ser $89,9 \pm 0,1 \mathrm{~mm}$ e a máxima é $163,9 \pm 0,1 \mathrm{~mm}$. Estes valores determinam as possíveis variações da geometria da construção da fonte.

\subsubsection{Determinação do esquema ótico}

A determinação do esquema ótico teve por base o esquema geométrico discutido no tópico anterior. 


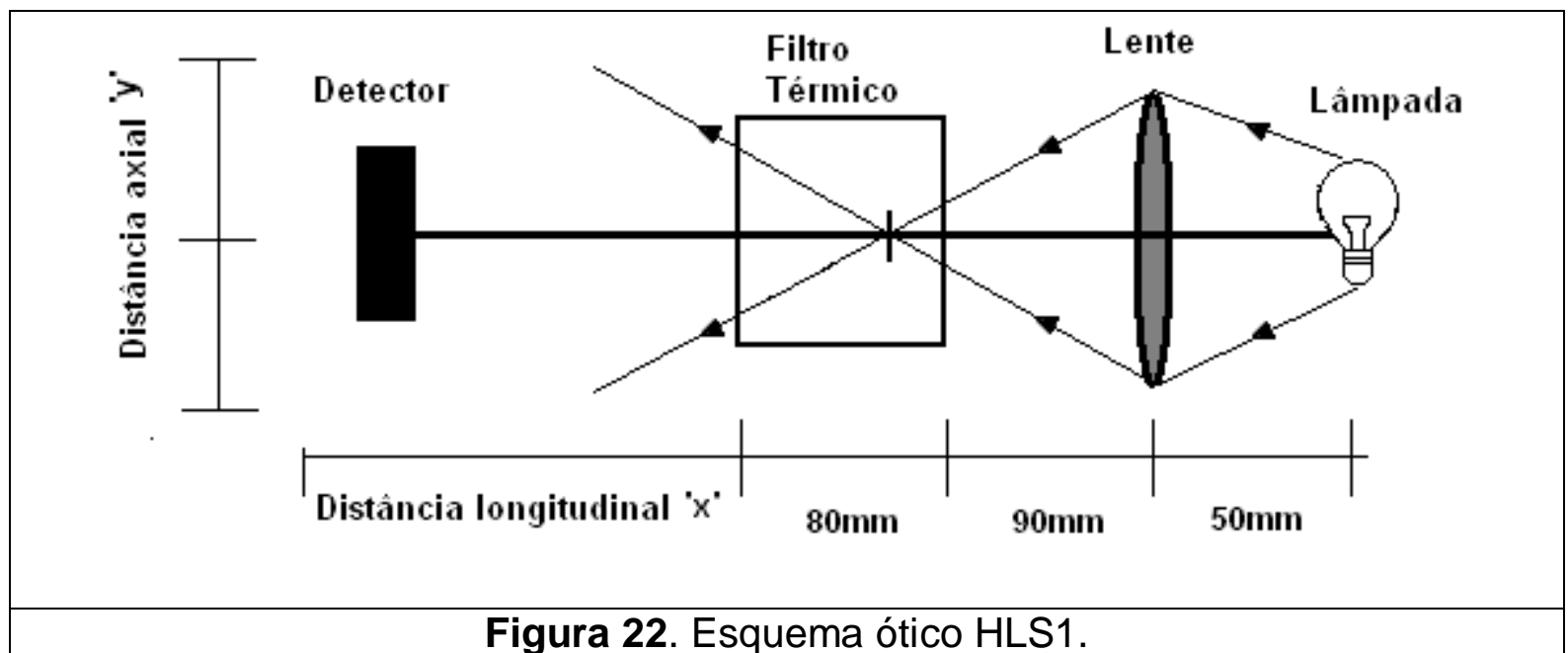

Após a determinação do esquema ótico optamos por começar a construção do protótipo em partes independentes de modo a facilitar a construção e possíveis alterações de projeto.

O equipamento que daqui em diante será denominado "HLS" (do inglês, Halogen Light Source) seguido por um número que indica o número da versão do protótipo (exemplo: HLS1 é a primeira versão do protótipo). Ele é composto pelas seguintes partes:

\section{Lâmpada}

A lâmpada selecionada é fabricada pela Osram, está identificada pelo número de modelo: $41850 \mathrm{SP}$ e possui de acordo com o fabricante: refletor de alumínio facetado, facho de luz preciso e uniforme, intensidade luminosa elevada (48000cd), filtro UV através do bulbo de quartzo, divergência luminosa de $8^{\circ} \mathrm{e}$ potência elétrica de 100W. 


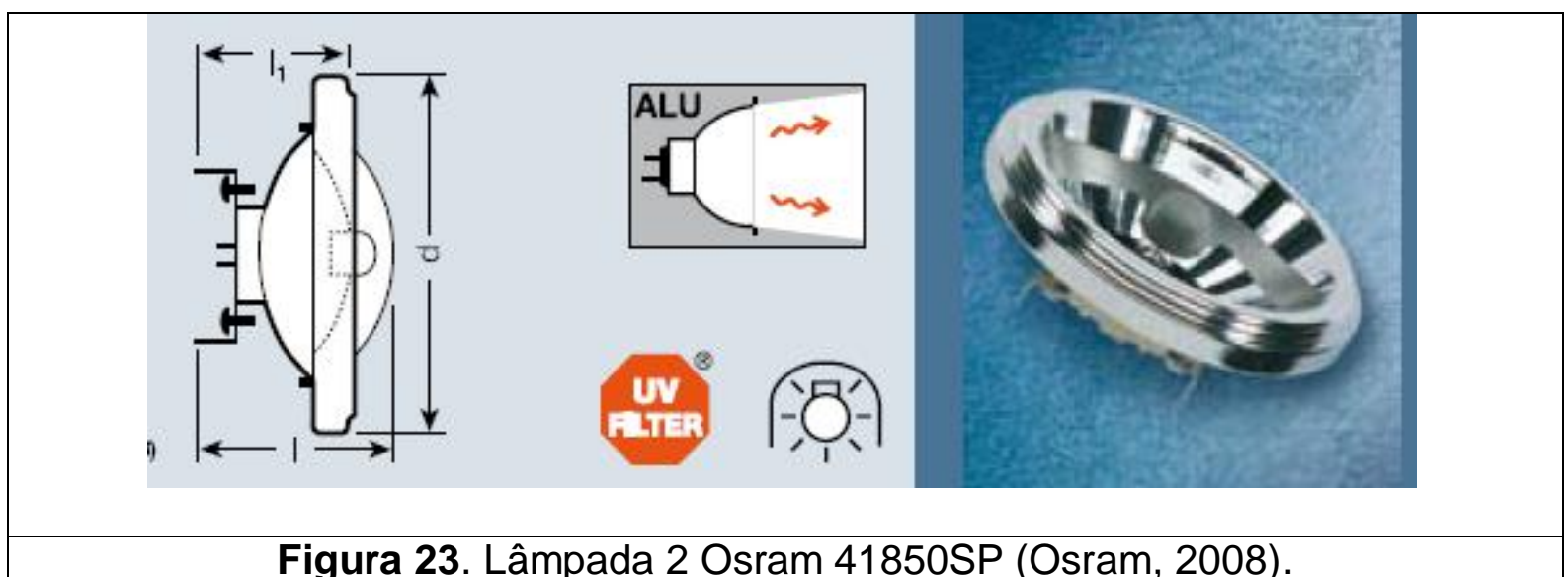

Figura 23. Lâmpada 2 Osram 41850SP (Osram, 2008).

2. Lente

Utilizamos uma lente geralmente usada em retroprojetores, da marca Essilor, que é feita de cristal e é do tipo convergente, possuindo $89 \pm 0,1 \mathrm{~mm}$ de diâmetro e foco de $120 \pm 0,1 \mathrm{~mm}$. O objetivo desta lente é concentrar o feixe luminoso emitido pela lâmpada sendo que seu foco foi posicionado dentro do filtro térmico, o que implicou na fixação do suporte da lente no centro do corpo principal.

\section{Corpo Principal}

Após seleção da lâmpada o corpo do HLS foi desenvolvido a partir de um tubo, de forma a adotar o formato cilíndrico, o que se justifica pela facilidade de alinhamento dos componentes do sistema.

O corpo principal foi desenvolvido a partir de um tubo de ferro que possui $127 \pm 0,1 \mathrm{~mm}$ de diâmetro, $135 \pm 0,1 \mathrm{~mm}$ de comprimento e $4 \pm 0,1 \mathrm{~mm}$ de espessura. $\mathrm{Na}$ parte superior do cilindro, foi feita uma abertura circular de raio $22 \pm 0,1 \mathrm{~mm}$, onde foi fixado um "cooler". 


\section{Filtro Térmico}

O filtro térmico é composto de um cilindro de alumínio oco com $53 \pm 0,5 \mathrm{~mm}$ de comprimento e $50 \pm 0,1 \mathrm{~mm}$ de diâmetro e $3 \pm 0,1 \mathrm{~mm}$ de espessura com duas janelas de vidro, com $50 \pm 0,1 \mathrm{~mm}$ de diâmetro e $2 \pm 0,1 \mathrm{~mm}$ de espessura que são fixadas as bases do cilindro por tampas de alumínio, sendo que cada uma possui de $56 \pm 0,1 \mathrm{~mm}$ diâmetro e $10 \pm 0,1 \mathrm{~mm}$ de espessura. Estas tampas são rosqueadas ao cilindro pressionando o vidro a um anel de borracha que está embutido na parede no cilindro.

Este cilindro foi preenchido por água conforme justificado nas seções $5.2 \mathrm{e}$ 5.3 deste trabalho, ou seja, a água foi escolhida para filtrar parte do espectro infravermelho presente na emissão da lâmpada e que é desnecessário e pode causar aquecimento e até queimaduras da região a ser irradiada.

Prevendo um aumento excessivo da água no interior do filtro, visto que a temperatura no ponto focal da lâmpada atingiu $130^{\circ} \mathrm{C}$ foram instalados, na lateral do cilindro, conectores para mangueiras. Estas foram conectadas a um recipiente de acrílico com a capacidade para armazenar 1,5 litros de água, onde está presente um a bomba submersa (Sarlo-SB160V) com capacidade de 120I/h que é responsável pela circulação de água no interior do filtro.

\section{Cooler}


Com o objetivo de tornar a dissipação de calor emitida pela lâmpada mais efetiva e prevenir um aquecimento desnecessário do corpo do equipamento e dos demais componentes foi introduzido um "cooler" (marca Omega), que funciona como exaustor expulsando o ar quente para fora do equipamento. Este "cooler" funciona em $12 \mathrm{~V}$, com $0,07 \mathrm{~W}$ de potência e tem as seguintes dimensões $50 \pm 0,1 \mathrm{~mm}$ de largura, $50 \pm 0,1 \mathrm{~mm}$ de comprimento e $10 \pm 0,1 \mathrm{~mm}$ de espessura.

\section{Suportes}

Os suportes para a lente e para a lâmpada foram feitos em alumínio sob medida de modo a garantir a durabilidade e um prefeito encaixe dos componentes do equipamento.

O suporte para a lente é um anel de alumínio maciço que possui um "rebaixo" de modo que lente, encoste na parte interna do suporte e um anel de latão fixa a lente no suporte de alumínio por pressão o anel de alumínio possui $115 \pm 0,1 \mathrm{~mm}$ de diâmetro externo, $88 \pm 0,1 \mathrm{~mm}$ de diâmetro interno a $13 \pm 0,1 \mathrm{~mm}$ de espessura (no encaixe da lente), $83 \pm 0,1 \mathrm{~mm}$ de diâmetro interno a $12 \pm 0,1 \mathrm{~mm}$ de espessura (no restante) e $25 \pm 0,1 \mathrm{~mm}$ de espessura total. Este anel foi fixado no centro do corpo principal.

A lâmpada é fixada no corpo principal através de travas móveis. Para um perfeito encaixe da lâmpada foi soldado ao corpo um anel ferro que faz com que a lâmpada encaixe perfeitamente no corpo, mantendo seu alinhamento.

Por fim temos o suporte do filtro térmico que funciona como base anterior do corpo principal, fixada a este e ao filtro térmico por parafusos. Possui $125 \pm 0,1 \mathrm{~mm}$ 
de diâmetro externo e $4 \pm 0,1 \mathrm{~mm}$ de espessura total, $118 \pm 0,1 \mathrm{~mm}$ de diâmetro interno a $1 \pm 0,1 \mathrm{~mm}$ de espessura (no encaixe com o corpo principal).

\section{Sistema Elétrico}

As conexões elétricas da lâmpada e do "cooler" foram protegidas por uma capa metálica cilíndrica, de alumínio e fixada ao refletor da lâmpada através de um anel de pressão a fim de evitar choques elétricos. Um cabo do tipo "PP", de 2,5mm de diâmetro, faz a conexão entre a lâmpada e a fonte de alimentação que foi desenvolvida pelo próprio fabricante da lâmpada (OSRAM modelo "Halotronic HTM105).

Devido às características da fonte o equipamento só opera em 220Volts.

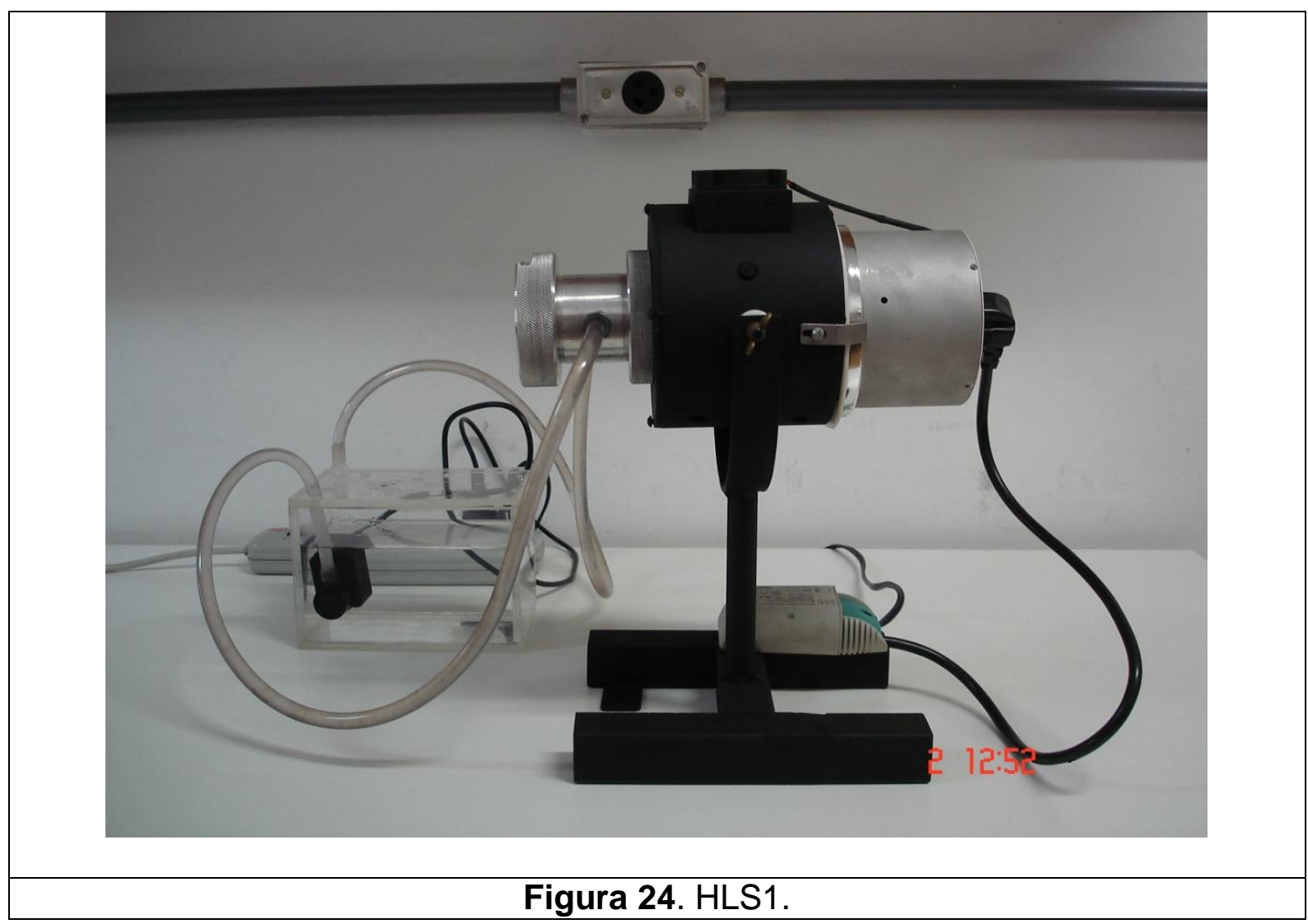




\subsubsection{Resultados dos Testes do HLS 1}

\subsubsection{Resultados de Irradiância}

A seguir estão representadas as medidas de irradiância do HLS1 onde o ponto zero da distância longitudinal corresponde à mínima distância possível entre o detector e o filtro térmico.

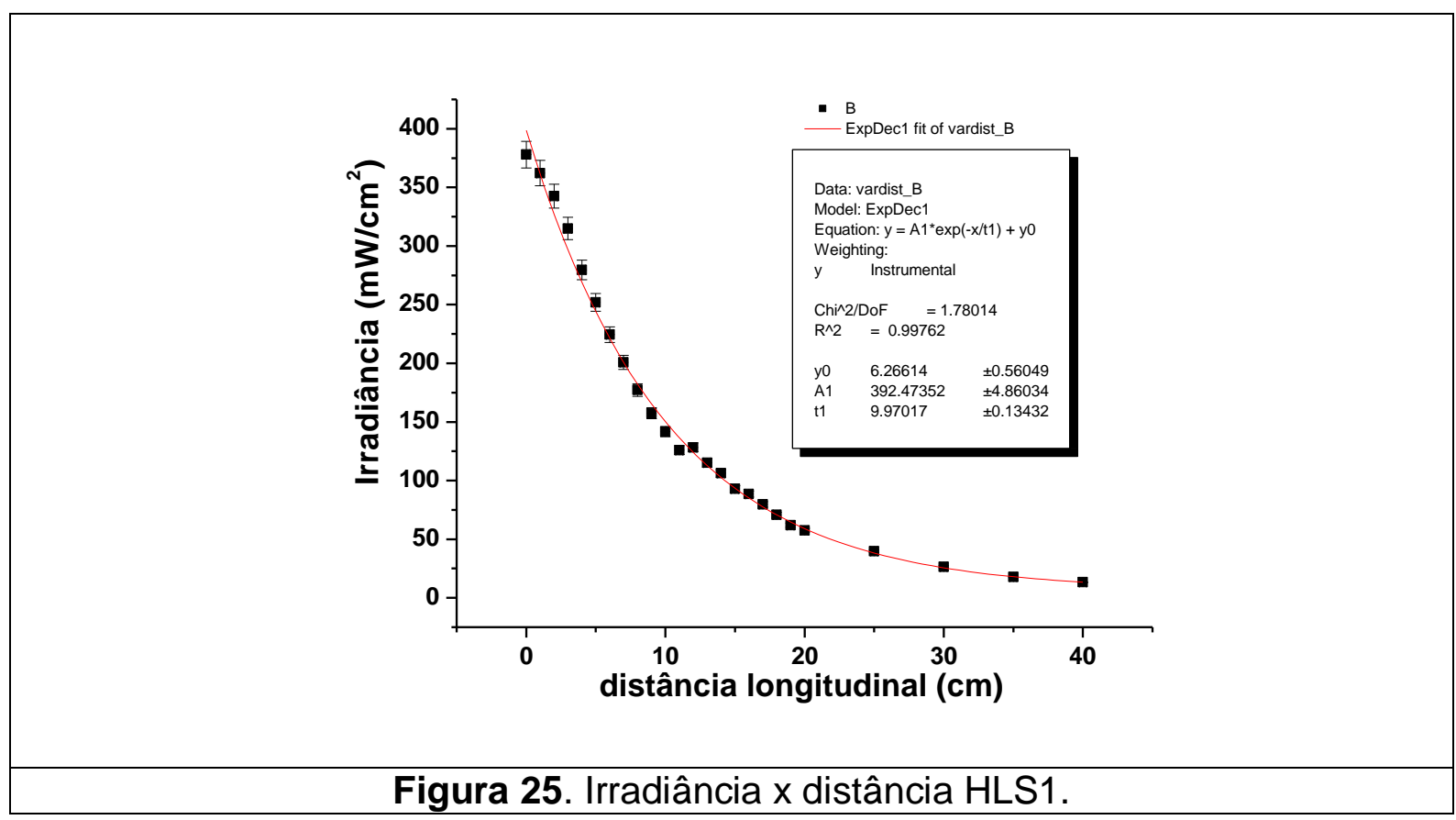

Abaixo estão as medidas da irradiância desta lâmpada no eixo axial, como detector posicionado a 5 e a $15 \mathrm{~cm}$ da fonte na posição inicial. 


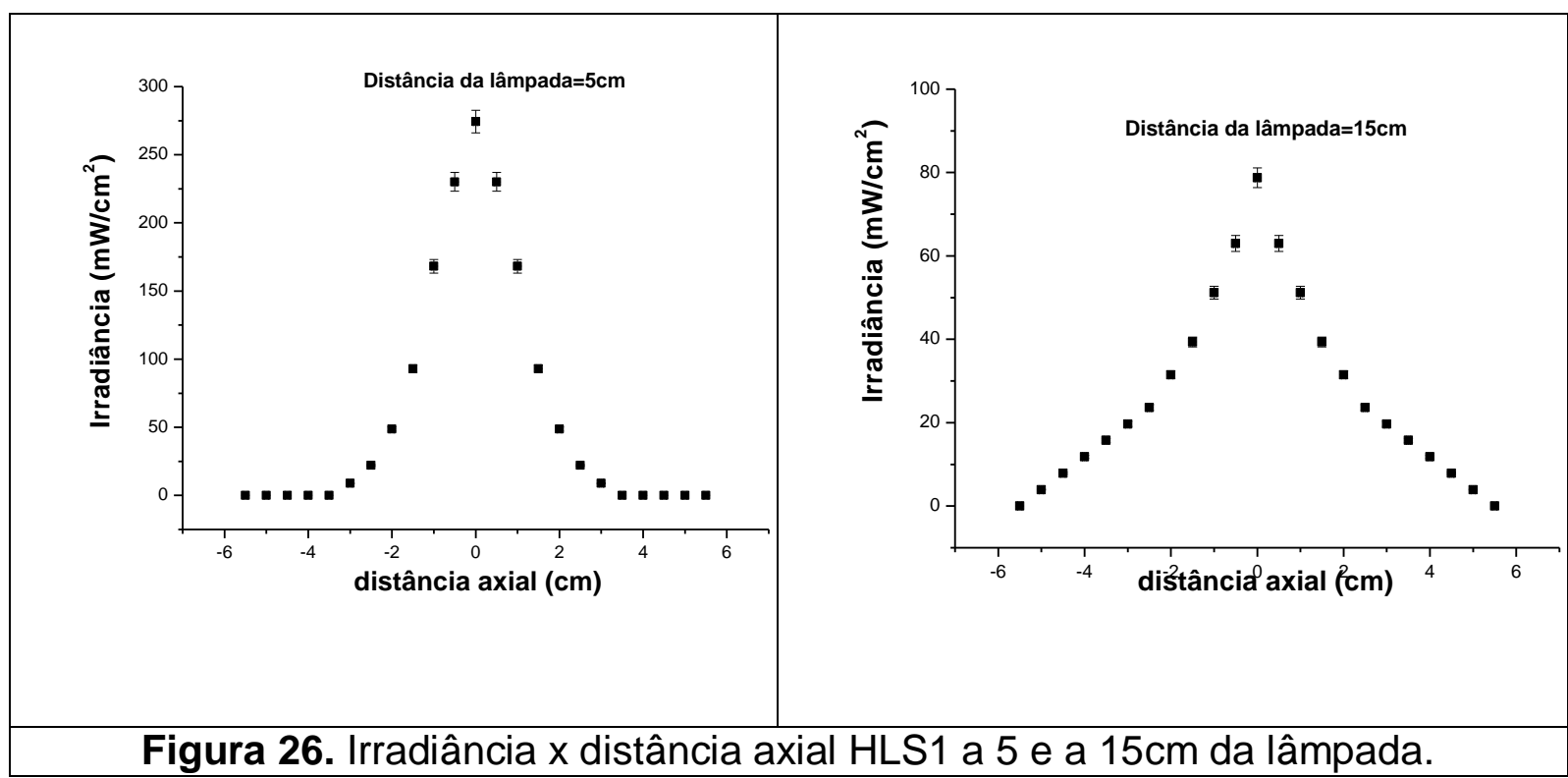

Como podemos observar após a construção do protótipo os dados de irradiância sofreram uma redução se compararmos com os dados medidos na lâmpada 2 (Figura 19), este fato é devido a presença do filtro térmico, que retirou parte do espectro infravermelho diminuindo, portanto a irradiância total, no entanto estes valores ainda são suficientes para aplicações em fotobiologia e fotomedicina.

\subsubsection{Resultados de Temperatura.}

\subsection{Temperatura do corpo}

Utilizando o termômetro (Minipa-MT511) podemos observar a variação da temperatura no corpo do equipamento. 


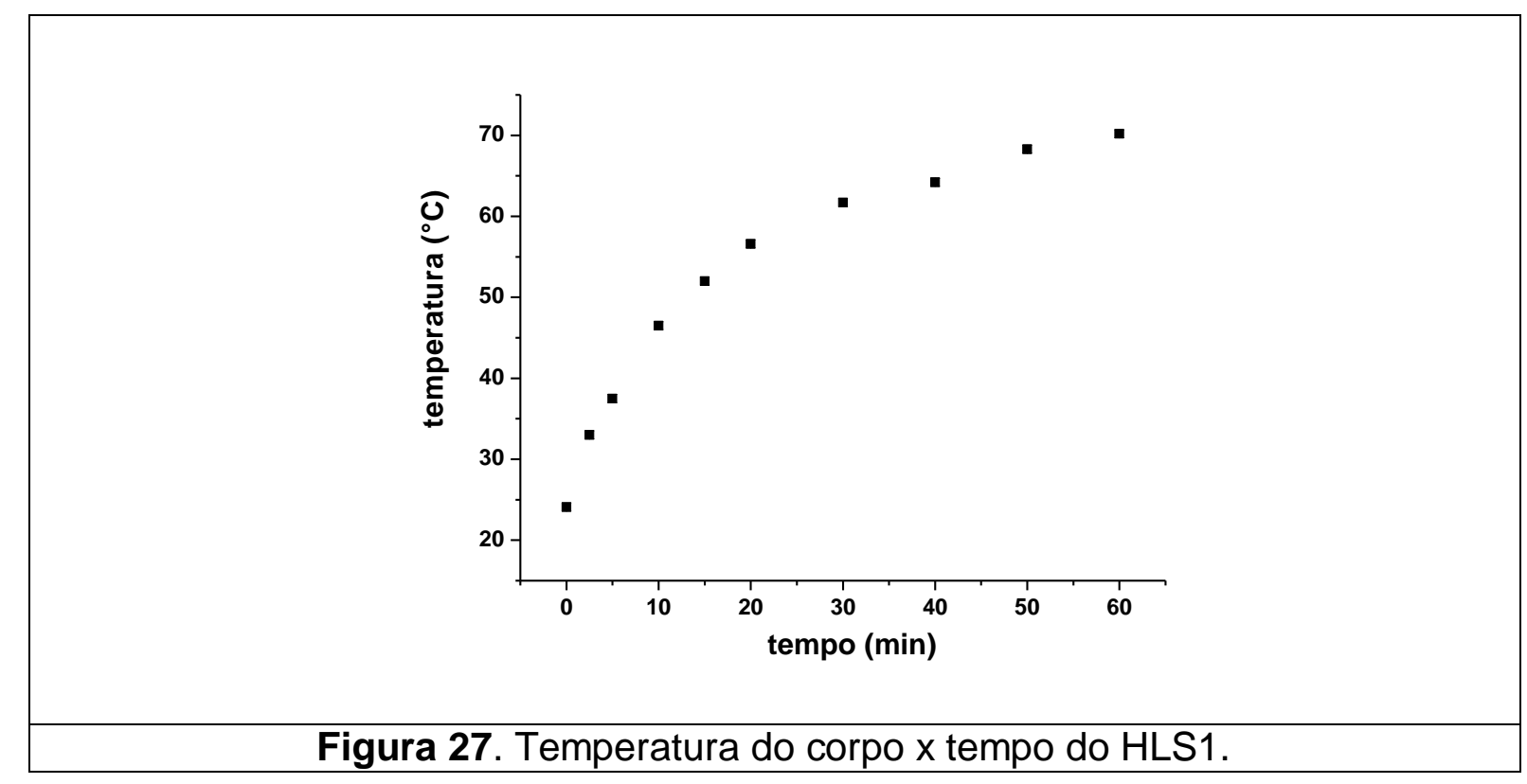

Podemos notar que essa temperatura está acima do aceitável, pois poderá causar queimaduras em quem estiver manuseando o equipamento.

\subsection{Temperatura do sistema de filtro térmico}

Com relação à temperatura da água no filtro podemos dizer que ela ficou estável em aproximadamente $28 \pm 1^{\circ} \mathrm{C}$ após 90 minutos de funcionamento do HLS1. Esta temperatura foi medida com um termômetro de mercúrio em contato direto com a água do recipiente de troca.

\subsection{Temperatura na saída do filtro térmico}

Com relação à temperatura na saída do filtro podemos dizer que o filtro funcionou como era esperado reduzindo a temperatura de $130 \pm 1^{\circ} \mathrm{C}$ medida no ponto focal graus para $38 \pm 1^{\circ} \mathrm{C}$, medido na saída do filtro. Este valor é aceitável 
para tratamento em fotomedicina, pois esta dentro da faixa da temperatura viável do corpo humano.

\subsubsection{Avaliação Estrutural do HLS1}

Após avaliação dos componentes do protótipo HLS1 notamos algumas deficiências que devem ser resolvidas.

1. O sistema de fixação da lâmpada no corpo do equipamento é frágil, de difícil montagem e não garante o reposicionamento correto da lâmpada em caso de substituição.

2. O sistema de proteção das conexões elétricas da lâmpada e da fonte de alimentação é frágil e de difícil montagem podendo provocar curto circuito se não for fixado corretamente à lâmpada.

3. O suporte para o cooler foi de difícil construção, sendo necessárias horas de trabalho, o que inviabiliza uma produção em grande escala do produto.

4. O sistema de suporte pivotante do equipamento se mostrou na prática ineficiente, pois, o modo de operação era sempre na horizontal ou vertical, não sendo necessárias angulações diferentes para o posicionamento do equipamento.

5. De acordo com as medidas de temperatura do corpo, o cooler não cumpriu seu papel de auxílio no resfriamento de forma satisfatória. Portanto deve estar subdimensionado e deve ser substituído.

6. Como mencionado anteriormente o corpo do equipamento, não oferece boa dissipação de calor. 
Tomando por base as considerações acima resolvemos construir um novo protótipo com a substituição do corpo principal por um que oferecesse melhor dissipação de calor.

Os demais componentes que funcionaram a contento no HLS1 foram reutilizados e adaptados no HLS2.

\subsection{Construção do Protótipo HLS2}

\subsubsection{Elementos de construção.}

O HLS2 foi construído, tomando por base os sucessos e fracassos do HLS1, sendo que somente os sistemas que apresentaram deficiência foram substituídos, e estão descritos abaixo.

\section{Corpo Principal}

O corpo principal do HLS1 foi substituído por um corpo produzido industrialmente que apresentou melhor dissipação do calor de modo a não causar queimaduras.

A princípio surgiu à idéia de adicionarmos haletas ao corpo, pois ao aumentar a superfície de troca de calor teríamos por conseqüência uma melhor dissipação do mesmo.

$\mathrm{Na}$ teoria deveria funcionar, mas na prática a execução desta idéia era inviável pelo mesmo motivo do suporte do cooler do HLS1, seria um trabalho de difícil execução, e que inviabilizaria a produção do equipamento. 
Para adequar um corpo as nossas necessidades seria então necessário a execução de um projeto técnico, com a posterior execução de um molde para fundição da peça.

Novamente era um processo inviável, mas desta vez por motivos econômicos, pois não tínhamos verba suficiente para executar esta etapa, além do fato de estarmos desenvolvendo um protótipo que pode sofrer alterações até sua versão final.

A solução encontrada para este problema foi à utilização de um corpo disponível no mercado, que atendesse nossas necessidades, assim após pesquisa chegamos à conclusão que o corpo utilizado geralmente em motores elétricos atendia nossas necessidades, pois ele possuía: as características necessárias para dissipação de calor, abertura lateral que poderia ser utilizada para o cooler e ainda a possibilidade de se adaptar as próprias proteções deste tipo de corpo no sistema elétrico.

Após pesquisa determinamos qual modelo de corpo se adaptava melhor as nossas necessidades. Foi escolhida a carcaça 80-IP55 de um motor elétrico produzida pela empresa WEG. O desenho técnico esta mostrado abaixo. 


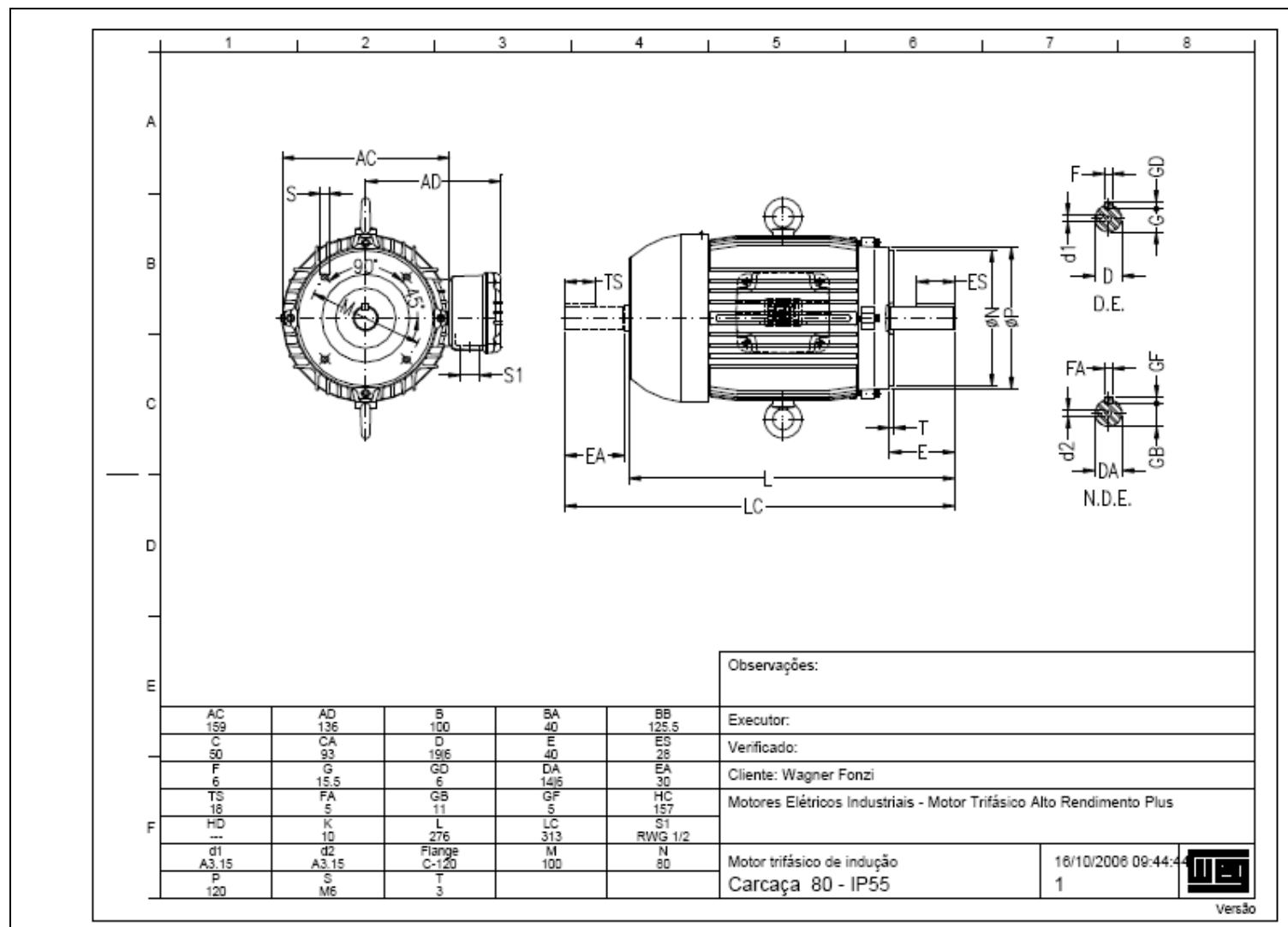

Figura 28. Desenho técnico do corpo do HLS2.

Determinadas as características do corpo foram feitas as adaptações necessárias neste para que os demais componentes fossem acoplados.

\section{Cooler}

Com o objetivo de tornar essa dissipação de calor ainda mais efetiva foi instalado no HLS2 um cooler maior e mais potente que seu antecessor. Este "cooler" (marca Colorful), funciona também em 12V, mas tem 0,23W de potência, ou seja ele é cerca de três vezes mais potente que seu antecessor e possui as seguintes dimensões $75 \pm 0,1 \mathrm{~mm}$ de largura, $75 \pm 0,1 \mathrm{~mm}$ de comprimento e $25 \pm 0,1 \mathrm{~mm}$ de espessura. 


\section{Suportes}

Devido à substituição do corpo principal foi necessária a construção de um novo suporte para lente.

Do mesmo modo que o anterior este suporte para a lente é uma anel de alumínio maciço que possui um "rebaixo" de modo que lente encoste na parte interna do suporte e um anel de latão fixa a lente no suporte de alumínio por pressão o anel de alumínio possui $130 \pm 0,1 \mathrm{~mm}$ de diâmetro externo, $88 \pm 0,1 \mathrm{~mm}$ de diâmetro interno e $13 \pm 0,1 \mathrm{~mm}$ de espessura no encaixe da lente, no restante ele possui $83 \pm 0,1 \mathrm{~mm}$ de diâmetro interno e $12 \pm 0,1 \mathrm{~mm}$ de espessura, totalizando e $25 \pm 0,1 \mathrm{~mm}$ de espessura total. Este anel está fixado no centro do corpo principal através de parafusos.

Da mesma forma que o suporte da lente o suporte para a lâmpada foi feito na forma de um anel de alumínio maciço que possui um "rebaixo" de modo que lâmpada encoste, na parte interna do suporte e esta é fixada ao suporte por três parafusos de encosto fixados na lateral externa do anel, este suporte é fixado ao corpo principal e funciona com base deste cilindro, este suporte possui ainda um rebaixo externo onde é fixada uma capa metálica que protege as conexões elétricas da lâmpada. $O$ anel possui $157 \pm 0,1 \mathrm{~mm}$ de diâmetro externo, $132 \pm 0,1 \mathrm{~mm}$ de diâmetro interno a $5 \pm 0,1 \mathrm{~mm}$ de espessura no encaixe com o corpo principal, no encaixe da lâmpada ele possui $111 \pm 0,1 \mathrm{~mm}$ de diâmetro interno a $9 \pm 0,1 \mathrm{~mm}$ de espessura totalizando $16 \pm 0,1 \mathrm{~mm}$ de espessura, com rebaixo de $1 \pm 0,1 \mathrm{~mm}$ para 0 
encaixe da capa de ferro. Este anel está fixado na base posterior do corpo principal por meio de parafusos.

\section{Sistema Elétrico}

As conexões elétricas da lâmpada e do "cooler" foram protegidas por uma capa metálica acoplada ao suporte da lâmpada a fim de evitar choques elétricos. Um cabo do tipo "PP", de 2,5mm de diâmetro, faz a conexão entre a lâmpada e a fonte de alimentação (Osram modelo "Halotronic HTM105"), que é conectado a rede por meio de outro cabo "PP" de 2,5mm de diâmetro.

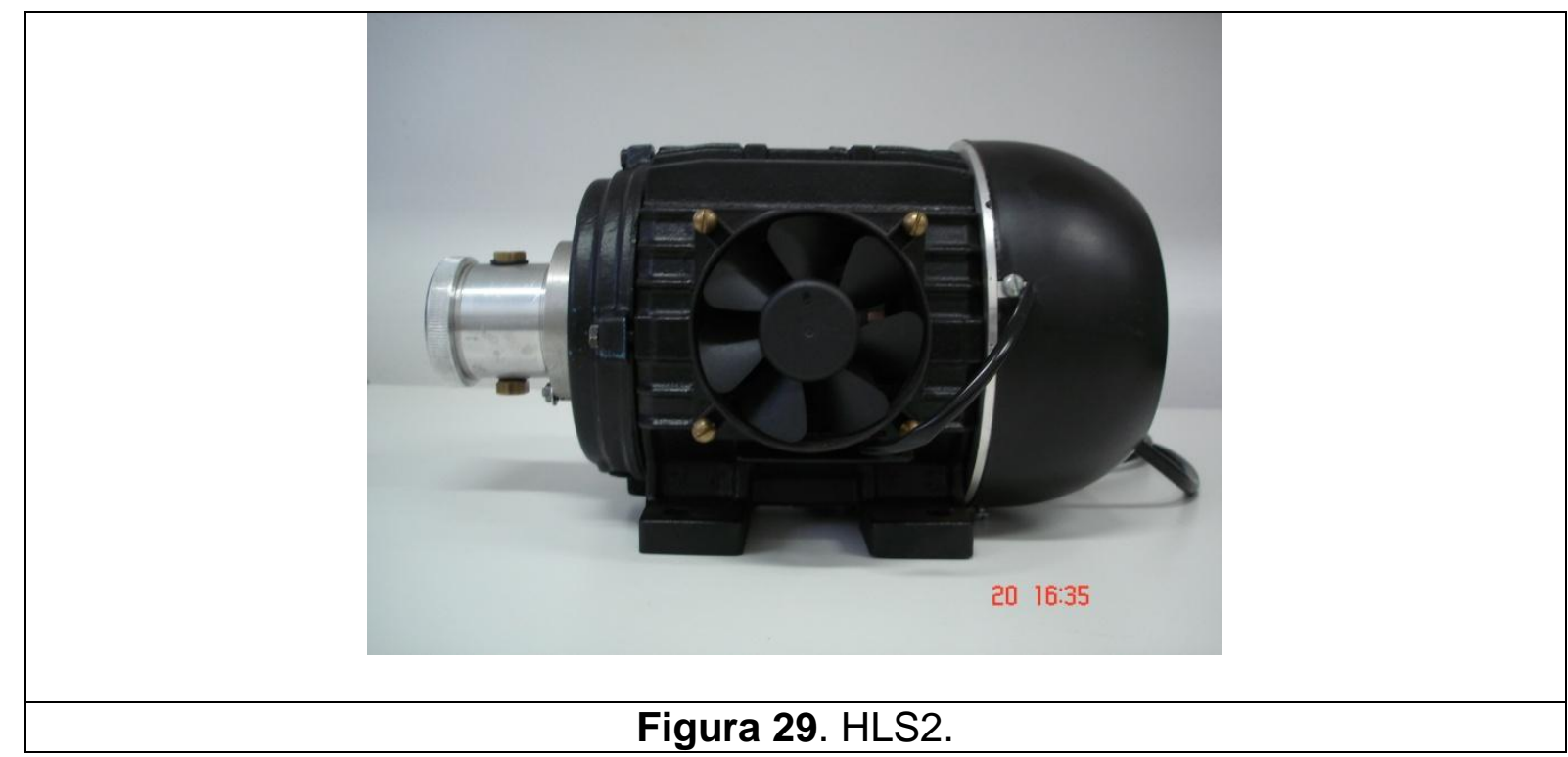

\subsubsection{Determinação do esquema ótico}

Devido a mudanças no corpo do equipamento o esquema ótico sofreu pequenas mudanças no posicionamento dos componentes, como podemos observar na figura abaixo. 


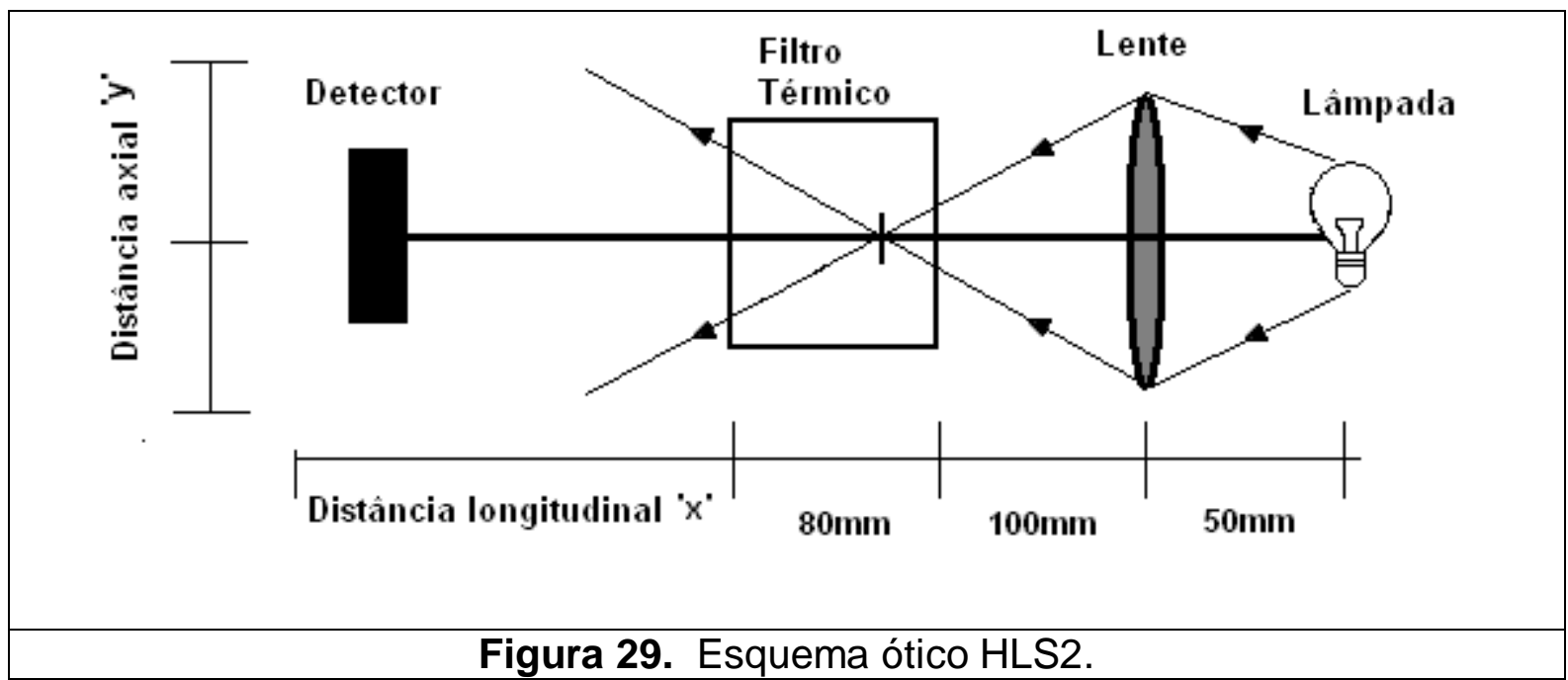

De fato a única alteração que foi feita do esquema ótico do HLS1 para o esquema do HLS2 foi o aumento na distância entre a lente e o filtro térmico, devido à substituição do corpo do equipamento, este aumento na distância está de acordo com previsão geométrica.

\subsubsection{Resultados dos Testes do HLS 2}

\subsubsection{Resultados de Irradiância}

Os resultados das medidas de irradiância do HLS2 estão mostrados abaixo. 


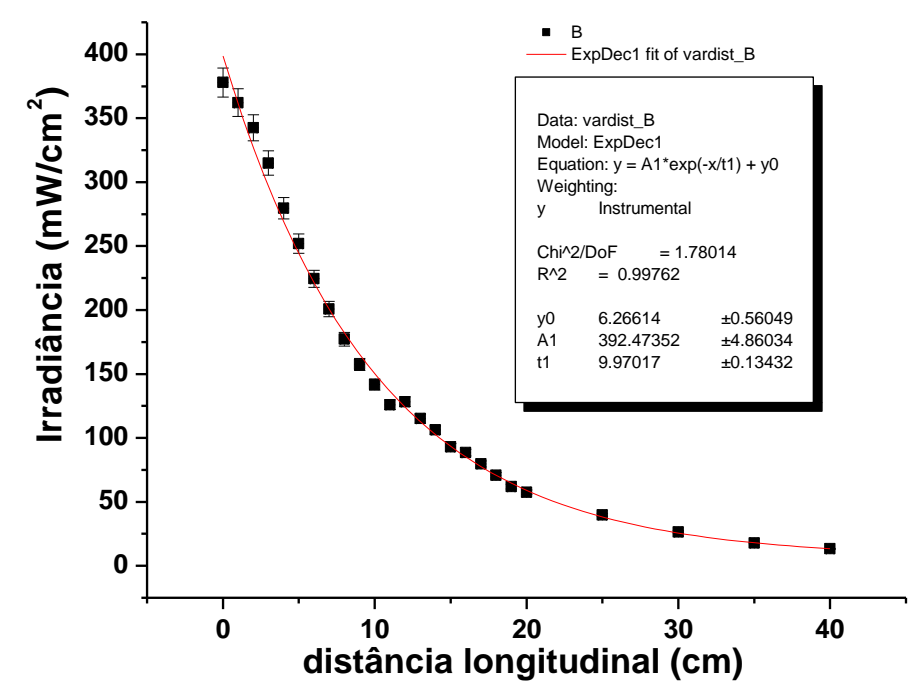

Figura 31. Irradiância x distância HLS2.

Abaixo estão as medidas da irradiância desta lâmpada no eixo axial, como detector posicionado a 5 e a $15 \mathrm{~cm}$ da fonte na posição inicial.

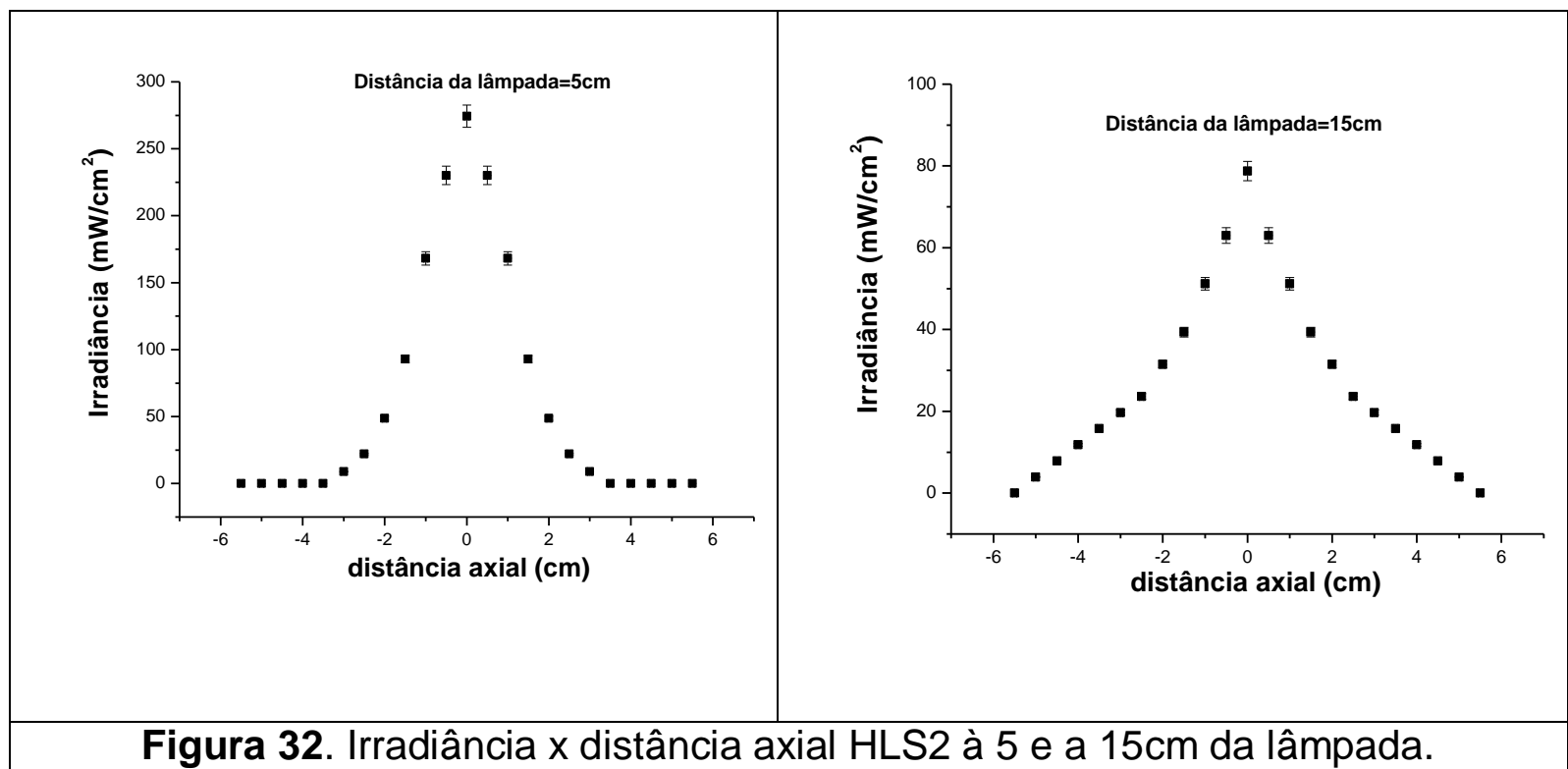


Como podemos observar após a construção do HLS2 os dados de irradiância, não sofreram significativas alterações e nem deveriam, pois as limitações geométricas e os principais componentes do HLS1 foram mantidos.

\subsubsection{Resultados de Temperatura.}

\subsection{Temperatura do corpo}

Utilizando novamente o termômetro (Minipa MT511), podemos observar a variação da temperatura no corpo do equipamento.

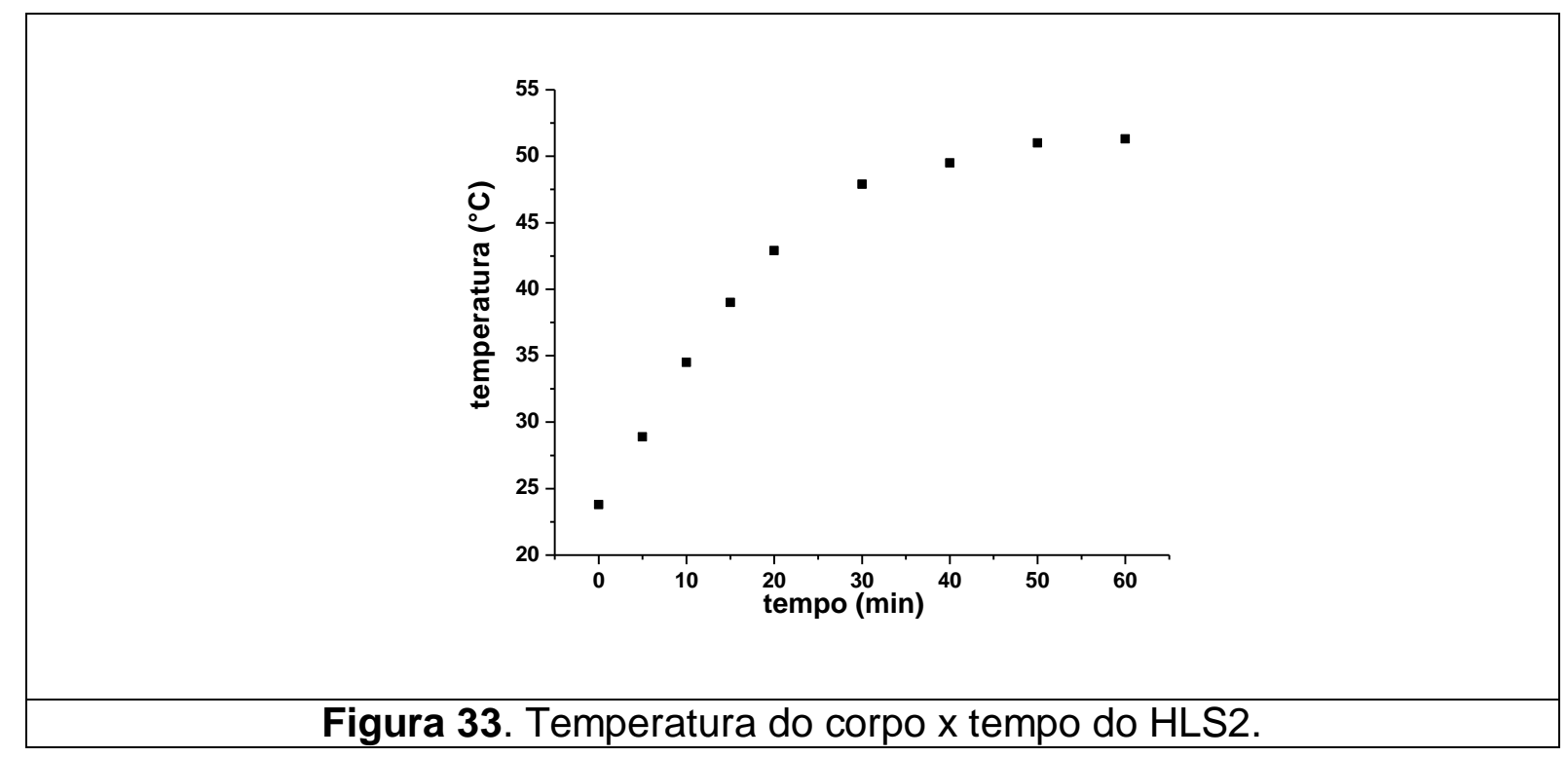

Podemos notar que essa temperatura apresenta valores compatíveis com o manuseio do equipamento, significando, portanto que uma maior área de contato provocou uma melhor dissipação de calor resolvendo o problema de aquecimento excessivo do corpo do equipamento. Devemos ainda ressaltar que embora não tenhamos quantificado, a substituição por um cooler de maior potência pode ter contribuído para este decréscimo da temperatura do corpo. 


\subsection{Temperatura do sistema de filtro térmico}

Durante os testes deste protótipo resolvemos testar a eficácia do sistema de filtro térmico.

Para efetuar este procedimento desconectamos as mangueiras que faziam a troca da água do filtro térmico. A seguir vedamos uma saída e introduzimos um termômetro de mercúrio na outra, utilizando uma borracha para garantir a vedação.

Monitoramos então a temperatura de acordo com o gráfico abaixo

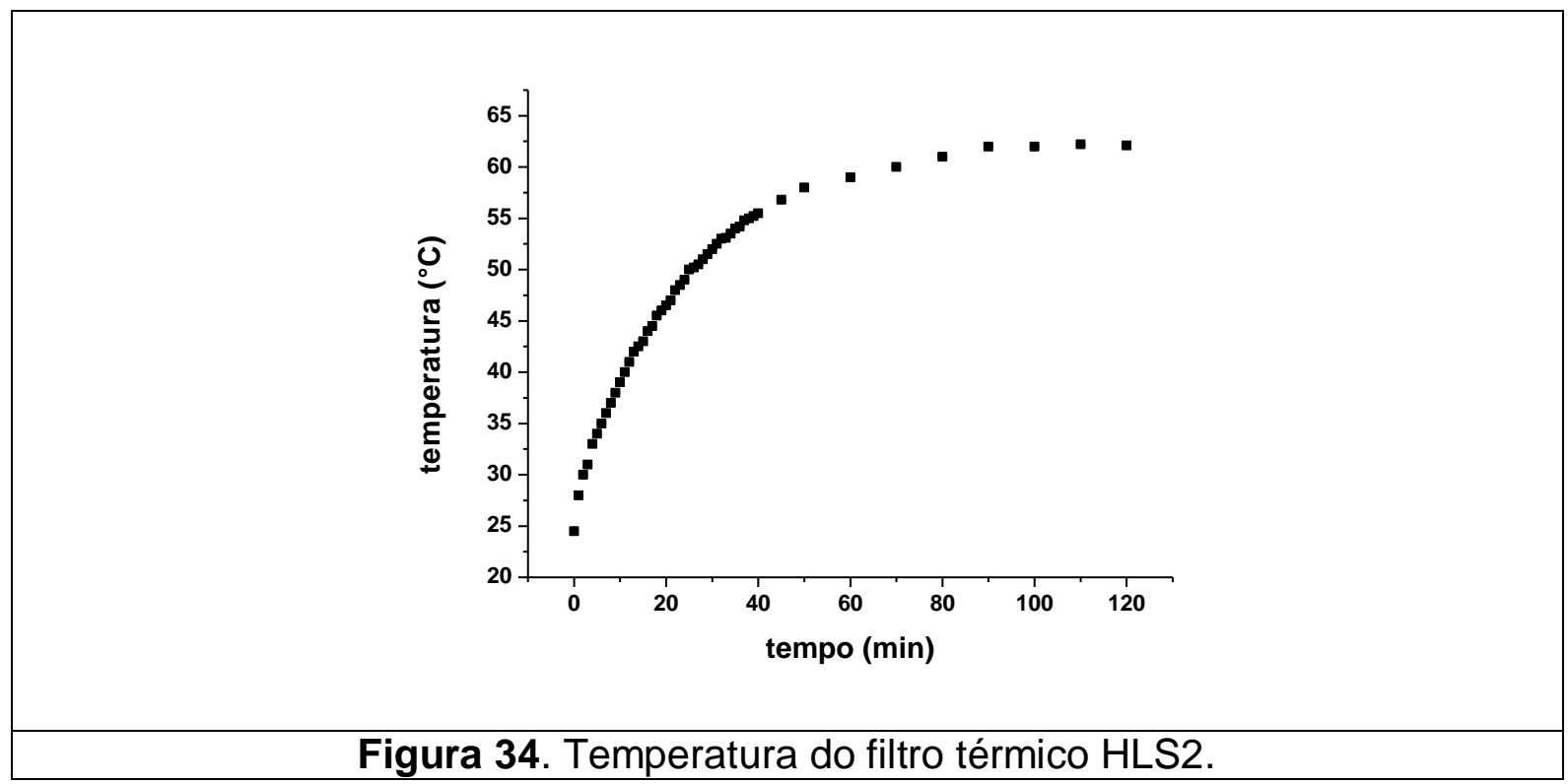

Como podemos notar no gráfico a temperatura estabilizou em aproximadamente $62 \pm 1^{\circ} \mathrm{C}$, valor este que dispensa o sistema de troca de água, pois quando projetamos o sistema acreditávamos que a água alcançaria valores maiores de temperatura, fato que não foi comprovado. 
Deste modo os demais testes deste equipamento, foram realizados com o filtro térmico isolado, ou seja, preenchido por água, mas sem o sistema de troca.

\subsection{Temperatura na saída do filtro térmico}

Com relação à temperatura na saída do filtro podemos dizer que não houve alteração significativa entre o sistema com resfriamento $38 \pm 1^{\circ} \mathrm{C}$ e sem resfriamento $39 \pm 1^{\circ} \mathrm{C}$, o que nos fornece mais uma comprovação que o sistema de resfriamento pode ser removido do protótipo sem prejuízo ao resultado final.

\subsubsection{Avaliação Estrutural do HLS2}

Após avaliação dos componentes notamos que apesar de satisfazer boa parte das nossas exigências ele apresentava um novo problema.

Este problema está relacionado ao peso do equipamento, que atingiu 5,3kg valor que dificulta a mobilidade do equipamento, o que poderia se tornar um entrave a sua utilização.

Para solucionar este problema resolvemos que deveríamos elaborar um novo protótipo onde resolveríamos este problema e faríamos novas modificações. 


\subsection{Construção do Protótipo HLS3}

\subsubsection{Elementos de construção}

\section{Corpo Principal}

O corpo principal do HLS2 foi substituído por uma corpo de alumínio da marca Eberle, que além de tornar o protótipo mais leve $(3,2 \mathrm{~kg})$ apresenta melhor características de dissipação de calor do anterior.

Desde a substituição do corpo no HLS2 surgiu à idéia de utilizarmos o corpo em alumínio, pois alguns modelos de motor elétrico são fornecidos com este tipo de corpo, no entanto, geralmente este corpo não é vendido separadamente, pois não está sujeito a corrosão como de ferro fundido.

Após longa pesquisa entre os fabricantes de motores encontramos um que fornecia o corpo em alumínio.

Após pesquisa determinamos qual modelo de corpo se adaptava melhor as nossas necessidades. $O$ desenho técnico esta mostrado abaixo. 

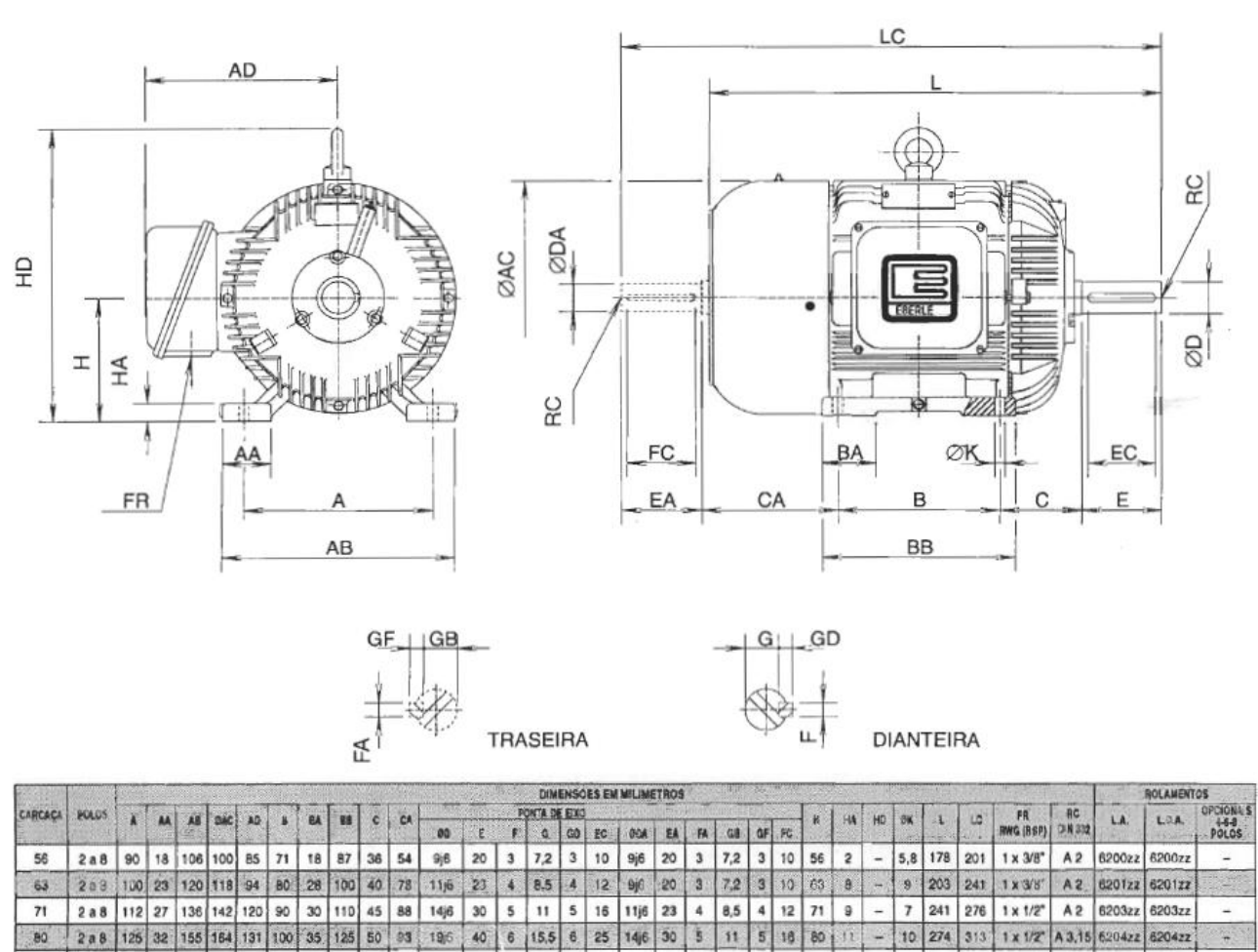

Figura 35. Desenho técnico do corpo do HLS3.

Determinadas as características do corpo foram feitas as adaptações necessárias neste para que os demais componentes fossem acoplados.

\section{Filtro Térmico}

Com a finalidade de eliminar as saídas de água construímos um novo filtro térmico em alumínio. As dimensões deste filtro que sofreram alterações com relação ao antecessor são: as bases que passam a ter $10 \pm 0,5$ e $20 \pm 0,5 \mathrm{~mm}$ de espessura, onde a base de $20 \pm 0,5 \mathrm{~mm}$ foi especialmente trabalhada de forma a servir de suporte para filtros de cores de $50 \times 50 \pm 0,5 \mathrm{~mm}$ e. As demais dimensões foram mantidas. 
3. Cooler

Como a abertura lateral no corpo do HLS3 era menor que a do HLS2 substituímos o "cooler" por um que se adéqua se a esta abertura. Este "cooler" é da marca Omega e funciona também em 12V, e possui a mesma potência que seu antecessor $(0,23 \mathrm{~W})$ e possui as seguintes dimensões $70 \mathrm{~mm}$ de largura, $70 \mathrm{~mm}$ de comprimento e $15 \mathrm{~mm}$ de espessura.

\section{Suportes}

Foi construído também em alumínio o suporte do filtro térmico que funciona como base anterior do corpo principal. Ele possui as seguintes dimensões: $135 \pm 0,5 \mathrm{~mm}$ de diâmetro externo e $15 \pm 0,5 \mathrm{~mm}$ de espessura total, $129 \pm 0,5 \mathrm{~mm}$ de diâmetro interno a $7 \pm 0,5 \mathrm{~mm}$ de espessura (no encaixe com o corpo principal).

\section{Sistema Elétrico}

Devido à possibilidade de se utilizar o HLS tanto no suporte, como fora dele, foi desenvolvida uma caixa de controle que abriga o transformador,que possui chave interruptora com led de advertência e "dimmer". 


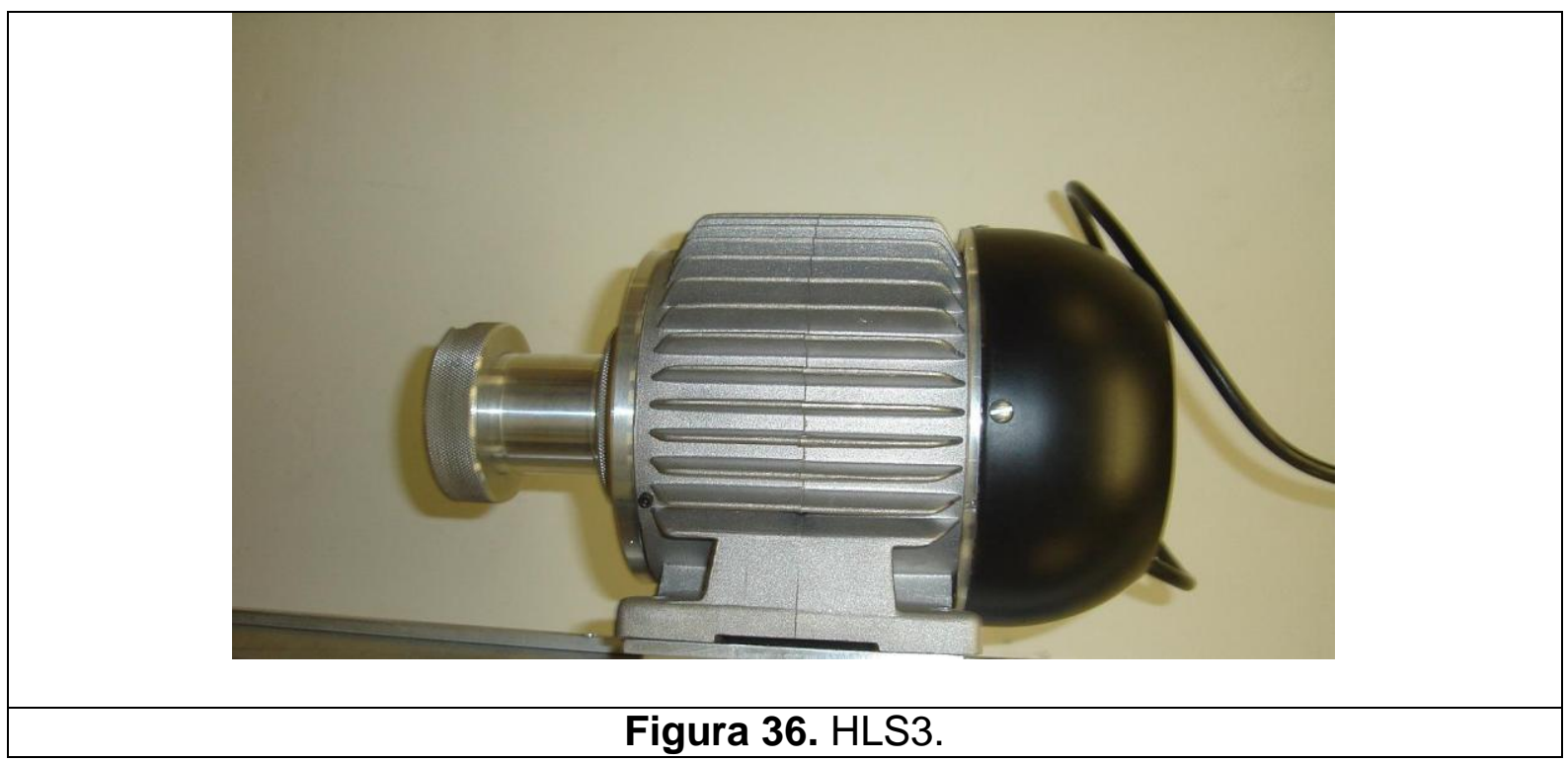

\subsubsection{Determinação do esquema ótico}

Após determinar as características do corpo foram feitas as adaptações necessárias neste para que os demais componentes fossem acoplados.

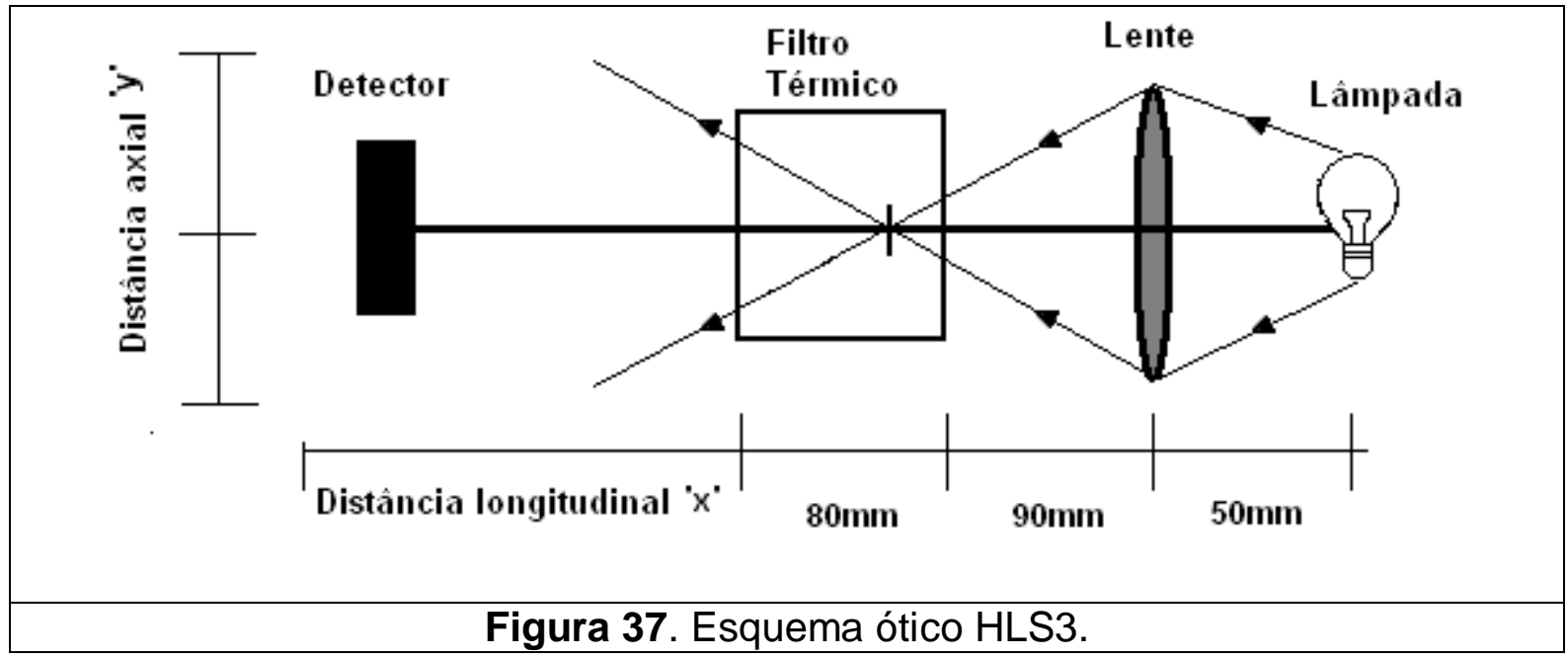


Neste protótipo foram incorporadas modificações relacionadas com a versatilidade de aplicação do equipamento, que seriam: a possibilidade de utilizar filtros ópticos na saída do filtro térmico de modo a selecionar a região espectral de interesse e do desenvolvimento de um sistema de suporte vertical que facilitaria a utilização do equipamento no laboratório.

As alterações do esquema ótico do HLS2 para o esquema do HLS3 foram: a possibilidade de utilização de filtros de cores, que não influíram no tamanho do filtro térmico, pois o suporte para os filtros foi incorporado ao filtro térmico e à diminuição na distância entre a lente e o filtro térmico, devido à substituição do corpo do equipamento. Este esquema ótico possui as mesmas dimensões do esquema do HLS1 e está dentro das previsões geométricas.

\subsubsection{Resultados dos Testes do HLS3}

\subsubsection{Resultados de Irradiância}

Os resultados das medidas de irradiância do HLS3 estão mostrados abaixo. 


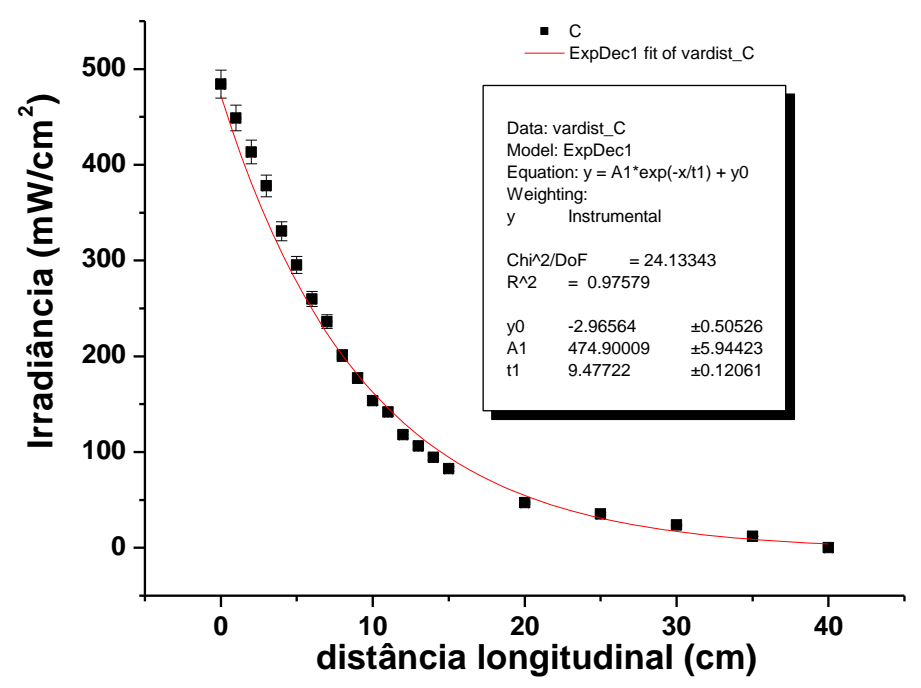

Figura 38. Irradiância x distância HLS3.

Abaixo estão as medidas da irradiância desta lâmpada no eixo axial, como detector posicionado a 5 e a $15 \mathrm{~cm}$ da fonte na posição inicial.

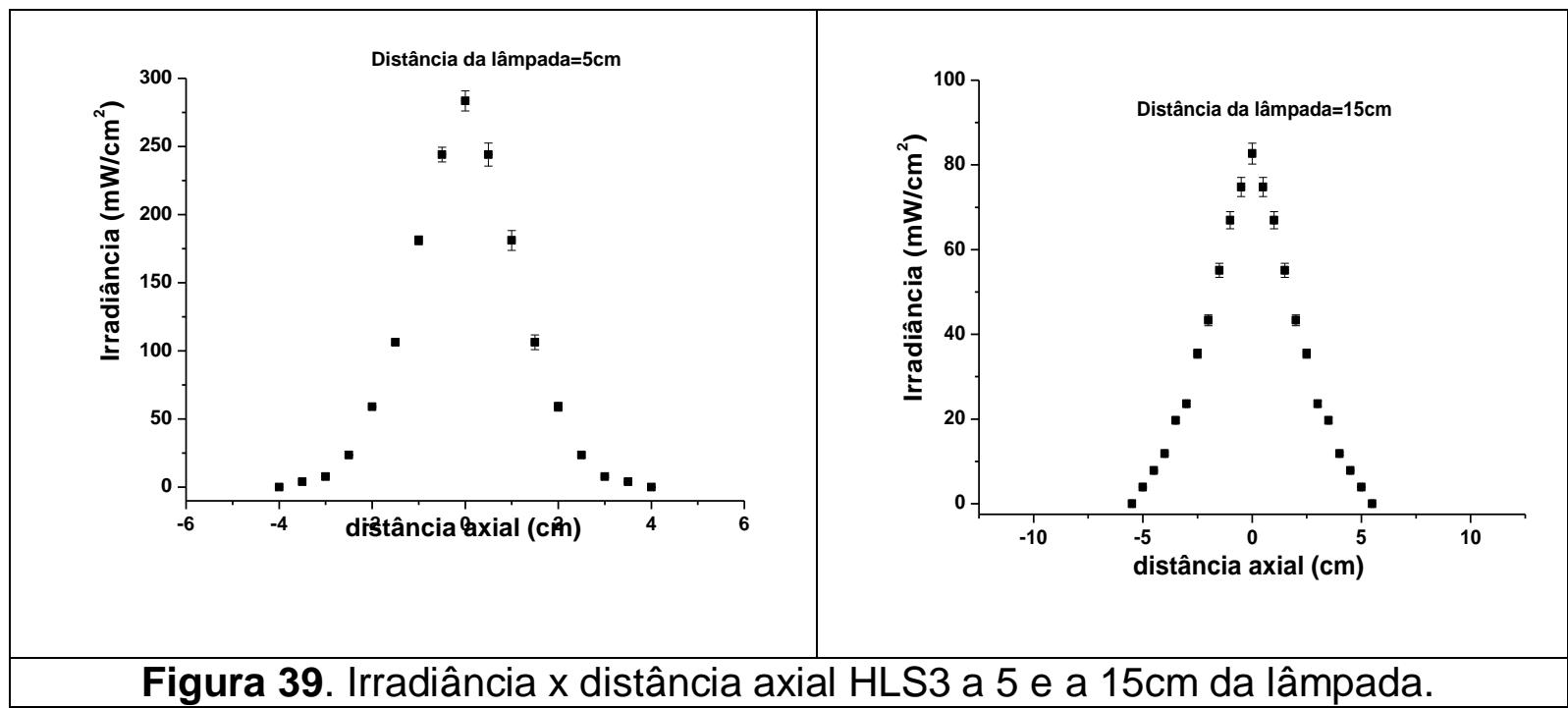

Novamente podemos observar após a construção do HLS3 os dados de irradiância, não sofreram significativas alterações e nem deveriam, pois as 
limitações geométricas foram respeitadas e os principais componentes do HLS2 foram mantidos.

\subsubsection{Resultados de Temperatura.}

\subsection{Temperatura do corpo}

Estes testes foram realizados com o propósito de verificar se a mudança do corpo equipamento causou alterações na temperatura externa deste.

Utilizando novamente o termômetro (Minipa MT511), podemos observar a variação da temperatura no corpo do equipamento.

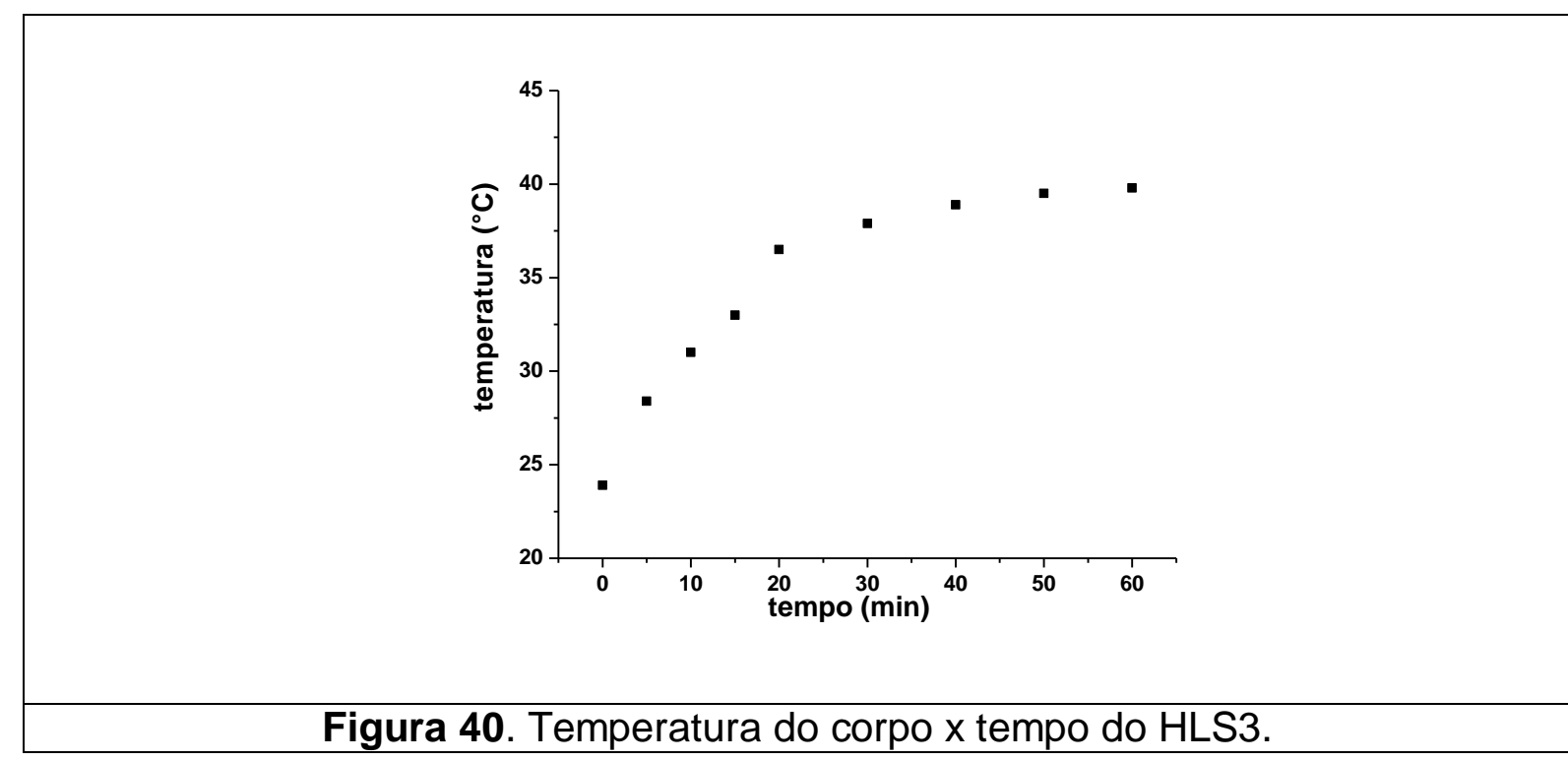

Podemos notar que essa temperatura sofreu significativas alterações (diminuição de cerca de $20^{\circ} \mathrm{C}$ na temperatura final) quando comparadas ao HLS2. 


\subsection{Temperatura do sistema de filtro térmico}

Durante os testes de irradiância deste protótipo resolvemos medir a temperatura do corpo do novo filtro térmico.

Verificamos que está temperatura após 60 minutos atingiu $42 \pm 1^{\circ} \mathrm{C}$, fato que descarta de vez a necessidade do sistema de troca da água.

\subsection{Temperatura na saída do filtro térmico}

Com relação à temperatura na saída do filtro podemos dizer que houve uma pequena alteração entre o valor medido no $\mathrm{HLS} 2,39 \pm 1^{\circ} \mathrm{C}$ e no $\mathrm{HLS} 342 \pm 1^{\circ} \mathrm{C}$. Entretanto é importante ressaltar que esta medida foi realizada próximo do ponto focal onde a irradiância é máxima. Os testes preliminares na distância de $5 \mathrm{~cm}$ do filtro térmico mostraram a diminuição da temperatura para cerca de $30 \pm 1^{\circ} \mathrm{C}$.

\subsubsection{Avaliação Estrutural do HLS3}

Após avaliação dos componentes notamos que o sistema se tornou robusto e confiável, sendo que todas as partes do protótipo foram construídas em alumínio, que é um material altamente durável e resistente a corrosão.

O protótipo HLS3 foi desmontado e montado diversas vezes $(n>10)$ e os componentes apresentaram perfeito encaixe.

Neste ponto ficamos satisfeitos com os resultados apresentados pelo protótipo descartando qualquer nova modificação neste trabalho. 


\subsection{Resultado do “Tecnology Road Map" (TRM)}

Como resultado da aplicação do TRM, temos uma mapa, que situa no tempo, características de mercado e negócios, características do produto e área de tecnologia, este mapa é o produto final da aplicação do processo T-Plan, que foi adaptado para o projeto de pesquisa. Não é objeto desse trabalho a análise deste processo de aplicação como um todo e sim o resultado final e suas conseqüências.

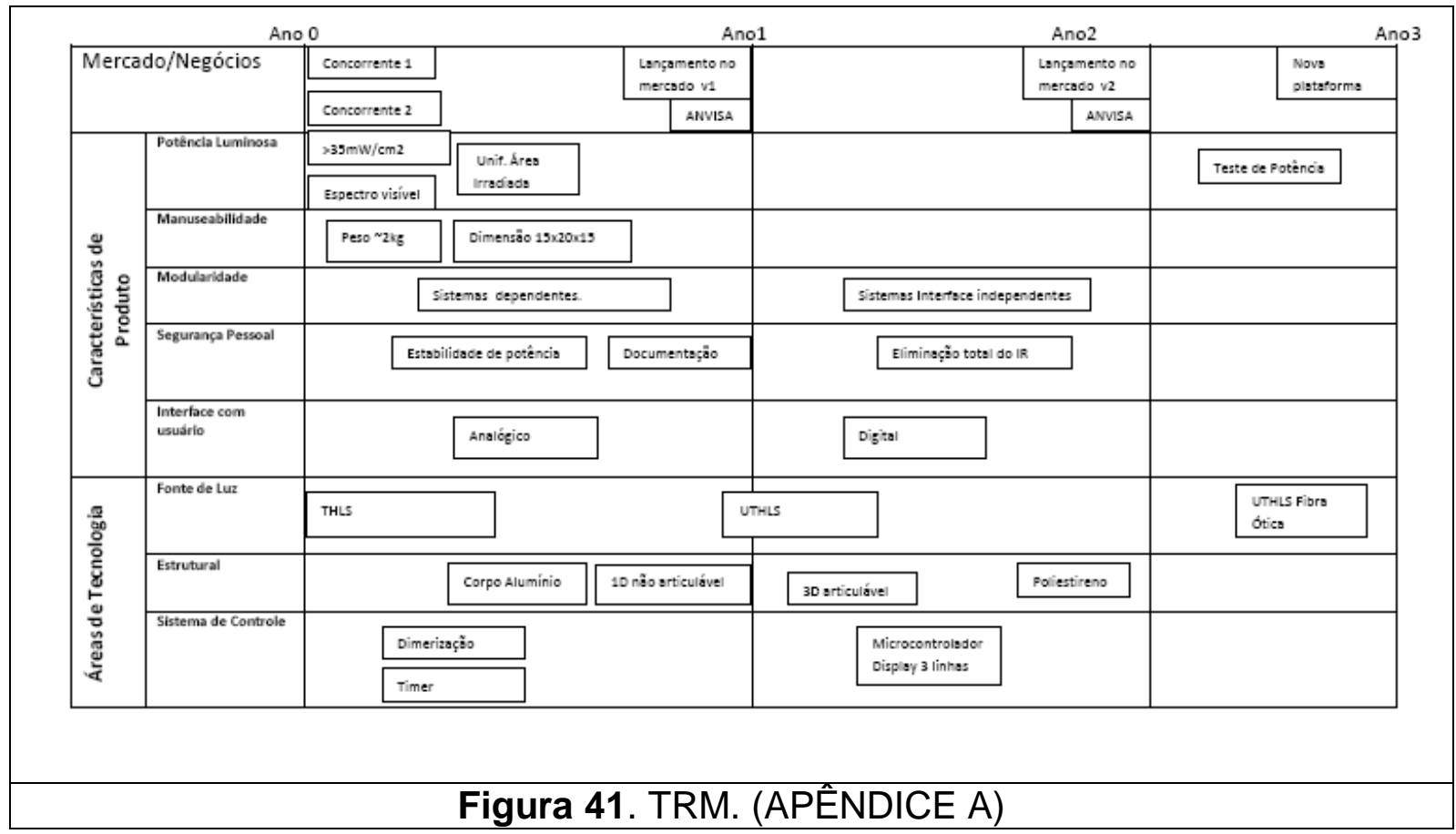

No capítulo seguinte faremos uma breve discussão sobre as vantagens da utilização deste método no desenvolvimento de um produto.

\subsection{Resultados do teste da aplicação invitro}

A seguir estão os primeiros resultados do teste do HLS3 in vitro. Neste teste monitoramos a fotocitotoxicidade do Photogem®, um fotossensibilizador aplicado 
clinicamente no tratamento do câncer, na cultura de células de adenocarcinoma de colo retal humano HT29, que são usados como padrão de testes de fotocitotoxicidade na Europa.

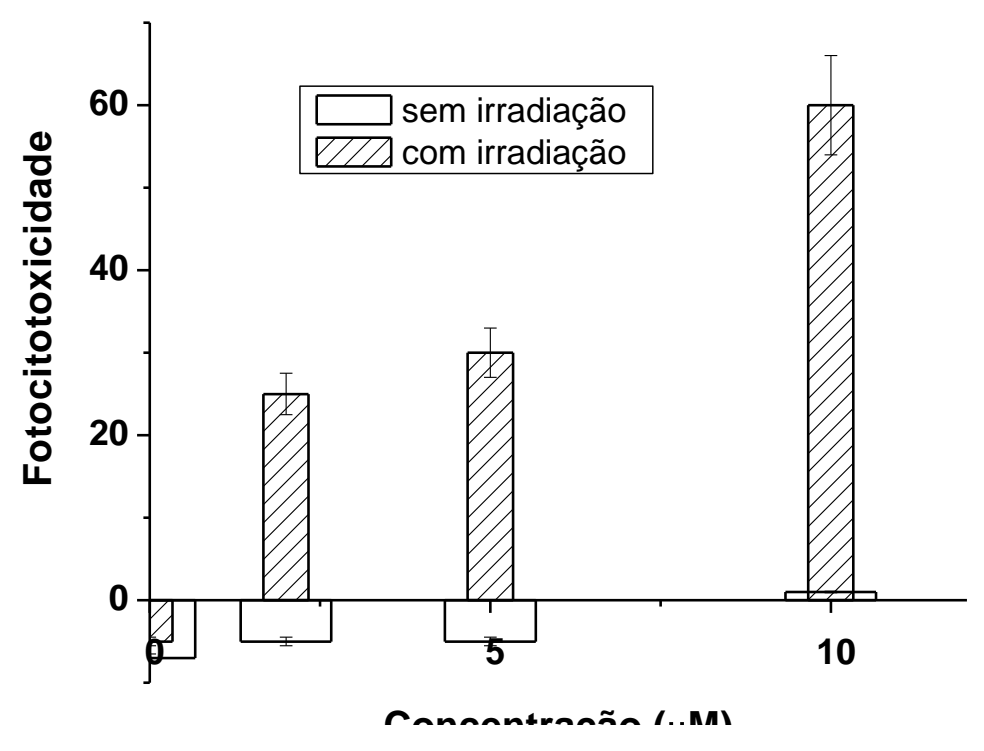

Figura 42. Fotocitotoxicidade do Photogem® em cultura de células de HT29.

O gráfico acima mostra os dados de fotocitotoxicidade do Photogem® contra as células de HT29 em função da concentração da droga, obtidos depois de 2 horas de incubação da droga no escuro e de 1 hora de irradiação pelo HLS3 com a posição da amostra na distância $15 \mathrm{~cm}$ do filtro térmico.

Como podemos observar nestes testes preliminares com HLS3 e o Photogem®, o HLS3 cumpriu seu papel ativando o fotossensibilizador e induzindo a morte celular. É importante lembrar que a morte celular poderia ter ocorrido pelo aquecimento, fato que fica descartado, pois a morte celular não ocorreu no grupo controle com ou sem fotossensibilizador e sem irradiação. 


\section{Capítulo 6 Discussão Final e Conclusões}

O objetivo deste trabalho foi o desenvolvimento de uma fonte luminosa baseada em lâmpadas halógenas que possa suprir as necessidades das aplicações fotobiológicas e fotomédicas, em especial em terapia fotodinâmica.

Além de potência adequada (irradiância) essa fonte deveria possuir mobilidade (fácil adaptação) para diferentes aplicações, ter um custo muito reduzido ao ser comparada com fontes de lasers e leds comerciais, bem como ser de fácil manuseio e de simples manutenção.

Tomando por base as características que determinamos para nossa fonte, vamos analisar individualmente as características obtidas com o protótipo HLS3.

\subsection{Irradiância}

Segundo x e y os valores típicos de irradiância para aplicações em terapia fotodinâmica cujo grau de exigência é alto, são necessários aproximadamente $50 \mathrm{~mW} / \mathrm{cm}^{2}$ (Morton et al., 2002; Grossweiner, 1997), de área tratada.

Analisando o gráfico $x$ temos que na saída do HLS3 temos um valor de irradiância de $484,25 \pm 14,53 \mathrm{~mW} / \mathrm{cm}^{2}$, ou seja, cerca 10 vezes maior do que o valor médio exigido por esta aplicação.

O fato de termos construído uma fonte cuja irradiância é cerca de uma ordem de grandeza maior, não é por acaso.

Este fato nos da à possibilidade de fazermos uma aplicação num menor tempo, o que reflete um maior conforto ao paciente, visto que o tempo de 
tratamento é reduzido e ainda como conseqüência ocasionar uma maior produtividade ao serviço. Torna possível também a utilização de filtros de cores, selecionando regiões do espectro em que os diferentes fotossensibilizadores, usados em PDT tenham maior absorção.

\subsection{Diversidade de Aplicações}

A diversidade de aplicações está intimamente ligada ao fato de que a emissão das lâmpadas halógenas, em especial a do HLS3, abrange uma grande faixa do espectro, dos 400 até $830 \mathrm{~nm}$, abrangendo toda região da janela terapêutica (600-800nm), onde os tecidos permitem uma maior penetração da luz.

O fato de termos emissão em uma grande faixa do espectro agrega a nossa fonte uma vantagem quando comparada a fontes baseadas em lasers e leds, que é possibilidade de trabalharmos com diferentes agentes fotossensibilizadores, visto que, em geral as regiões de maior absorção destes compostos não coincidem.

Com relação à área tratada novamente o HLS3 leva vantagem, pois pode garantir a irradiância média utilizada em PDT numa área relativamente grande. Como podemos observar nas figuras 37 e 38 a região irradiada satisfatoriamente teria cerca de $2 \mathrm{~cm}$ de raio resultando numa área tratada de $12,6 \mathrm{~cm}^{2}$.

\subsection{Custo}

Com relação ao custo, este é o ponto onde as fontes baseadas em lâmpadas halógenas mais se destacam, perante as demais. 
Este protótipo tem custo de materiais, incluindo a lâmpada em torno de $\mathrm{R} \$ 350,00$ (Trezentos e cinqüenta reais). Não vamos aqui incluir custos de produção, marketing, pesquisa,..., ou qualquer outro custo relacionado ao processo de desenvolvimento de produto, pois este, foge ao escopo deste trabalho.

No entanto podemos fazer algumas considerações a respeito do custo das fontes concorrentes. As fontes de lasers e leds convencionais nacionais têm custo estimado em $\mathrm{R} \$ 20.000,00$ (Vinte mil reais), para aparelhos produzidos no Brasil. Fica evidente a diferença de preço entre os diferentes tipos de fonte.

Neste ponto do trabalho, vamos fazer uma ressalva. São indiscutíveis as inúmeras aplicações de lasers e leds na vida moderna, o fato é estamos diante de um dilema. È sempre necessário utilizar esta tecnologia com alto valor econômico agregado?. A resposta dos testes iniciais com o HLS3 em terapia fotodinâmica, diz que não. No entanto devemos ser cautelosos, pois existem inúmeros testes a serem feitos antes de uma conclusão definitiva.

$\mathrm{Na}$ literatura já encontramos casos de aplicação de fontes baseadas em lâmpadas halógenas,como citado anteriormente, e atualmente temos até uma fonte aprovada pela agências reguladoras de produtos destinados a área médica americana (FDA) e européia (CE Medical) como é o caso do Lumacare® , más estudos que comparem a eficiência de um determinado tipo de fonte perante os demais praticamente não existem ou não são parte nosso conhecimento, até o presente momento. 


\subsection{Facilidade de Operação}

Em geral os diferentes tipos de fonte utilizados em terapia fotodinâmica, são de fácil operação, em muitos casos, basta selecionar a irradiância desejada e calcular o tempo para a aplicação de uma determinada dose, em outros a dose é selecionada diretamente.

No protótipo HLS3, estamos num estágio anterior, ou seja, temos uma curva de irradiância (Figura 37) que mostra os diferentes valores de irradiância para diferentes distâncias, a partir deste ponto, basta posicionar a região de interesse em determinada distância e calcular o tempo para a dose desejada.

\subsection{Manutenção}

Com relação à manutenção podemos dizer que cada tipo de fonte utilizado em terapia fotodinâmica, tem um determinado tipo de manutenção.

As fontes de laser necessitam de calibração periódica, o que aumenta os custos, pois geralmente essas fontes são importadas, quanto aos leds não temos informações sobre custos, no entanto, como a fonte em si é de alto custo, podemos supor que a manutenção também tenha custo elevado.

Quanto às fontes baseadas em lâmpadas halógenas, basta substituir a lâmpada, o que, torna o custo de manutenção relativamente baixo. 


\subsection{Tecnology Roadmap}

Os resultados do encontrados propiciaram para nós um planejamento estratégico simples, porém útil para localizar o produto dentro do mercado e estabelecer caminhos a serem seguidos no futuro durante um novo trabalho que continue esta pesquisa ou até mesmo na implantação deste produto em uma empresa que possa a vir produzi-lo. Esse fato contribuirá para que este produto tenha maiores chances de obter sucesso e se tornar um produto comercialmente viável.

Outro ponto importante é que a execução deste roadmap aconteceu em paralelo com, o desenvolvimento deste produto, fato que não é totalmente adequado. O roadmap deveria ter sido elaborado primeiro, pois ao analisar o mapa pronto, percebemos que poderíamos ter economizado tempo e recursos, pois o processo de elaboração do mapa definiu melhor quais características eram mais importantes e deveriam ter maior atenção neste produto.

\subsection{Conclusão Final}

Tomando base os resultados aqui apresentados, concluímos satisfatoriamente o objetivo principal que era desenvolver uma fonte luminosa baseada em lâmpadas halógenas para aplicações em fotobiologia e fotomedicina.

Partimos da teoria de do conceito e chegamos a um protótipo que apresenta as características adequadas para as aplicações que se destina. Muitos testes devem ser feitos antes de termos um produto pronto para comercialização, no 
entanto, a exploração destes testes e dos potenciais de aplicação deste produto poderão ser objetos de estudo de outro trabalho.

\section{Capítulo 7 Perspectivas}

Como os resultados preliminares de aplicação da terapia fotodinâmica utilizando o HLS3 como fonte e o Photogem® como fotossensibilizador foram positivos, devemos ampliar os testes como novos agentes fotossensibilizadores, novas linhagens de células e aplicações in vivo em animais, incluindo nestes testes outros tipos de fonte de modo a estabelecer uma comparação entre elas.

Devemos ainda incorporar novas funcionalidades ao HLS3, como sistema de controle de irradiância digital e controle de dose, assim como outras modificações que foram previstas no roadmap, como: aplicação de fibra ótica, controle eletrônico da dose, assim como tornar o sistema mais leve e articulado, etc.

Pretendemos ainda trabalhar com diferentes tipos de fontes, tais como as lâmpadas de xenônio, que permitem obter uma distribuição espectral muito próxima da luz do dia, e os leds brancos de alta potência, que pretendemos utilizar para desenvolver um irradiador para placas de cultura de células, onde cada loco da placa devera ser irradiado individualmente por cada led, criando uma irradiação uniforme através de toda placa, facilitando deste modo o trabalho de pesquisadores que necessitem irradiar as células de maneira uniforme, aproveitando o máximo de lócus disponíveis da placa. 
E por fim pretendemos estabelecer um comparativo sobre os diferentes tipos de fontes utilizados em fotoquimeoterapia de modo a determinar a real influência dessas fontes nos tratamentos de diferentes doenças.

\section{Capítulo 8 Referências}

- Albright R, Kappel T- Roadmapping in the Corporation. Research Technology Management, p. 31-40 (2003).

- ATCC disponível em: www.atcc.org TumorLines.pdf (2008).

- Birge RR, Computer 25 (11), 56-67 (1992).

- Bonnet R. - Chem. Soc. Rev. 19 (1995).

- Brown, S B; Brown, E A; Walker, I.-The present and future role of photodynamic therapy in cancer treatment - The Lancet Oncology, 5: 497508, (2004).

- Calvete M; Yang G Y; Hanack M -Syntetic Met. 141, 231 (2004).

- Clark K B, Wheelwright S C - Managing New Product and Process Development. New York: The Free Press, p. 751. (1993).

- Cooper R. Winning at New Products: Accelerating the Process from Idea to Launch. . Addison-Wesley Publish Enterprizy, p. 385. (1993).

- Cunderlíková B., Gangeskar L., MOAN J.- Photochem. Photobiol. B:Biol. 53 81 (1999).

- Dini D, Hanack M, Egelhaaf HJ, Sancho-Garcia JC, Cornil J, J Phys Chem B 109 (12) 5425 (2005). 
- Dougherty T. J. -Photodynamic therapy- Photochem. Photobiol. 58 895-900 (1993).

- Dougherty TJ, Kaufman JE, Goldfarb A, Weishaupt KR, Mittleman A; Cancer Res. 38, 2628 (1978)

- Foote, C.S. - Definition of Type I and Type II photosensitized oxidationPhotochemistry and Photobiology, 54(5): 659, (1991).

- Garcia M L ; Bray, O. H. Funndamentals of Technology Roadmapping.Sandia National Laboratories. (1997).

- Grossweiner LI - PDT light dosimetry revisited - Journal of Photochemistry and Photobiology - B:Biology 38 (1997) 258-268;

- Hammer-Wilson M.J., Akian L., Espinosa J., Kimel S., Berns M.W. Photochem. Photobiol. 5344 (1999).

- Henderson, B. W.; Dougherty, T. J. - How does photodynamic therapy work? - Photochemistry Photobiology, 55: 145 - 157, (1992).

- Ito AS, Tardivo JP,et al. - Treatment of lesions using methylene blue and RL50 light source - Photodiagnosis and Photodynamic Therapy - (2004) 1, 3445-346;

- Kothapalli SR, Wu PF, Yelleswarapu CS, Rao DVGLN, Appl Phys Lett 85 (24): 5836 (2004).

- Lang K., Mosinger J., Wagnerova D.M. - Chem. Rev. 248-321 (2004).

- Lee G, Chu K, Conroy L, Fix L, Lui G, Truesdell C - A study of Biophotonics - Optik \& Photonik (2) 30-35 (2007). 
- Levy J. G.; Chowdhary R. K. - Immune modulation using transdermal photodynamic therapy- Proceedings of SPIE 2325155 (1995).

- Liu MO, Tai CH, Hu AT, Wei TH, J Organomet Chem, 689 (12): 2138-2143 (2002).

- Loppacher C, Guggisberg M, Pfeiffer O, Meyer E, Bammerlin M, Lüthi R, Schlittler R, Gimzewski JK, Tang H, Joachim C; Phys. Rev. Lett. 90, 066107-1 (2003).

- Lumacare disponível em www.lumacare.com (2008);

- Martins F. R.; Pereira E. B.; Echer M. P.- Rev. Bras. Ens. Fis. 26 (2004).

- Morton CA, Brown SB, et al. - Guidelines for tropical photodynamic therapy British Journal of Dermatology -(2002);146: 552-567;

- Mosmann T. J. Immunol. Methods, 65, 55-63 (1983).

- Neto P M - Planejamento de Novos Produtos por Intermédio do Método Technology Roadmapping (TRM) em uma Pequena Empresa de Base Tecnológica do Setor de Internet Móvel. Dissertação de Mestrado. Departamento de Engenharia de Produção - UFMG - Belo Horizonte. (2005).

- Ochsner M. - Photophysical and photobiological processes in the photodynamic therapy of tumours-, J. Photoch. Photobiol. B: Biology 39 1-18 (1997).

- Osran -www.osran.com.br-OSRAM_catalogo07_halogenas.pdf (2008).

- Phaal R; et al.-Starting-up Roadmapping Fast - Research Technology Management, p. 52-58. (2003). 
- Philips - www.philips.com.br- ALR.pdf (2008).

- PucRio disponível em: http//www2.dbd.pucrio/pergamun/tesesabertas/0421327 06 cap03.pdf (2008)

- Rozenfeld H, et al.- Gestão de Desenvolvimento de Produtos - Uma referência para a melhoria do processo. São Paulo: Saraiva. (2006)

- Schuitmaker, J.; Bass, P.; Van, Leengoed, H.L.L.M.; Van der Meulen, F.W.; Star, W.M.; Van Zandwijk, N. J.- Photochem. Photobiol. B: Biol. 343 (1996).

- Rutgers diponivel em: http://marine.rutgers.edu/cool/education/class/josh/black body.html (2008)

- Scientific American - vol 26 - Jan 2003;

- Sliney D H - Radiometric Quantities and Units used in Photobiology and Photochemistry: Recommendations of International Comission on Illumination-Photochemistry and Photobiology, 83 425-432 (2007).

- Souza G. L.-Radiação de Corpo Negro- Centro de Referência para o Ensino de Física Instituto de Física UFRGS (2001).

- Spectra Physics - manual part number H0407-1030 rev.F - (1997).

- Stuart J A, Marcy D L, Wise K J, Birge R R, Synthetic Met 127, 3-15 (2002).

- Turro N J - Modern Molecular Photochemistry- University Science Books NYork (1991).

- Whalen PJ - Strategic and Technology Planning on a Roadmapping Foundation - Research Technology Management, v. 50, p. 40. (2007).

- Wu P F, Bhamidipati M, Coles M, Rao DVGLN, Chem Phys Lett 400 (4-6) 506510 (2004). 
- Yang G, Li Y, Dreger ZA, White JO, Drickamer HG, Chem Phys Lett 280 (34): 375 (1997).

- Zheng G., Potter W.R., Sumlin A, Dougherty T.J., Pandey R.K. - Biorg. \& Med. Chem. Lett. 10123 (2000). 


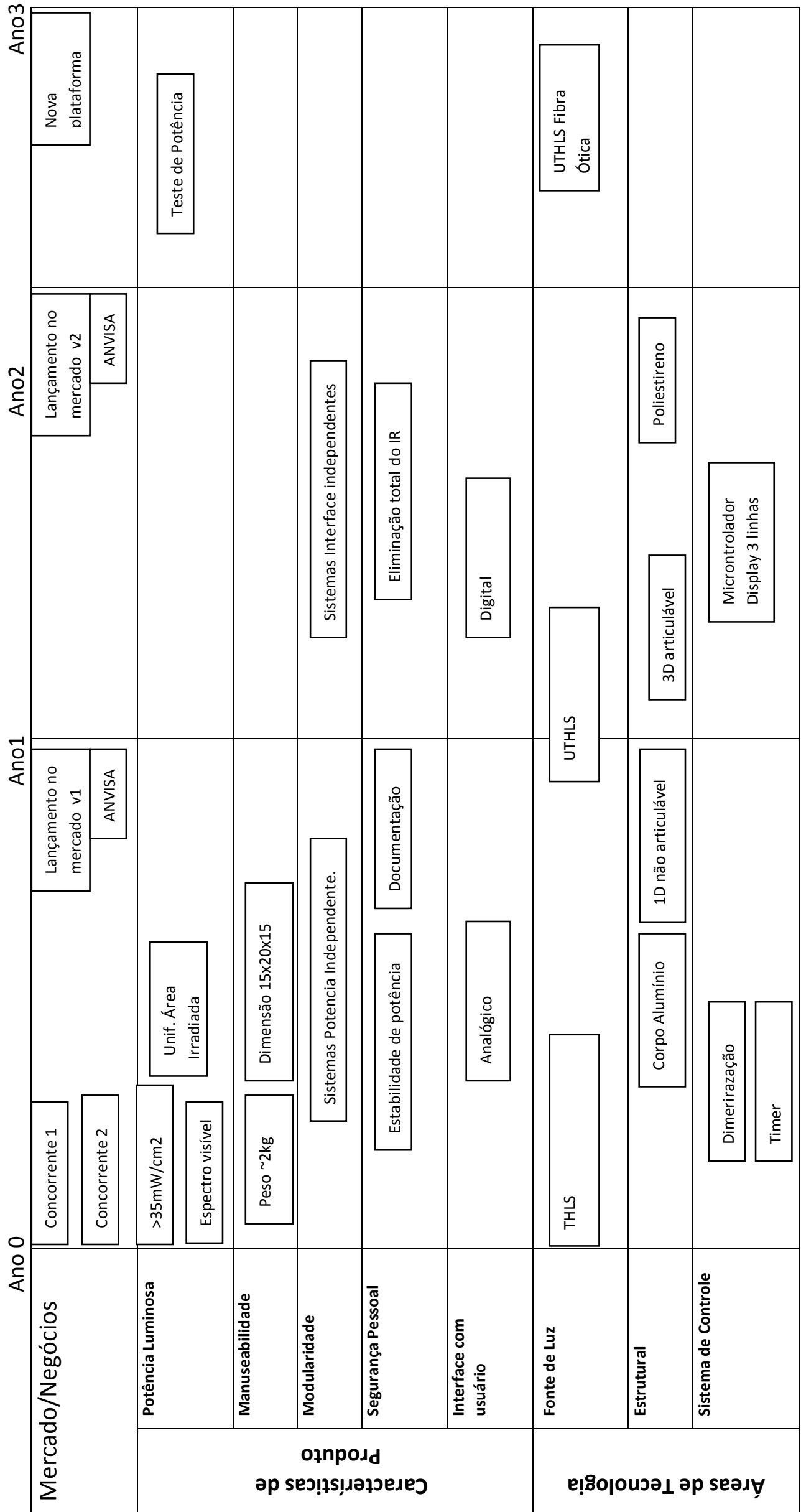

